Florida International University

FIU Digital Commons

FIU Electronic Theses and Dissertations

University Graduate School

$10-27-2011$

\title{
Disease and Hygiene in the Construction of a Nation: The Public Sphere, Public Space, and the Private Domain in Buenos Aires, 1871-1910
}

Kindon T. Meik

Florida International University, kindonmeik@gmail.com

DOI: $10.25148 /$ etd.FI1 1120805

Follow this and additional works at: https://digitalcommons.fiu.edu/etd

\section{Recommended Citation}

Meik, Kindon T., "Disease and Hygiene in the Construction of a Nation: The Public Sphere, Public Space, and the Private Domain in Buenos Aires, 1871-1910" (2011). FIU Electronic Theses and Dissertations. 547.

https://digitalcommons.fiu.edu/etd/547

This work is brought to you for free and open access by the University Graduate School at FIU Digital Commons. It has been accepted for inclusion in FIU Electronic Theses and Dissertations by an authorized administrator of FIU Digital Commons. For more information, please contact dcc@fiu.edu. 


\title{
FLORIDA INTERNATIONAL UNIVERSITY
}

Miami, Florida

\section{DISEASE AND HYGIENE IN THE CONSTRUCTION OF A NATION: THE PUBLIC SPHERE, PUBLIC SPACE, AND THE PRIVATE DOMAIN IN BUENOS AIRES, 1871-1910}

\author{
A dissertation submitted in partial fulfillment of the \\ requirements for the degree of \\ DOCTOR OF PHILOSOPHY \\ in \\ HISTORY \\ by
}

Kindon Thomas Meik 
To: $\quad$ Dean Kenneth G. Furton

College of Arts and Sciences

This dissertation, written by Kindon Thomas Meik, and entitled Disease and Hygiene in the Construction of a Nation: The Public Sphere, Public Space, and the Private Domain in Buenos Aires, 1871-1910, having been approved in respect to style and intellectual content, is referred to you for judgment.

We have read this dissertation and recommend that it be approved.

Noble David Cook

Patricia L. Price

Victor M. Uribe-Uran

Mark D. Szuchman, Major Professor

Date of Defense: October 27, 2011

The dissertation of Kindon Thomas Meik is approved.

Dean Kenneth G. Furton

College of Arts and Sciences

Dean Lakshmi N. Reddi

University Graduate School

Florida International University, 2011 


\section{DEDICATION}

This dissertation is dedicated to my children Riley, Morgan, Alice, Abbi, Grant, and Ava. Most important, this work is dedicated to my wife and best friend, Angie. 


\section{ACKNOWLEDGMENTS}

The ideas developed in the present work originated from the various reading assignments and discussions associated with the courses taught by N. David Cook, Sherry Johnson, Patricia Price, Mark Szuchman, and Victor Uribe at Florida International University. I am indebted to their instruction and benefited from the encouragement they provided. Without question, the completion of the dissertation would not have been possible without the continual patience and guidance of Dr. Szuchman. He has been a benevolent mentor and a wise teacher. A special thank you is necessary for the librarians of the Biblioteca Municipal de Buenos Aires who provided invaluable help in locating pertinent information and primary sources. Similarly, the faculty and inter-library loan staff at California State University Bakersfield were likewise supportive and made it possible to secure needed texts and other documents. Finally, I wish to recognize my wife, Angie, who sees my potential and overlooks my weaknesses. Her many sacrifices as a result of my endeavors will always be appreciated. 


\section{ABSTRACT OF THE DISSERTATION \\ DISEASE AND HYGIENE IN THE CONSTRUCTION OF A NATION: \\ THE PUBLIC SPHERE, PUBLIC SPACE, AND THE PRIVATE DOMAIN IN BUENOS \\ AIRES, 1871-1910}

by

Kindon Thomas Meik

Florida International University, 2011

Miami, Florida

Professor Mark D. Szuchman, Major Professor

The maturation of the public sphere in Argentina during the late nineteenth and early twentieth centuries was a critical element in the nation-building process and the overall development of the modern state. Within the context of this evolution, the discourse of disease generated intense debates that subsequently influenced policies that transformed the public spaces of Buenos Aires and facilitated state intervention within the private domains of the city's inhabitants. Under the banner of hygiene and public health, municipal officials thus Europeanized the nation's capital through the construction of parks and plazas and likewise utilized the press to garner support for the initiatives that would remedy the unsanitary conditions and practices of the city. Despite promises to the contrary, the improvements to the public spaces of Buenos Aires primarily benefited the porteño elite while the efforts to root out disease often targeted working-class neighborhoods. The model that reformed the public space of Buenos Aires, including its socially differentiated application of aesthetic order and public health policies, was ultimately employed throughout the Argentine Republic as the consolidated political elite rolled out its national program of material and social development. 
TABLE OF CONTENTS

CHAPTER PAGE

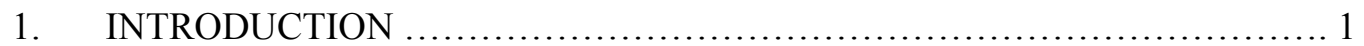

2. YELLOW FEVER AND THE PUBLIC SPHERE ......................... 12

The Theoretical Nature of the Public Sphere ...................................................... 13

Disease and Hygiene in Buenos Aires ........................................................... 23

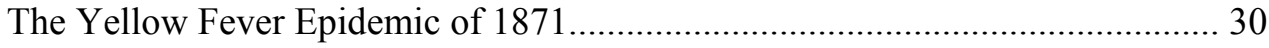

The Porteño Press and the Comisión de la Salud Pública ................................... 48

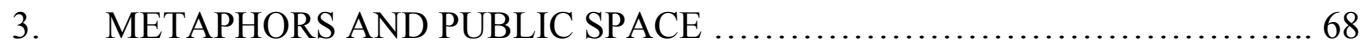

Metaphors of the Body, Metaphors of Civilization .......................................... 73

The Parque 3 de Febrero and the Jardín Zoologico ............................................ 84

4. GUARDIANS OF THE PUBLIC HEALTH AND THE PRIVATE DOMAIN..100

The Higienistas and the Dirección General de la Asistencia Pública ................ 103

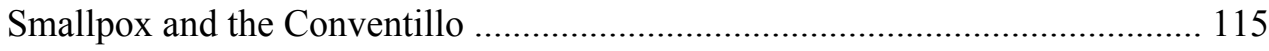

5. CONCLUSIONS................................................. 132

LIST OF REFERENCES .................................................. 143

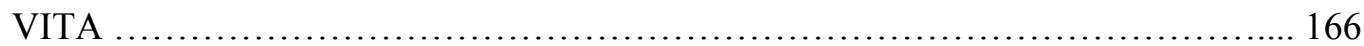




\section{CHAPTER 1}

Introduction

The evolution of the public sphere in Argentina following independence was a fundamental aspect of the nation-building process and therefore a critical component in the transition from nascent republic to modern state. Accordingly, the public sphere constitutes an essential element of historical understanding especially when juxtaposed with the equally relevant constructs of public space and the private domain. The convergence of the public sphere, public space, and the private domain establishes a useful analytical lens with which it is possible to observe that changes in one simultaneously influenced the others and consequently altered the dynamics of state-society relations. Nowhere was this more evident than in the discourse of disease and public health prevalent during Argentina's famed belle époque period that spanned the late nineteenth and early twentieth centuries. Within the context of modernization, this study will analyze the transformation of the public sphere in Buenos Aires between 1871 and 1910. In doing so, special attention will be given to the rhetoric of hygiene and progress that prompted a reconfiguration of the city's public spaces and led to the creation of institutions that encroached upon the private lives of porteños.

The theoretical framework of the public sphere is found in the writings of the German philosophers, Reinhart Kossellek and Jürgen Habermas. ${ }^{1}$ In their respective studies, Koselleck

\section{Reinhart Koselleck, Critique and Crisis: Enlightenment and the Pathogenisis of Modern} Society (Cambridge: MIT Press, 1988); Jürgen Habermas, The Structural Formation of the Public 
and Habermas argued that the formation and development of the public sphere in England, France, and Germany during the seventeenth and eighteenth centuries was a result of the changing relationship between civil society and the state. Of particular interest was the increased consumption of printed material by a bourgeois reading public and the creation of an "interacting body of citizens engaged in rational-critical discourse." Within this "network of communication," the public "generated its own 'universal' moral standards through the communicative process, and eventually applied those standards critically to the state and its policies." 3 In short, the public sphere created a forum in which individuals could meet and discuss issues of public interest and formulate collective responses to the policies of the ruling elite.

Intrinsically linked to the development of the public sphere was the appearance of new forms of sociability and the appropriation of physical spaces in which people could "gather, use their reason, and ultimately mold 'public opinion."'4 In many ways, these spaces—cafés, plazas, marketplaces, lodges, and other settings — became the physical embodiment of the public sphere. In this regards,

The urban milieu offers an intriguing site for the historian interested in exploring changing relations of power, class, conflict, opposing visions of the future, breakdowns

Sphere: An Inquiry Into a Category of Bourgeois Society, Thomas Burger (Cambridge: MIT Press, 1989).

2. Craig Calhoun, "Civil Society of Public Life," Contemporary Sociology 19, no. 2 (1990): 313.

3. Anthony J. La Vopa, "Conceiving a Public: Ideas and Society in Eighteenth-Century Europe," The Journal of Modern History 64, no. 1 (March 1992): 99.

4. Victor M. Uribe-Uran, "The Birth of a Public Sphere in Latin America During the Age of Revolution," Comparative Studies in Society and History 42, no. 2 (April 2000): 437. 
of social order, gendered spaces, health and disease, visual culture, spectacle and symbolic codes, and ultimately the creation of community. ${ }^{5}$

As an extension of the public sphere, public spaces are thus "nodes of communication" that are essential in the "ebb and flow of human exchange." Furthermore, like the public sphere, public spaces became contested arenas that acquired meaning through their use and function. ${ }^{6}$

Finally, as pointed out by Habermas, the development of a public sphere occurred in conjunction with and parallel to the emergence of a private sphere. In fact, similar to the development of the public sphere, Roger Chartier asserts that the creation of a private sphere was a "necessary condition" in the formation of the modern state. ${ }^{7}$ Far from being independent, the public sphere and the private domain often overlapped. ${ }^{8}$ For Philippe Ariès this convergence was especially noticeable in those areas where the activities of the individual and subsequently the family were carried out in the "state's shadow." With this understanding, Chartier concedes that

5. Anthon Rosenthal, "Spectacle, Fear, and Protest: A Guide to the History of Urban Public Space in Latin America," Social Science History 24, no. 1 (2000): 34.

6. Stephen Carr, Public Space (Cambridge: Cambridge University Press, 1992), 3, 22-23 See also Setha Low, On the Politics of Public Space (Austin: University of Texas Press, 2000).

7. Roger Chartier, ed., A History of Private Life: Passions of the Renaissance, A History of Private Life (Cambridge, Mass.: Belknap Press of Harvard University Press, 1987).

8. Deena Goodman, "Public Sphere and Private Life: Toward a Synthesis of Current Historiographical Approaches to the Old Regime," History and Theory 31, no. 1 (February 1992): 1-20; Sara Maza, "Domestic Melodrama as Political Ideology: The Case of the Comte de Sanois," American Historical Review 94, no. 5 (December 1989): 1249-64.

9. Philippe Ariès, Passions of the Renaissance, A History of Private Life (Cambridge, Mass.: Belknap Press of Harvard University Press, 1988), 2. 
the "limits of the private sphere depend primarily on the way public authority is constituted." 10

My study proceeds on the premise that the public sphere in Argentina first appeared in the late eighteenth century. Moreover, as was the case with other regions of Spanish America, the public sphere matured during the revolutionary period and continued to expand in the decades following independence. ${ }^{11}$ Despite the wealth of scholarly potential, literature on the public sphere in Argentina remains relatively scant. ${ }^{12}$ The same argument can be made about the historiography on the private domain. ${ }^{13}$ In contrast, the porteño public space as a topic of

\section{Philippe Ariès, Passions of the Renaissance, 15.}

11. Uribe-Uran, “The Birth of a Public Sphere,” 425-26 See also Pilar González Bernaldo de Quirós, “La Revolución Francesa y la emergencia de nuevas prácticas de la política: La irrupción de la sociabilidad política en el Río de la Plata revolucionario, 1810-1815," in La Revolución Francesa y Chile, ed. Ricardo Krebs and Christián Gazmuri (Santiago de Chile: Editorial Universitaria, 1990), 111-35. In contrast to the notion that a public sphere was developing prior to the 1850 s see Hilda Sábato, "Citizenship, Political Representation and the Formation of the Public Sphere in Buenos Aires, 1850s-1880s," Past and Present 136 (1992): 139-63.

12. In addition to those already cited see Ariel de la Fuente, Children of Facundo: Caudillo and Gaucho Insurgency During the Argentine State-Formation Process (Durham: Duke University Press, 2000); Ariel de la Fuente, "Facundo and Chacho in Songs and Stories: Oral Culture and the Representations of Caudillos in the Nineteenth-Century Interior," Hispanic American Historical Review 80, no. 3 (August 2000): 503-35; Juan Carlos Gravaglia, "Elecciones y luchas póliticas en los pueblos de la campaña de Buenos Aires: San Antonio de Areco," Boletín del Instituto de Historia Argentina y Americana “Dr. Emilio Ravagnani, no. 27 (1er semestre 2005): 49-74.

13. Mark D. Szuchman, Order, Family, and Community in Buenos Aires: 1810-1860 (Stanford: Stanford University Press, 1988); Jeffrey M. Shumway, The Case of the Ugly Suitor and Other Histories of Love, Gender, and Nation in Buenos Aires, 1776-1870 (Linoln: University of Nebraska Press, 2005). 
academic interest has perhaps received the most attention. ${ }^{14}$ Notwithstanding, these subjects are often treated independently thus causing a historiographical rift in the literature. ${ }^{15}$

In an effort to bridge the intellectual divide identified above, the present discussion relies on the discourse of disease and hygiene to highlight the symbiotic relationship between the public sphere, public space and the private domain. Scholarly research on disease as it relates to the history of the Americas can be traced to the mid-twentieth century when academic inquiries first analyzed the destructive effects of Old World contagions on Amerindian populations during

14. James R. Scobie, Buenos Aires: From Plaza to Suburb, 1870-1910 (New York: Oxford University Press, 1974); Jeffrey D. Needell, "Rio de Janeiro and Buenos Aires: Public Space and Public Consciousness in Fin-De-Siècle Latin America," Comparative Studies in Society and History 37, no. 3 (July 1995): 519-40; Adrián Gorelik, La grilla y el parque: espacio público y cultura urbana en Buenos Aires, 1887-1936 (Buenos Aires: Universidad Nacional de Quilmes, 1998); Sonia Berjman, "Los espacios verdes de Buenos Aires entre 1880 y 1925” (Ph.D. diss., Buenos Aires: Facultad de Filosofía y Letras, Universidad de Buenos Aires, 1987); Sonia Berjman, Plazas y parques de Buenos Aires: La obra de los paisajistas franceses (Buenos Aires: Fondo de Cultura Económica, 1998); Diego Armus, "La idea del verde en la ciudad moderna: Buenos Aires, 1870-1940," Entrepasados 5, no. 10 (1996): 9-22; Mark D. Szuchman, "Constructing the City, Constructing the State: Architecture and Political Transition in Urban Argentina, 1810-1860," in State and Society in Spanish America During the Age of Revolution, ed. Victor M. Uribe-Uran (Wilmington, Delaware: Scholarly Resources Inc., 2001), 193-218; Elisa Radovanovic, Buenos Aires: Ciudad Moderna, 1880-1910 (Buenos Aires: Ediciones Turisticas de Mario Banchik, 2002); Elisa Radovanovic, Buenos Aires: Avenida de Mayo (Buenos Aires: Ediciones Turísitcas de Mario Banchik, 2002).

15. Noticeable exceptions include Szuchman, Order, Family, and Community; Mark D. Szuchman, "Childhood Education and Politics in Nineteenth-Century Argentina: The Case of Buenos Aires," Hispanic American Historical Review 70, no. 1 (February 1990): 109-38. 
colonization. ${ }^{16}$ At its core, this body of literature challenged the widely accepted theory that Spanish cruelty accounted for the demise of Amerindian empires and instead attributed the collapse of native societies to epidemic diseases. ${ }^{17}$ Not surprisingly, the quincentenary of Columbus' encounter was marked by a surge of publications further highlighting the demographic and social ramifications associated with European expansion. ${ }^{18}$ Additionally,

16. See for example John Duffy, "Smallpox and the Indians in the American Colonies," Bulletin of the History of Medicine 25 (1951): 324-41; John Duffy, Epidemics in Colonial America (Baton Rouge: Louisiana State University Press, 1953); Alfred W. Crosby, "Conquistador y Pestilencia: The First New World Pandemic and the Fall of the Great Indian Empires," Hispanic American Historical Review 47 (1967): 321-37; Alfred W. Crosby, The Colombian Exchange: Biological and Cultural Consequences of 1492 (Westport, CT: Greenwood Press, 1972). A synthesis of the literature on disease as it relates to Colonial America can be found in Noble David Cook, Born to Die: Disease and New World Conquest, 1492-1650 (Cambridge: Cambridge University Press, 1998).

17. A summary of the bibliographic contributions can be found in William M. Denevan, "Native American Populations in 1492: Recent Research and a Revised Hemispheric Estimate," in The Native Populations of the Americas in 1492, ed. William M. Denevan (Madison: University of Wisconsin Press, 1992), xvii-xxxviii and in Noble David Cook and W. George Lovell, "Unraveling the Web of Disease," in The Secret Judgments of God: Native Peoples and Old World Disease, ed. Noble David Cook and W. George Lovell (Norman: University of Oklahoma Press, 1992), 215-44.

18. Thomas M. Whtimore, Disease and Death in Early Colonial Mexico: Simulating Amerindian Depopulation (Boulder, CO: Westview Press, 1992); Suzanne Austin Alchon, Native Society and Disease in Colonial Ecuador (Cambridge: Cambridge University Press, 1992); W. George Lovell, Conquest and Survival in Colonial Guatemala: A Historical Geography of the Cuchumatán Highlands, 1500-1821 (Montreal and Kingston: McGill-Queen’s University Press, 
scholarship of the period looked at the implications of disease in the late colonial period and the ideological and institutional changes in medical practices and public health measures. ${ }^{19}$

The themes of hygiene and public health as a reaction to disease continue to be relevant subjects in the historiography on Latin America. Of particular interest in academic discussions is the way in which public health played into the modernization and nation-building initiatives that characterized the late nineteenth and early twentieth centuries. Noteworthy contributions in this area concentrate primarily on the politics of public health and the unsanitary conditions that often altered "relations of production." 20 Though this focus continues to shape the historiography,

1992); David T. Reff, Disease, Depopulation, and Culture Change in Northwestern New Spain, 1518-1764 (Salt Lake City: University of Utah Press, 1991); Robert H. Jackson, Indian Population Decline. The Missions of Northwestern New Spain, 1687-1840 (Albuquerque: University of New Mexico Press, 1994).

19. Marcelo Frías Núñez, Enfermedad y sociedad en la crisis colonial del antiguo régimen Nueva Granada en el transito del siglo XVIII al XIX: las epidemias de viruela (Madrid: Consejo Superior de Investigaciones Científicas, 1992).

20. Diego Armus, ed., Disease in the History of Modern Latin America: From Malaria to AIDS (Durham, NC: Duke University Press, 2003), 4. Specific examples include Christopher Abel, Health, Hygiene and Sanitation in Latin America, 1870-1950 (London: University of London, 1996); Juan César García, “La medicina estatal en América Latina (1880-1930),” Revista Latinoamericana de Salud I (1981): 70-110; Claudia Agostina, Monuments of Progress: Modernization and Public Health in Mexico City, 1876-1910 (Calgary: University of Calgary Press, 2003); Mirta Zaida Lobato, Política, médicos y enfermedades: Lecturas de historia de la salud Argentina (Buenos Aires: Editorial Biblos, 1996); Ricardo González Leandri, Curar, persuadir, gobernar: La construcción histórica de la profesión médica en Buenos Aires, 18521886 (Madrid: Consejo Superior de Investigaciones Científicas, 1999); Héctor Recalde, La salud de los trabajadores en Buenos Aires (1870-1910) (Buenos Aires: Grupo Editor Universitario, 
recent studies have shifted away from the structuralist approach and have instead emphasized the socio-cultural aspects of disease and hygiene. ${ }^{21}$

The 1871 yellow fever epidemic in Buenos Aires and the subsequent demographic, social, and political changes that it fostered offers a special opportunity to analyze the nature and importance of the public sphere and the way in which the discourse of disease and public health telescoped into changes in the city's public spaces and in the private domain. As such, the epidemic of 1871 was "particularly important, not only because of its consequences but also because it pushed to the forefront the public's concern on issues of sanitation." ${ }^{22}$ Despite its relevance, literature on the yellow fever epidemic of 1871 is limited. Moreover, scholarly analysis on the outbreak in the last 140 years has focused almost exclusively on the demographic

1997).

21. Marcos Cueto, ed., Salud, cultura y sociedad en América Latina (Washington, D.C.: Organización Panamericana de la Salud, 1996); Marcos Cueto, El regreso de las epidemias: Salud y sociedad en el Perú del siglo XX (Lima: Instituto de Estudios Peuranos, 1997); Diego Armus, ed., Entre médicos y curanderos: cultura, historia y enfermedad en la América Latina (Buenos Aires: Grupo Editorial Norma, 2002); Diego Armus, La ciudad impura: Salud, tuberculosis y cultura en Buenos Aires, 1870-1950 (Buenos Aires: Edhasa, 2007); Katherine Bliss, “The Science of Redemption: Syphilis, Sexual Promiscuity, and Reform in Revolutionary Mexico," Hispanic American Historical Review 79, no. 1 (February 1999): 1-40; Carlos Contrera Cruz, "Ciudad y salud en el Porfiriato: La política urbana y de saneamiento de Puebla, 18801906,” Siglo XIX 1, no. 3 (1992): 55-76; Teresa Meade, “Civilizing” Rio: Reform and Resistance in a Brazilian City, 1889-1930 (University Park: Pennsylvania State University Press, 1997).

22. Ricardo González Leandri, Curar, persuadir, gobernar: La construcción histórica de la profesión médica en Buenos Aires: 1852-1886 (Madrid: Consejo Superior de Investigaciones Científicas, 1999), 85. 
ramifications of the disaster. ${ }^{23}$ Breaking from that trend, Miguel Angel Scenna's study on the epidemic touches on themes relevant to the public sphere but fails to go beyond $1871 .{ }^{24}$ More recently, the works of Jorge Salessi and Ricardo González Leandri use the epidemic as point of departure to discuss criminology and the development of a professional medical body, respectively. ${ }^{25}$ Salessi by far does the best in connecting the epidemic to the nation-building process of the late nineteenth century by analyzing the way in which the medical elite of the period returned to the texts written during the outbreak to show that the hygiene movement was in essence a result of "public opinion" and akin to the revolutionary movement that secured Argentine independence. ${ }^{26}$

The rhetoric of disease and hygiene as it influenced the public sphere, public space, and the private domain is examined in the three chapters that follow. The first will consider the vitality of the public sphere during the yellow fever epidemic in Buenos Aires in 1871. Throughout the disaster, the Buenos Aires press played an instrumental role in shaping public opinion and positioned itself as the defender of public liberties and the protective voice for the people's well-being. In so doing, the press directed its attention to the city's unsanitary conditions

23. José Penna, "Estudio sobre las epidemias de fiebre amarilla en el Río de la Plata," Anales del Departamento Nacional de Higiene 1, no. Año V (Noviembre 1895)Buenos Aires; Ismael Bucich Escobar, Bajo el horror de la epidemia: Escenas de la fiebre amarilla de 1871 en Buenos Aires (Buenos Aires, 1932); Leandro Ruiz Moreno, La peste histórica de 1871: Fiebre amarilla en Buenos Aires y Corrientes (Paraná, Argentina: Nueva Impresora, 1949).

24. Míguel Angel Scenna, Cuando murió Buenos Aires, 1871 (Buenos Aires: Ediciones La Bastilla, 1974).

25. Jorge Salessi, Médicos maleantes y maricas. Higiene, criminología, y homosexualidad en la construcción de la nación Argentina (Buenos Aires: 1871-1914) (Buenos Aires: Beatríz Viterbo Editora, 1995); González Leandri, Curar, persuadir, gobernar.

26. Salessi, Médicos maleantes y maricas, 27-47. 
and criticized municipal and state authorities for their inadequate responses during the epidemic. Rallying behind the voice of the press, porteños formed a loosely aligned organization to provide medical treatment and services to the city's poor. However, party loyalties and the personalist politics of the period proved stronger than the bonds of charity and the popular commission vanished nearly as quickly as it had appeared. As a result of the epidemic of 1871 , the subject of disease was infused into the discourse of modernization and remained a salient theme in the porteño press in the decades that followed. Concerned that Buenos Aires would continue to be plagued by repeated epidemics, the press advocated for public infrastructure projects to improve the hygienic condition of the city.

Chapter 2 examines the transformation of the urban landscape in Buenos Aires as new parks, plazas, and other public spaces became the metaphorical lungs of the metropolis. Beyond the benefits of health, public opinion insisted that the urban green spaces be modeled after the squares of London and the promenades of Paris thus erasing the colonial façade of the city. In this regards, the political elite also hoped that the physical modernization of the city would translate into changes in the public conscience and thereby assist in the creation of an Argentine identity.

With the reconfiguration of the urban public spaces, municipal authorities turned their attention to the private domain and the obstacles therein that inhibited progress. As such, the final chapter will analyze the discourse that shaped the public sphere as the governing elite extended its influence into the homes of porteños. Of particular concern to the hygienists of the period were the conventillos or tenements that housed the city's poor. In their efforts to limit the spread of disease, medical practitioners and health inspectors sent into the conventillos were met with resistance and were often frustrated in carrying out their endeavors.

In matters of disease and hygiene, the people's demand for government action was an indicator of the maturing character of the public sphere. As such, Buenos Aires became one of the earliest metropolitan areas of Latin America where public opinion exerted an influential effect on government policies that in turn directed the transformation of public space and redefined the 
activities within the private domain. The effects on the public sphere, public space, and the private domain as result of the discourse of disease and public health provide a unique case study for understanding vital aspects of the formation of modern states in Latin America. The applicability of this study thus ranges well beyond the municipal boundaries of this center of Spanish America's trans-Atlantic commerce and cultural exchange during the export-led boom. Moreover, this study will offer a significant empirical component to the body of theory on the increasingly complex relationship between state and society in this vital period of development. 


\section{CHAPTER 2}

Yellow Fever and the Public Sphere

Introduction

The public sphere in Latin America has historically been a contested space in which different groups have struggled for consideration and supremacy. Traditionally understood as the domain where public opinion is conceived, defined, and disseminated the public sphere is recognized as a fundamental element of modern societies. Moreover, the public sphere is dynamic and at times even volatile and as such it serves as a useful analytical tool in the examination of the nation-building process. It is within the context of Argentina's changing public sphere that the yellow fever epidemic of 1871 in Buenos Aires merits attention and careful scrutiny. Contemporary and subsequent studies have repeatedly focused on the social, spatial and demographic changes that occurred as result of the catastrophe. Less discussed are two items of secular importance: the influence that the epidemic had on the maturation of the public sphere and the disaster's lasting effects on the formation of the state. Though brief, the crisis was a defining moment in the history of the nascent republic and significantly influenced the intellectual debates, policies and state-society relations that shaped Argentina's development during the famed belle époque period that spanned the late nineteenth century up to World War I.

To understand the transformation within the public sphere during the "great epidemic," this chapter will focus primarily on the porteño press and its changing role throughout the disaster. Over a four-month period the epidemic decimated the city's population, crippled the 
local economy and caused a general breakdown in the social structure. Critical of what it claimed to be a slow and inefficient response by those entrusted to protect the health and well-being of the city, the press positioned itself as the defender and voice of the people. When the editorials and printed articles seemed insufficient amidst the growing number of casualties, the newspapers of Buenos Aires united and called for collective action in the creation of a popular commission to combat the disease. The formation of the Comisión Popular was paramount in that it represented a wide cross-section of porteño society. Yet nearly as quickly as it was created, the Comisión fell apart as the loyalties and interests of its individual members proved stronger than its unifying cause. Notwithstanding the limited life of the Comisión Popular and the eventual demise of the epidemic, the press — with a new sense of legitimacy acquired during the outbreak of 1871 continued to utilize the real and imagined notions of disease to shape public opinion and influence government action in response to the perceived enemies that threatened the nation. Purportedly removed from the partisan politics of the period, the hygienists of the late nineteenth century cast themselves as defenders of public health and thereby solidified their right and authority to intervene equally in the nation's public and private spaces.

\section{The Theoretical Nature of the Public Sphere}

The theoretical foundation for the study of the public sphere was established in the writings of the German philosophers/historians Reinhart Koselleck and Jürgen Habermas. ${ }^{1}$ From two divergent approaches, Koselleck and Habermas examined the formation of bourgeois societies in England, France and Germany and their subsequent influence on eighteenth-century politics. Through the medium of print and the establishment of new forms of sociability, the bourgeoisie emerged from the private enclaves of Europe to form a collective public to which the state was accountable. Moreover, Koselleck and Habermas acknowledged that the genesis of a public conscience was both a product of and response to the social, cultural and intellectual

1. Koselleck, Critique and Crisis; Habermas, Structural Formation of the Public Sphere. 
changes brought about by the Enlightenment. ${ }^{2}$ As is evident in their works, the construct of a public was a heuristic device or an analytical lens through which to study various topics relevant to the evolution and growth of modern societies. The versatility of the public sphere as an analytical tool has thus been a powerful reason for its continued use and cross-disciplinary application in scholarship extending beyond eighteenth-century Europe.

Originally published in 1959, Critique and Crisis emanated from the ideas that Koselleck first developed in his dissertation five years earlier at the university in Heidelberg. Amidst the backdrop of post-World War II Europe, Koselleck sought to explain the stronghold of totalitarianism in the twentieth century and the historical basis for the ideologies that philosophically and physically divided his native Germany. Building on Carl Schmitt's theory of the modern state and responding to the writings of Thomas Hobbes, Emmanuel Kant and Pierre Bayle, the young author argued that totalitarian principles evolved within the context of the religious wars of the sixteenth and seventeenth centuries as absolutist states denied their subjects the ability to exercise a political voice. Throughout the eighteenth century the dynamics between the state and its subjects changed as the ideas of the Enlightenment gained momentum through the actions of a critical public. For Koselleck, the tension between the public and the state resulted in a moral dualism: the rational critic in his condemnation of the state was blind to his own political ambitions. ${ }^{3}$ With a propensity towards civil war, the tension culminated in 1789 with the onslaught of the French Revolution; within which the undeniable manifestation of totalitarian ideas was most noticeable in the tenets of the Jacobin movement. ${ }^{4}$

2. For an understanding on how Critique and Crisis and The Structural Transformation have influenced recent historiography see La Vopa, "Conceiving a Public"; Goodman, "Public Sphere and Private Life"; Peter Uwe Hohendahl, The Institution of Criticism (Ithaca, N.Y.: Cornell University Press, 1982).

3. La Vopa, “Conceiving a Public," 82-83.

4. A similar idea is advanced by J. L. Talmon, The Origins of Totalitarian Democracy (New 
In England, critical discourse was able to make relatively seamless transition from the private sphere to the public realm whereas criticism of the state in France and Germany remained within the private circles of the bourgeois and aristocratic elite. Nowhere was this more evident, Koselleck believed, than in the of practice of freemasonry and the proliferation of local lodges in eighteenth-century Europe. ${ }^{5}$ Like the literary salons, academies, and coffee houses of the period, the Masonic lodge established a new kind of social communication or sociability. "Whether one considers the proliferation of local lodges, or the impressive growth in membership, or the social profile of the members, it is clear that by mid-century freemasonry had become the most widespread and inclusive form of the new sociability on which the French and German Enlightenments were grounded."6 Bringing together aristocrats, intellectuals, land owners and merchants freemasonry delineated a space in which it members transcended societal barriers and identities. In the brotherhood of the lodges, Masons were free to distribute printed material, engage in open debate and form a collective opinion.

If the egalitarian nature of freemasonry epitomized the ideals of the Enlightenment, then the antithesis of those ideals was found in its secrecy. "This element," writes Koselleck referring to the cult of secrecy, "so flatly contradicts the spirit of the Enlightenment" that it reveals "the core of the morality-policy dialectic." As historical evidence of this tragic irony, Koselleck pointed to the formation of the Illuminati in 1776 by Adam Weishaupt in the Upper Bavarian

York: Praeger, 1960) See also Helmut Einhalter, ed., Jakobiner in Mitteleuropa (Innsbruck: InnVerl, 1977).

5. Margaret C. Jacob, The Radical Enlightenment: Pantheists, Freemasons, and Republicans (London: Allen and Unwin, 1981); Margaret C. Jacob, Living the Enlightenment: Freemasonry in 18th-Century Europe (New York: Oxford University Press, 1992); James H. Billington, Fire in the Minds of Men: Origins of the Revolutionary Faith (New York: Basic Books, 1980).

6. La Vopa, “Conceiving a Public,” 87.

7. Koselleck, Critique and Crisis, 70. 
region. ${ }^{8}$ Comprised of aristocratic and bourgeois members of society, Weishaupt's order planned a "silent occupation of the State" from within. Suppressed in 1785 and unable to carry out its mission, the Illuminati nevertheless epitomized what Koselleck believed to be the glaring hypocrisy that was evident in such organizations. Within the safety of the Illuminati or behind the closed doors of the lodge, the critic was able to exercise his conscience without accepting political responsibility. Thus the shroud of secrecy that cloaked the Illuminati and the freemasons concealed an underlying zeal for political power and thereby fostered a tone of rebellion and the desire to usurp sovereign authority.

Where Koselleck observed secrecy, hypocrisy and decline, Jürgen Habermas found the opposite. Far from being the bedrock of totalitarian thought, the public sphere was instead a necessary precursor to the growth of the modern state. By turning Koselleck's argument upside down, Habermas' authentic public sphere — characterized by a literate bourgeois, critical and open discourse and accessibility — set the stage for the subsequent development of democratic political institutions in the nineteenth and twentieth centuries. Published in 1962, The Structural Formation of the Public Sphere pointed to the longevity and stability of the literary market and institutions of sociability in Western Europe. Simultaneously, the narrative warned against the ascent of the culture industry and its threat to the modern state. Indeed, the strength of democracy in West Germany and elsewhere rested on the actions of a political public and its collective opinion.

Using England as the model case but also including historical examples from France and Germany, The Structural Formation traced the development of the authentic public sphere in conjunction with and parallel to the emergence of an intimate private sphere. ${ }^{9}$ With the rise of

8. The German and French literature on freemasonry and the Illuminati is well documented in La Vopa, "Conceiving a Public," 90-94.

9. The interaction of the public and private as presented by Habermas is developed in Maza, "Domestic Melodrama" The private sphere is developed in depth in Philippe Ariès and Georges 
capitalism and the market of commodity and information exchange, the once separate domains converged creating a "zone of continuous administrative contact" between the state and its subjects. ${ }^{10}$ Where the two overlapped, the bourgeois, "found certain of their activities the object of public policy, and thus were provoked into using their reason to make critical judgments." ${ }^{11}$ In the words of Habermas, the authentic public sphere was the "private people come together as a public."12 As a public, the bourgeoisie cultivated a new sense self-awareness and further defined themselves vis-à-vis the state by a discourse of criticism used to "challenge and eventually appropriate the public sphere of the monarchy."13

Habermas maintained that the viability of the public sphere was contingent on the circulation of printed material and the presence of institutions of sociability. Novels, newspapers, periodicals and scholarly journals dedicated to science, trade and literature appealed to a literate bourgeoisie and were used as a vehicle for the dissemination of social and political commentaries. ${ }^{14}$ Reading societies, clubs, philanthropic associations and other institutions made Duby, A History of Private Life: Revelations of the Medieval World, A History of Private Life (Cambridge, Mass.: Belknap Press of Harvard University Press, 1988) and in Roger Chartier, $A$ History of Private Life: Passions of the Renaissance.

10. Habermas, Structural Formation of the Public Sphere, 24.

11. Goodman, "Public Sphere and Private Life," 5.

12. Habermas, Structural Formation of the Public Sphere, 27.

13. Goodman, "Public Sphere and Private Life," 7.

14. Jack Richard Censer and Jeremy Popkin, eds., Press and Politics in Pre-Revolutionary France (Berkeley: University of California Press, 1987); Robert Darnton and Daniel Roche, eds., Revolution in Print: The Press in France, 1775-1800 (Berkeley: University of California Press, 1989); Jeremy D. Popkin, Revolutionary News: The Press in France, 1789-1799 (Lexington: University Press of Kentucky, 1990). 
it possible for individuals to gather, discuss and debate the ideas found in print. ${ }^{15}$ In the language of the text:

The process in which the state-governed public sphere was appropriated by the public sphere of private people making use of their reason and was established as a sphere of criticism of public authority, was one of functionality converting the public sphere in the world of the letters already equipped with institutions of the public and with forums for discussion."16

Thus through the rise in printed literature and the new social institutions, the "private society of market exchange formed itself into a network of public communication" and established its own response to the state and its policies. ${ }^{17}$ Throughout the 1960s, Critique and Crisis and The Structural Transformation of the Public Sphere received little attention beyond the range of German scholarship. ${ }^{18}$ The French translation of the two books in the late 1970s led to a "discovery" of the public sphere and its applicability to various topics of research. Of initial

15. Richard van Dülmen, "Die Aufklärungsgesellschaften in Deutschland Als Forschungsproblem," Francia 5 (1977): 251-75; Richard van Dülmen, The Society of the Enlightenment: The Rise of the Middle Class and Enlightenment Culture in Germany (Cambridge: Polity, 1992); Ulrich Im Hof, Das Gesellige Jarhundert: Gesellschaft und Gesellschaften Im Zeitalter der Aufklärung (München: Beck, 1982); Etienne François, Sociabilité et Société Bourgeoise en France, en Allemagne et en Suisse, 1750-1850: Geselligkeit, Vereinswesen und Bürgerliche Gesellschaft in Frankreich, Deutschland und der Schweiz, 17501850 (Paris: Recherche sur les civilisations, 1986).

16. Habermas, Structural Formation of the Public Sphere, 51.

17. La Vopa, "Conceiving a Public," 99.

18. For an overview of the German response to Structural Transformation see Hohendahl, The Institution of Criticism, 242-80. 
interest and coinciding with a new intellectual current in academic circles, scholars on both sides of the Atlantic revisited the history and legacy of the French Revolution. ${ }^{19}$ Equally significant, the use of the public sphere as a heuristic device encouraged historians to return to the central themes of the nineteenth century — nation-building, constitutions, political representation, elections, individual liberties, state-society relations, and public opinion-for new insights and perspectives. ${ }^{20}$ Subsequently, scholarship in the 1980s found further use of the public sphere, including its symbiotic relation to public space, as the interaction between the physical characteristics of city and its human component solidified itself as a relevant subject of research. Furthermore, the shift toward urban social history added significance by emphasizing "social mobility, class conflict, and immigration" and thereby directing attention to the changing "dynamics of neighborhoods and daily life in the city."21

Notwithstanding the theoretical contributions of Koselleck and Habermas, scholarship in the last four decades has not overlooked the relevant shortcomings and perceived inconsistencies of their arguments. For example, Koselleck's narrative identifies a unified Enlightenment in France in Germany and thus neglects the historical differences that distinguished the two states

19. François Furet, Interpreting the French Revolution, Elborg Forster (Cambridge: Cambridge University Press, 1981); Keith Michael Baker, Inventing the French Revolution: Essays on French Political Culture in the Eighteenth Century (Cambridge: Cambridge University Press, 1990); Lynn Hunt, Politics, Culture, and Class in the French Revolution (Berkeley: University of California Press, 1984); Roger Chartier, The Cultural Origins of the French Revolution (Durham, N.C.: Duke University Press, 1991); Benjamin Nathans, "Habermas's 'Public Sphere' in the Era of the French Revolution," French Historical Studies 16, no. 3 (Spring 1990): 620-44.

20. François-Xavier Guerra and Annick Lempériére, eds., Los espacios públicos. Ambigüedades y problemas, Siglos XVII-XIX (Mexico: Fondo Cultural Económico, 1999), 5. 21. Rosenthal, "Spectacle, Fear, and Protest," 34-35. 
and their paths to modernity. ${ }^{22}$ Additionally, Koselleck argues that there was a clear dichotomy between the public sphere of the state and the private space of the new institutions of sociability. In this framework, the membership of the Masonic lodges consisted of those who were unable to "find an adequate place within the Absolutist State's existing institutions." ${ }^{23}$ Subsequent research has questioned this dichotomy and indicates that the new social spaces, including the Masonic lodges, were made up of individuals who were indeed part of the bureaucracy of the state. ${ }^{24}$ Finally, critics point out that Habermas' analysis was based on an elite form of communication that did not consider a under-represented sections of society. As such, "public opinion" was not influenced by the voice of women, the poor, immigrants and other marginalized groups.

Indebted to the intellectual developments noted above, a growing number of talented scholars have highlighted the relevance of the public sphere in the study of Latin American history. For the most part, historians tend to agree that an incipient public sphere for the dissemination of ideas first appeared during the late colonial period. ${ }^{25}$ Within this line of thought, scholars contend that the development of the public sphere was contingent on the proliferation of Enlightenment ideas and was further spurred by the Bourbon reforms of the

22. Peter Hans Reill, The German Enlightenment and the Rise of Historicism (Berkeley:

University of California Press, 1975); Roy Porter and Mikulás Teich, eds., The Enlightenment in National Context (Cambridge: Cambridge University Press, 1981).

23. Koselleck, Critique and Crisis, 66.

24. La Vopa, "Conceiving a Public," 89-91; Robert Darnton, The Business of Enlightenment: A Publishing History of the “Encyclopédie," 1775-1800 (Cambridge, Mass.: Harvard University Press, 1979).

25. François-Xavier Guerra, Modernidad e independencias: Ensayos sobre las revoluciones hispánicas (Madrid: MAPFRE, 1993); Antonio Annino, ed., De los imperios a las naciones: Iberoamérica (Zaragoza: IberCaja, 1994). 
eighteenth century. ${ }^{26}$ In contrast, a limited body of literature on the subject maintains that a public sphere in Latin America did not take shape and mature until the mid-nineteenth century. Proponents of this notion advance the idea that the public sphere was only able to develop in conjunction with the expansion of the press, the proliferation of contending political discourses and the appearance of civil associations that shaped social identities. ${ }^{27}$

As was the case in Europe, the birth and subsequent development of the public sphere in Latin America was made possible by the appearance of institutions that fostered new means of communication or sociability. Informally, pulperias or small city shops that sold dry goods and other products - and that were notorious for gambling, prostitution, and other vices - channeled information into city's neighborhoods. Similarly, the cafés, which attracted a more up scale crowd with some "stature in the community" became gathering spots where local residents and foreign visitors discussed the relevant political events of the period. ${ }^{28}$ Removed from the

26. Uribe-Uran, "The Birth of a Public Sphere," 428 Uribe's bibliography on the public sphere is exceptional and is a worthwile starting point for any scholar interested in the subject. See also Pilar González Bernaldo de Quirós, Civilidad y política en los orgines de la Nación Argentina. Las sociabilidades en Buenos Aires, 1829-1862 (Buenos Aires: FCE, 2000).

27. Sábato, “Citizenship”; Hilda Sábato, Entre el voto y la movilización, Buenos Aires 1862 1880 (Buenos Aires: Sudamericana, 1998); Fuente, "Facundo and Chacho"; Fuente, Children of Facundo; Juan Carlos Garavaglia, "Elecciones y luchas políticas en los pueblos de la campaña de Buenos Aires: San Antonio de Acero (1813-1844)," Boletín del Instituto de Historia Argentina y Americana "Dr. Emilio Ravignani” Tercera seria, no. Num. 27 (1er semestre 2005): 49-74.

28. Szuchman, "Constructing the City," 198-99; Szuchman, Order, Family, and Community, 106-7; Richard W. Slatta, "Pulperías and Contraband Capitalism in NineteenthCentury Buenos Aires," The Americas 38 (January 1982): 349-54 On the economic vitality of the pulperías see Jay Kinsburner, "The Pulperos of Caracas and San Juan During the First Half of the Nineteenth Century," Latin American Research Review 13, no. 1 (1978): 65-85. 
activities of the street, public opinion was also formulated in the tertulias, Masonic lodges, mutual aid societies, and eventually immigrant associations. ${ }^{29}$ In most instances, these organizations were the domain of men but in the case of the tertulias, or salons where literary works were the topic of conversation, British travelers in Buenos Aires noted the presence of women who frequented the discussions with an "almost nightly habit."30

In the more formal settings of sociability, critical discourse was a response to and catalyst for articles published in local newspapers, periodicals and other types of journals. In Mexico, several newspapers were published as early as 1722 and the first daily paper, the Diario de México, appeared in 1805 and remained in print until 1817. Likewise, in Buenos Aires, a handful of newspapers maintained a broad readership during the first decade of the nineteenth century with articles on trade, agriculture, and re-prints of literary pieces published in Spanish newspapers. ${ }^{31}$ Even after independence when military caudillos dominated the regions, the press continued to be a significant means of communication. In both Mexico and Río de la Plata, Antonio López de Santa Anna and Juan Manuel de Rosas used the press to disseminate their political ideologies. In Mexico, El Sol and other conservative papers were instrumental in the

29. González Bernaldo de Quirós, Civilidad y política; Kirsten Schultz, "Royal Authority, Empire and the Critique of Colonialism: Political Discourse in Rio de Janeiro (1808-1821)," Luso-Brazilian Review 37, no. 2 (Winter 2000): 7-31; Enrique de Gandía, La independencia de América y las sociedades secretas (Santa Fe: Ediciones Sudamérica Santa Fe, 1994); Emilio J. Corbière, La masonería: política y sociedades secretas (Buenos Aires: Editorial Sudaméricana, 1998); José Luis Trueba Lara, Masones en México: Historia del poder oculto (Mexico, D.F.: Grijalbo, 2007).

30. S. Samuel Trifilo, "Buenos Aires as Seen by British Travelers, 1810-1860," The Americas 15, no. 1 (July 1958): 48.

31. Uribe-Uran, "The Birth of a Public Sphere," 442-44. 
transition from federalism to centralism and were thus pivotal in the rise of Santa Anna. ${ }^{32}$ Once in power, the santanistas manipulated public opinion through conservative papers such as $E l$ Mosquito Mexicano, Diario del Gobierno, La Lima de Vulcan, El Voto Nacional, and El Nacional and used these as vehicles for printing government propaganda and promoting the image of Santa Anna. ${ }^{33}$ In Río de la Plata, the press likewise provided a means by which the government could communicate policies to the general public and present Rosas as the defender of order and national interest. Until the fall of Rosas in 1852, the official source for news, commentary, and propaganda in Buenos Aires and surrounding provinces was La Gaceta Mercantil. ${ }^{34}$ In both cases, the press also articulated the greatest opposition to the two caudillos.

\section{Disease and Hygiene in Buenos Aires}

From the time of its initial colonization in the sixteenth century, the history of Buenos Aires has been influenced by unexpected epidemics and rampant disease. First established in 1536 by Pedro de Mendoza, a member of the Spanish court and loyal attache of King Carlos I, the colony of Santa María del Buen Ayre was established to deter Portuguese invaders from claiming the territory. Over the next five years, plagues, natural disasters, starvation and frequent Indian attacks decimated the population and by 1541 the last settlers abandoned the fort and fled northward along the Paraná River to join earlier dissenters who had discovered more favorable conditions in Asunción del Paraguay. In 1580, hoping to secure the river trade routes in the region, Juan de Garay, Governor of Asunción, organized and led an expedition to reclaim Mendoza's lost realm. In July of the same year, Garay's company of sixty-six men anchored their ship off the west bank of the estuary of the River Plate and began to build a garrison near

32. Michael P. Costeloe, The Central Republic in Mexico, 1835-1846: Hombres de Bien in the Age of Santa Anna (Cambridge: Cambrdge University Press, 9993), 59.

33. Costeloe, Central Republic in Mexico, 113.

34. John Lynch, Argentine Dictator Juan Manuel de Rosas, 1829-1852 (Oxford: Clarendon Press, 1981), 182. 
what is now the Plaza de Mayo. Trade with Asunción, Santa Fe, Córdoba and other Spanish outposts provided access to necessary provisions and the steady arrival of new settlers proved beneficial against marauding Indians, however, as with Mendoza's first settlement, the regular occurrence of old and new world plagues cast a precarious shadow over the nascent colony. For example, in 1605 a violent outbreak of measles nearly obliterated the city and twenty years later a typhoid epidemic killed 700 of the 1500 settlers. $^{35}$ As can be expected, subsequent episodes of measles and typhoid increased in relation to the demographic growth of the city. Between 1700 and 1799 there were less than a half dozen outbreaks of typhoid. In contrast, almost twenty typhoid epidemics tormented the porteño population the following century. Similarly, there were eight recorded outbreaks of measles in Buenos Aires in the eighteenth century and more than fifteen devastating epidemics of the same disease during the next one hundred years. ${ }^{36}$ In addition to measles and typhoid, other maladies such as dysentery, cholera, smallpox, scarlet fever, diphtheria, tetanus and influenza beleaguered the porteño population-sometimes simultaneously_ and caused sickness and death in the city's neighborhoods. ${ }^{37}$ The prevalence of the numerous diseases often elicited sarcastic observations from those who questioned Mendoza's christening of the site as the city of "Fair Winds." One traveler who visited the city in the mid

35. Nicolás Besio Moreno, "Historia de las epidemias de Buenos Aires: Estudio demográfico y estadístico," in Públicaciones de la Cátedra de la Historia de Medicina, vol. III (Buenos Aires: Universidad de Buenos Aires, 1940), 89.

36. Pedro L. Luque, “Apuntes históricos sobre epidemilogía americana, con especial referencia al Rio de la Plata," Revista de la Universidad Nacional de Córdoba (1941): 128-31Córdoba.

37. Mentionable epidemics of nineteenth-century Buenos Aires include the following: dysentery $(1855,1859,1860,1868)$; measles $(1858)$; smallpox $(1853,1871)$; scarlet fever $(1853)$; cholera (1867-1868); and typhoid 1866,1869). See Besio Moreno, "Historia de las epidemias de Buenos Aires," 137-45. 
nineteenth century simply scorned, "Buenos Ayres! What a misnomer!"38

In most cases, eighteenth and nineteenth century porteños were all too familiar with the potential ramifications once a given disease presented itself in the city. Unknown at the time, however, were the causes of epidemics and the factors that led to the propagation of infectious diseases within a population. As late as 1870 , around the same time that Louis Pasteur and Robert Koch were actively studying germs and microorganisms in the labs of Europe, Eduardo Wilde, a medical student at the Universidad de Buenos Aires and subsequently one of Argentina's foremost authorities on hygiene, would write in the opening pages of his doctoral thesis, "we know so little in medicine about the relationship between the cause and the disease that it might be well that we knew nothing at all." ${ }^{39}$ To compensate for the lack of knowledge, medical practitioners relied on speculation and theorized that contagious illnesses were the result of unseen gases, miasmas, that emanated from living and dead organisms. Describing miasmas, one Argentine doctor referred to them as "impalpable beings that swarmed and spontaneously generated in the air." Moreover, the "irritating gases" could be found on any surface and when disturbed mixed with the "atmospheric dust particles" to "penetrate the bodies of patients" through the air that they breathed. ${ }^{40}$ Dr. Jacob de Tezanos, one of Wilde's contemporaries admitted that "the nature of miasmas are unknown" but asserted, "we know they exist because the effects that they produce are indisputable." 41

38. Trifilo, "Buenos Aires as Seen by British Travelers, 1810-1860," 39.

39. Scenna, Cuando murió Buenos Aires, 1871, 143.

40. See J.C. Llames Massini, La partera de Buenos Aires y la Escuela de Parteras (Buenos Aires: Flaiban and Camilloni, 1915), 133,139; cited in Kristin Ruggiero, Modernity in the Flesh: Medicine, Law, and Society in Turn-of-the-Century Argentina (Stanford: Stanford University Press, 2004), 85.

41. Jacob de Tezanos, "Infección y contagio" (Universidad de Buenos Aires, 1872); cited in Scenna, Cuando murió Buenos Aires, 1871, 142-43. 
The idea of airborne miasmas was simple and explained the numerous ailments that often agitated the porteño population. John Constanse Davie, a British traveler to Argentina, recorded his own experience of falling ill from the miasmas present in the "dense and heavy fogs" of the winter months. Davie "a gentleman of liberal education and considerable property," departed from London in 1797 after "having been disappointed in his hopes of happiness with a beloved female." Stopping first in New York for a brief period, he continued his journey travelling along the coast of South America. In July, near the River Plate, Davie became ill and was left in the care of the priests of the St. Dominic order where he remained for seventeen months. In one entry of his diary, the traveler wrote:

I am at present much and seriously indisposed, having for the last two days felt strong feverish symptoms. The quantity of James' powders which I have been accustomed to take have not had the desired effect; I feel an unusual pain in my limbs, a difficulty of respiration, and an uncommon tenseness over my eyes. ... Though the symptoms I feel are new to me, yet I am willing to think there is no danger in the distemper, my kind host assures me otherwise; it being, he says, an epidemic disease. . . frequently fatal to Europeans.

Uncertain of his fate, he concludes, "There is no precise period for the termination of this disorder; it depends principally on the temperature of the patient: some linger in it for many months, others only a few months; and some only a few days, when it proves fatal. Should the latter be the case, this will be the last letter you ever receive from me, for it is with great difficulty I now write."42 Within time, Davie's symptoms subsided and the British traveler continued his

\section{John Constanse Davie, Letters from Paraguay: Describing the Settlements of Montevideo} an[d] Buenos Ayres; the Presidencies of Rioja Minor, Nombre de Dios, St. Mary and St. John, with the Manners, Customs, Religious Ceremonies of the Inhabitants: Written During a Residence of Seventeen Months in That Country (London: G. Robinson, 1805), 40-41. 
journey, content to leave behind the "dangerous disorder" that nearly took his life.

Fortunately, the troublesome fogs described by Davie were seasonal and relatively sporadic. Of greater concern to porteños was the deplorable condition of the River Plate and its local tributary, the Riachuelo, that meanders through the city's southern neighborhoods. Prior to the extensive public works projects carried out in the late nineteenth century, most families in Buenos Aires relied on the two aforementioned rivers as their primary source for potable water. Aguateros or water vendors made their living by bringing barrels of water into the city and peddling it to those who did not have their own wells or other methods for collecting water. One observer was appalled to see that the aguateros collected the water from the same area of the river where the wash women or lavenderas were busy at work. ${ }^{43}$ To curb the practice, the governor of Buenos Aires issued a decree (bando) in 1770 that prohibited the water vendors from filling their vessels from the "stretch of river that fronts the city." A penalty of one hundred lashes was established for those who violated the mandate. ${ }^{44}$ Unfortunately, few heeded the announcement or enforced its required consequences. "The common people, and those not taking the necessary precautions," lamented Concolorcorvo in his visit to the city in 1771, "drink impure water that is left between the rocks when the river lowers, where clothes from the whole city are washed; there the Negroes draw it in order to avoid the bother of wading into the current of the river." Nearly two hundred years later, the practice continued to bewilder foreign visitors who observed the "Buenos Ayrean naiads of the oceanic washtub" and the "lazily perambulating" water carrier intermingled on the river shores. ${ }^{45}$

43. Woodbine Parish, Buenos Ayres, and Provinces of the Rio de la Plata (London: J. Murray, 1852), 195; Parish, Buenos Ayres.

44. Ricardo González Leandri, "La higiene antes de los médicos higienistas Buenos Aires: 1850-1870,” Desmemoria 5, no. 18 (May/August 1998): 172.

45. Hadfield, Brazil, the River Plate and the Falkland Islands, 278; Parish, Buenos Ayres, 105. 
Equally, if not more, disturbing was the practice of the meat-salting businesses (saladeros) and the slaughtering yards that dumped their waste into the Riachuelo. ${ }^{46}$ According to one article, because of such practices the river did not even have the appearance of water but rather resembled a "torrent of pus escaping from an open wound near the earth's gangrenous breast." ${ }^{47}$ In 1829 hides and other meat products accounted for sixty-five percent of the country's total exports and by the mid-nineteenth century, the saladeros butchered more than 300,000 animals a year. ${ }^{48}$ The concentration of saladeros and slaughterhouses in the southern district of the city was considered an annoyance and elicited frequent complaints from the locals. After a series of grievances in 1830, a commission was established to investigate the concerns. Upon completing their inquiry, the report published by the committee explained that the "rankness was due to the fermentation of blood" that abounded on the premises. Moreover, the report noted that given the lack of employees to clean the site, nearly one hundred pigs were used to eat the "remains of the sacrificed animals" and the leftover bones were "burned at the hour of sunset."49 Several decades later, the saladeros continued to pose a problem with one article in La Revista de Buenos Aires claiming that over a thousand barrels of blood and animal waste were dumped into the Riachuelo on a daily basis. In disgust, the article lamented "we once had a river with good

46. Alfredo J. Montoya, Historia de los saladeros argentinos (Buenos Aires: Editorial Raigal, 1956).

\section{La Nación, February 15, 1871.}

48. David Rock, Argentina, 1516-1987: From Spanish Colinization to Alfonsín (Berkeley: University of California Press, 1985), 95-96; Jonathon C. Brown, "Revival of the Rural Economy and Society in Buenos Aires," in Revolution and Restoration: The Rearrangement of Power in Argentina, 1776-1860, ed. Mark Szuchman and Jonathon C. Brown (Lincoln: University of Nebraska Press, 1994), 242.

49. Rafael Alberto Arrieta, Centuria porteña; Buenos Aires según los viajeros extranjeros del siglo XIX (Buenos Aires: Espasa-Calpe, 1944), 35. 
water. . but the saladeristas needed it and once it was given to them they immediately poisoned it." 50

For the most part, the unsanitary conditions and practices that characterized the city formed part of the daily porteño experience and public hygiene- - both in practice and in the discourse of the period - did not gain relevance until the mid-nineteenth century. The creation of the Consejo de Higiene Pública in 1852 under the auspices of the province of Buenos Aires and the subsequent formation of the municipal Comisión de Higiene in 1857 served to legitimize the role of government in matters of hygiene and public health. Initially, the Consejo assumed jurisdiction over vaccinations, home inspections, and the sanitary police that monitored the city's port. Over the ensuing decades, the influence of the Consejo extended beyond the activities noted above and in doing so the government agency established its control over a broader spectrum of issues relating to hygiene. For example, by 1871 , the Consejo monitored the sale of medicine and food products; inspected the city's slaughterhouses, cemeteries, and hospitals; and carried out initiatives to protect the population against disease and natural disasters. In contrast, the focus of the Comisión de Higiene was directed more towards matters of health in the respective neighborhoods. As such, the Comisión oversaw the efforts of the physicians assigned to parish hygiene commissions including medical home visits and disinfections and oversaw the cleaning of streets and other public spaces. ${ }^{51}$

50. "La Peste" cited in Salessi, Médicos maleantes y maricas, 52. See also Miguel Puiggari, Sobre la inocuidad de los saladeros o sea la refutacion de los cargos hechos a estos establecimientos como instrumentos de insalubridad, y prueba de las preocupaciones que dominan sobre las condiciones sanitarias de las industrias analogas (Buenos Aires: Imprenta La Tribuna, 1871); and V, B., and R., Los saladeros y la fiebre amarilla.

51. Adriana Alvarez, "Resignificando los conceptos de la higiene: El surgimiento de una autoridad sanitaria en Buenos Aires de los años 80," Historia, Ciências, Saúde-Manguinhos 6, no. 2 (July/October 1999): 293-314. 
In the public sphere, the discourse of hygiene prior to the 1850 s was primarily limited to information published in the city's newspapers and often came as a response to an epidemic of some sort that plagued the city's population. However, in 1858 with the publication of the Revista Farmacéutica, the notion of hygiene and the urban environment acquired greater significance among physicians and pharmacists. ${ }^{52}$ Subsequently, the appearance of the Revista MédicoQuirúrgica in 1864 elevated the discourse of public health to a new level with an article in one of the first issues asserting that hygiene was a "primary necessity" and a "principle responsibility of governments." 53 Over the next seven years leading up to the yellow fever epidemic of 1871, the Revista Farmacéutica, the Revista Médico-Quirúrgica, and the popular press monitored the hygienic state of the Buenos Aires and sounded the alarm when "unknown or strange diseases" presented themselves in the city. ${ }^{54}$ Moreover, the discourse in the various periodicals served as a constant reminder to the Consejo de Higiene and the Comisión de Higiene that it was their "obligation" to "monitor the public hygiene" of the population. ${ }^{55}$

The Yellow Fever Epidemic of 1871

The history of yellow fever in the Americas dates to the sixteenth century when slave ships introduced the disease to port cities along the Atlantic seaboard. ${ }^{56}$ Endemic in the tropical and subtropical regions of Africa and South America, the disease is transmitted by the bite of the female mosquito Aedes aegypti and was considered to be one of the most dreaded plagues of the period. ${ }^{57}$ Symptoms associated with yellow fever appear after an incubation period of three to six

52. González Leandri, "La higiene antes de los médicos higienistas," 45.

53. "Higiene," Revista Médico Quirúrgica año I, no. 17 (8 December 1864): 297-98.

54. “Higiene,” Revista Médico Quirúrgica año 3, no. 3 (8 May 1866): 40.

55. "Consejo de Higiene Pública," Revista Médico Quirúrgica año 1, no. 2 (23 April 1864): 21.

56. François Delaporte, The History of Yellow Fever: An Essay on the Birth of Tropical Medicine (Cambridge: MIT Press, 1991).

57. Carlos Finlay, a Cuban doctor and scientist speculated in 1881 that the disease was 
days at which time the victim begins the first of three phases of the disease. Initial symptoms include fever, headaches, chills, loss of appetite, nausea, and moderate to severe pain in the back and joints. These ailments often persist for three to four days and then subside as the disease enters into a period of remission. At times, during this remission it is possible that the victim will recover completely and thereby develop the necessary immunities to protect against future inoculation. Such cases are generally rare and in most instances the victim passes into the third or toxic phase of the disease. Previous symptoms return with greater intensity accompanied by extreme abdominal pain and signs of jaundice as the liver and kidneys begin to shut down. Over the next ten to fourteen days, the victim suffers from gastrointestinal bleeding thus producing the black, blood filled vomit characteristic of the disease. Moreover, the persistent fever causes brain damage eventually leading to bouts of delirium and periodic seizures. Almost simultaneously, the body's various organs cease to function and the patient enters into an intermittent or permanent coma prior to and up until death.

One of the first recorded epidemics of yellow fever in the Americas occurred during the month of September in 1647 on the island of Barbados. The "Barbados Distemper" as it was called, persisted throughout the rest of the year and into the next producing nearly 6,000 deaths. Subsequent epidemics dotted the Caribbean basin with appearances of yellow fever in San Juan, Puerto Rico; Havana, Cuba; and multiple cities along the Mexican coast and Yucatán peninsula. ${ }^{58}$ Over the next forty years, yellow fever extended beyond the Caribbean into North America with outbreaks in New York in 1688, Charleston and Philadelphia two years later, and Boston in 1691. ${ }^{59}$ In 1793, Philadelphia was again assailed by a devastating epidemic, which, in a four month period of time, claimed nearly 4,000 lives and caused a general exodus from the city-

transmitted by mosquitoes. In 1900, Dr. Walter Reed confirmed Finlay’s hypothesis.

58. Cook, Born to Die, 179-80.

59. Cook, Born to Die, 181. 
including President George Washington, his Cabinet, and members of Congress. ${ }^{60}$ New Orleans was repeatedly attacked by yellow fever and experienced catastrophic epidemics in 1853, 1878 and again in 1905. The 1878 occurrence has been the subject of recent scholarship with particular attention to the geographic scope of the epidemic and the destruction that it caused as the disease pushed north into the Mississippi Valley. ${ }^{61}$ In South America, beyond the Caribbean and subtropical regions, yellow fever migrated at a slower pace. Guayaquil felt the brunt of two separate epidemics in the 1740 s and a severe outbreak nearly a hundred years later in $1842 .{ }^{62}$ Yellow fever accompanied General José de San Martín during his campaign in Peru and as a

60. J.H. Powell, Bring Out Your Dead: The Great Plague of Yellow Fever in Philadelphia in 1793 (Philadelphia: University of Pennsylvania Press, 1949).

61. Jo Ann Carrigan, "Yellow Fever in New Orleans, 1853: Abstractions and Realities," The Journal of Southern History 25, no. 3 (August 1959): 339-55; John Duffy, Sword of Pestilence: The New Orleans Yellow Fever Epidemic of 1853 (Baton Rouge: Louisiana State University Press, 1966); John Ellis, Yellow Fever and Public Health in the New South (Lexington: University of Kentucky Press, 1992); Jo Ann Carrigan, The Saffron Scourge: A History of Yellow Fever in Louisiana, 1796-1905 (Lafayette: University of Southwestern Louisiana, 1994); Edward J. Blum, "The Crucible of Disease: Trauma, Memory, and National Reconciliation During the Yellow Fever Epidemic of 1878," The Journal of Southern History 69, no. 4 (November 2003): 791-820; Khaled J. Bloom, The Mississippi Valley's Great Yellow Fever Epidemic of 1878 (Baton Rouge: Louisiana State University Press, 1993); Molly Caldwell Crosby, The American Plague: The Untold Story of Yellow Fever, the Epidemic That Shaped Our History (New York: Berkeley Books, 2006).

62. Cook, Born to Die, 181; Lois F. Parks and Gustave Nuermberger, "The Sanitation of Guayaquil," Hispanic American Historical Review 23 (Febuary 1943): 197-221; Michael E. Connor, "El dominio de la fiebre amarilla en el Ecuador," in La fiebre amarilla y los médicos de Guayaquil (Guayaquil: Archivo Historico de Guayas, 1987). 
result hundreds of soldiers died from the disease in March and April of $1821 .^{63}$ Three decades later, in 1853, the pestilence once again reached epidemic proportions and unmercifully decimated the city of Lima. Asunción was spared from yellow fever until the late nineteenth century when Brazilian troops occupied the city in 1869 during the War of the Triple Alliance and introduced yellow fever into the Paraguayan capital. ${ }^{64}$

In Buenos Aires, three outbreaks of yellow fever preceded the great epidemic of $1871 .^{65}$ The first occurred in 1852 and was relatively brief and caused few deaths; in contrast, outbreaks in 1858 and again in 1870 were not as benign. The first death associated with the epidemic of 1858 was recorded on March 19 in the neighborhood of San Telmo. The victim, a middle-aged woman, contracted the disease from her husband, a dock worker, who, the week before, helped unload the cargo of a ship from Brazil purportedly carrying passengers with yellow fever. Within

63. Ruiz Moreno, La peste histórica, 72.

64. Vera Blinn Reber, "The Demographics of Paraguay: A Reinterpretation of the Great War, 1864-70," Hispanic American Historical Review 68, no. 2 (May 1988): 313.

65. Jacobo Scherrer, "Estudios sobre la fiebre amarilla del año 1871" (Biblioteca de la Facultad de Medicina: Universidad de Buenos Aires, 1872); Miguel Echegaray, "Fiebre amarilla del año 1871" (Biblioteca de la Facultad de Medicina: Universidad de Buenos Aires, 1872); Salvador Doncel, "La fiebre amarilla de 1871 observada en el Lazareto Municipal de San Roque" (Biblioteca de la Facultad de Medicina: Universidad de Buenos Aires, 1872); Penna, "Estudio sobre las epidemias"; José Penna, Consideraciones sobre los casos de fiebre amarilla importados (Buenos Aires: Imprenta de la Universidad de Buenos Aires, 1883); Bucich Escobar, Bajo el horror; Besio Moreno, "Historia de las epidemias de Buenos Aires"; Carlos Fonso Gandolfo, "La epidemia de fiebre amarilla de 1871," in Públicaciones de la Cátedra de Historia de la Medicina, vol. III (Buenos Aires: Universidad de Buenos Aires, 1940); Ruiz Moreno, La peste histórica; Scenna, Cuando murió Buenos Aires, 1871; William J. Dwyer, "Buenos Aires Under Terror: A Case Study of the Yellow Fever Epidemic of 1871” (Medical Library: Yale University, 1992) 
a matter of days of the first casualty, two other cases of yellow fever were diagnosed in the same household located at 242 Balcarce. Between March 25 and April 4, seven more victims fell ill as the disease spread to additional family members residing in the home and to neighbors who also lived on Balcarce. To stay the disease, municipal officials imposed stiff quarantines but were unable to keep the epidemic from migrating from San Telmo into other areas of the city. The outbreak persisted through April and into May eventually subsiding with the change in seasons and the cooler weather. Notwithstanding the brevity of the outbreak, the six to eight week ordeal ended with an estimated 300 fatalities. ${ }^{66}$

Twelve years later, yellow fever once again reached Argentine shores after the French ship, Poitou, stopped in Brazil prior to its final destination of Buenos Aires. Having set sail on February 7 from Rio de Janeiro- where an epidemic of yellow fever that would eventually take over 3,000 lives was gaining momentum - the ship reached Buenos Aires the following week and officially declared no sick travelers or crew members. Nonetheless, on February 22, a passenger who had arrived on the Poitou died of yellow fever while rooming at the Roma hotel on Cangallo street. Despite efforts of the Consejo de Higiene Pública to disinfect the hotel and enforce a fifteen day quarantine for individuals that had contact with the victim, residents of a nearby conventillo promptly showed symptoms of the plague thus confirming that the disease had already initiated its treacherous march through the city. Though ultimately less destructive than the previous outbreak, the epidemic of 1870 accounted for 200 casualties; a mere fraction of the amount that would succumb to the disease the following year. ${ }^{67}$

Unlike the yellow fever epidemics of 1858 and 1870, historians are less certain as to when and how the disease infiltrated Buenos Aires so as to initiate the great epidemic of 1871 . Generally agreed upon is the belief that the pestilence originated in Asunción, Paraguay and from there eventually spread to Corrientes, a city near the Argentina-Paraguay border and located

66. Scenna, Cuando murió Buenos Aires, 1871, 162-64; Ruiz Moreno, La peste histórica, 71. 67. Scenna, Cuando murió Buenos Aires, 1871, 174-75. 
about 1,000 kilometers north of Buenos Aires, subsequently migrating south via an infected traveler who made the difficult journey by land or perhaps sailed along the Paraná River and successfully evaded the vigilant watch of the medical team stationed at the Buenos Aires port. News of a yellow fever epidemic in Asunción reached Corrientes early in December 1870 at which time the Captinancy of the Port and the Medical Tribunal recommended that any ship proceeding from Paraguay be redirected to a small island situated a distance of a half league from the city. Under strict isolation, doctors would monitor passengers for any signs of the disease and, at their discretion, permit the traveler to continue on into Corrientes or be consigned to a stipulated quarantine. ${ }^{68}$ The recommendation proved to be too late as the first victim of the disease was diagnosed on December 14 and died two days later. At a meeting on December 17, the Municipal Council of Corrientes agreed to act on several initiatives intended to protect the health of the public. The ordinance included regulations on the sale of water and fruit and a prohibition on the construction of latrines. Furthermore, any victim of yellow fever was to be buried in the new San José cemetery and immediately covered with lime. ${ }^{69}$

Anticipating the magnitude of the menacing epidemic, the national government sent Dr. Pedro Mallo, one of the two members of the Medical Council of the Captaincy of the port of Buenos Aires, to Corrientes as a special envoy to assist local doctors in their efforts against the disease. Notwithstanding the young doctor's talents and his past experience with yellow fever, the overall deficiency in resources made it nearly impossible for Mallo to carry out his assignment: medicine was scarce, the number of trained medical professionals were few in number and the treasury of the province of Corrientes was nearly depleted as a result of the six-year long War of the Triple Alliance that pitted Argentina, Brazil, and Uruguay against the Paraguayan president, Francisco Solano López. Dr. Mallo's time in Corrientes ended abruptly when the Medical Tribunal disagreed with the porteño physician on how to attend to the quarantined patients and

68. Ruiz Moreno, La peste histórica, 361.

69. Scenna, Cuando murió Buenos Aires, 1871, 184-86. 
refused to accept his continued collaboration. On December 31, Mallo embarked for Buenos Aires leaving behind a situation that quickly deteriorated. Over the following four months, nearly 900 men, women and children fell victim to the disease and over sixty percent of the population fled the city. ${ }^{70}$ Upon his return to Buenos Aires, the ever vigilant Mallo drafted a letter on January 13, 1871 to Colonel Francisco Borjes, Commander and Chief of the Plaza. Signed by Mallo and two of his colleagues, doctors Francisco Soler and Anjel M. Donado, the letter outlined eighteen measures necessary to protect Buenos Aires against the "importation, transmission, and propagation of the epidemic that from the North advances towards this port, spreading havoc and invading towns along the river."71

Unbeknownst to Mallo at the time of the letter was the reality that the first cases of yellow fever that would eventually initiate the catastrophic epidemic of 1871 were certain to have already occurred. On December 23, 1870 the Revista Médico Quirúrgica, reporting on the overall health of Buenos Aires during the previous month, noted "a great increase in sicknesses" with a "tendency to acquire a pernicious and infectious character." The Revista did not mention yellow fever in its assessment but instead concluded that "bilious fevers fill the picture of the dominant sicknesses of this fortnight". ${ }^{72}$ The vague reference to "bilious fevers" was more allusive when on January 11, 1871 a Dr. Santiago Larrosa reported to the Consejo de Higiene Pública that a patient interned at the Men's General Hospital had died from "jaundiced typhus.” Two weeks later, in a letter to the health commissioner of the neighborhood of San Telmo, Dr. Larrosa described:

Eleven patients of which two have ended up dying and one is found to be very gravely ill, likely to pass away today ... With respect to the disease's class that has attacked these

70. Ruiz Moreno, La peste histórica, 364-80.

71. Ruiz Moreno, La peste histórica, 162-64.

72. Penna, "Estudio sobre las epidemias," 25. 
individuals, I think that it is an epidemic fever that would be able to be called malignant icteric fever. In its essence, I believe it identical to yellow fever . . . that reigned in this same city in $1858 .^{73}$

Dr. Luís Tamini, who had personally treated the patients mentioned by Dr. Larrosa, shared his concern and on January 27 the two doctors, accompanied by Dr. Leopoldo Montes de Oca, notified the Comisión Municipal, in closed session, that yellow fever was lurking in Buenos Aires.

Recognizing the potential threat, the Comisión Municipal ordered that the contaminated house at 392 Bolívar be vacated and disinfected. Additionally, the Comisión required the closure of the streets Perú, San Juan and Cochabamba that formed the perimeter of the epicenter and mandated that they be kept watered so as to minimize the movement of dust and other particles that might carry the disease. Finally, the Comisión Municipal agreed to notify the Consejo de Higiene and defer to its lead but decided against a public announcement fearing that such would likely induce panic among the population. Over the next three days, the Comisión waited for a response from the Consejo and haphazardly monitored the situation as new cases of yellow fever manifested themselves in San Telmo. Late in the evening of January 30, the secretary of the Consejo de Higiene arrived at the municipal offices noticeably concerned and indicated that the letter from the Comisión was deposited in a mailbox that had not been opened until that very afternoon. ${ }^{74}$

Unlike the Comisión Municipal, the porteño press refused to be silent about the presence of yellow fever and immediately pushed the issue into the public realm. Initially, the debate centered on the extent of the disease and whether or not the public should be alarmed. La Prensa led the charge with an article on February 1 regarding the three casualties in San Telmo and

73. Dwyer, "Buenos Aires Under Terror,” 42.

74. Bucich Escobar, Bajo el horror, 17. 
claimed that for unknown reasons Dr. Tamini listed typhoid as the cause of death yet solicited preventative measures because of his certainty that the deaths on Bolivar street were in fact a result of yellow fever. ${ }^{75}$ Two days later La Prensa ran a subsequent article titled, "The Population is Alarmed and with Reason." Accusatory in its tone, the piece ridiculed the governing bodies for being more interested in trams and telegraphs than in the public health of the city. In response, the editor of La República, Manuel Bilbao, published a piece on February 9 with the title, "Is Yellow Fever Present Among Us?" Bilbao observed:

For those of us that have traveled to the West Indies where [yellow fever] is permanent; those of us that have resided in Lima in 1853, at which time the fever leveled the city, taking captive 300 individuals in one day out of a population of 100,000; for those of us that were in Guayaquil when an epidemic claimed 8,000 of the total 20,000 that comprised the population, the fever that is said to have appeared in Buenos Aires, is not yellow fever. . . the symptoms that exist among the sick do not correspond to those of the yellow fever that we have known. ${ }^{76}$

Similarly in Montevideo, Dr. Miguel Garbiso, who was instrumental in the relief effort during the 1857 yellow fever epidemic in the Uruguayan capital, shared Bilbao's thoughts and noted that it was unlikely that the deaths in Paraguay and in Buenos Aires were linked to yellow fever. $\mathrm{He}$ believed instead that the affliction was perhaps, "a fever that was putrid, or typhoidal, or bilious, or pernicious, or intermittent, or any process of that order; but not the contagious yellow fever."77

In contrast, Dr. Juan Angel Golfarini, a medical practitioner with over 32 years of experience, asserted that yellow fever was to blame for the recent deaths. However, in a letter to Dr.Tomás Peña, chief of the parish health commission of San Telmo, dated February 18 and

75. La Prensa, February 1, 1871.

76. La República, February 9, 1871.

77. Penna, "Estudio sobre las epidemias," 28-29. 
subsequently published in El Siglo, Golfarini declared, "there exists a great disparity between the truth and the facts, the uproar, the alarm, and the official noise." Golfarini believed "outside of its homeland [yellow fever] walks without venom" and that once the temperatures dropped the disease would return to its "country of origin." Golfarini further contended that it was "ridiculous" to even use the word epidemic being that the death rate in the month of January was no different than in previous years and was moreover comparable to the average mortality of around twenty to twenty-five deaths per day. His letter concluded with a slight reproach noting that the "present pestilence is quite mild . . certainly not worth such an uproar."78

The opinions expressed by Bilbao, Garbiso and Golfarini outraged members of the medical community concerned with the ever increasing number of patients showing symptoms of yellow fever. Of particular concern to the diligent physicians was the belief that the skepticism and ignorance printed in the press would create a sense of complacency that would in turn jeopardize efforts to combat the disease. Responding to the articles, a young doctor by the name of Eduardo Wilde, who having completed his medical studies in March of the prior year and subsequently accepted an appointment to assist Dr. Mallo as part of the Medical Council at the port, questioned the credentials of the cynics and the information they presented. Specifically addressing the claims of Dr. Garbiso, Wilde wrote:

It does not surprise us so much that the editor of La República might put into doubt the existence of the plague for reasons we have said, but it indeed has surprised us to the extreme to receive from Dr. Garbiso, inhabitant of Montevideo and physician of that community, a certificate of ignorance intended for all of the physicians of Buenos Aires. Dr. Garbiso, from a distance, has allowed to be published as his own opinion that what we have been experiencing here is not yellow fever, but some other fever.

78. Ruiz Moreno, La Peste Histórica, 134-35. Golfarino's letter to Peña was published in El Siglo on March 1, 1871. 
Wilde sarcastically jeered that even though Dr. Garbiso had not traveled to Buenos Aires or attended to any patients, it made complete sense that a doctor living in another country would know more about the disease than the doctors of Buenos Aires. "However," Wilde continued, "it seems that the ideas of our colleague on the other shore have been modified a bit and he is starting to see a slight yellow tint in the plague of San Telmo and therefore has started to impose a twelve day quarantine on the ships proceeding from our port." Having diminished the doctor's credibility, Wilde went on to attack Garbiso's diagnostic ability claiming:

Thus if [the epidemic] has not grown in size, it has at least grown in names. Now, those who do not wish to recognize [the disease] for what it is refer to it as malignant bilious fever, bilious remittent fever, bilious intermittent fever, bilious gastroenteritis and lastly, bilious acclimatizing fever. . Everyone can now chose the name that they most favor; as for me I will stick with the name bilious acclimatizing fever for being the most humorous, and because this acclimatizing fever has the notable singularity of attacking, with such violence, those most acclimated, as is the case of Mr. García, a gentleman of eighty years who has never lived anywhere else and yet it seems that he has been unable to acclimate himself to his homeland in the time that he has lived here. ${ }^{79}$

Within a matter of weeks, the debate of whether or not the city was facing an epidemic disappeared from the pages of the newspapers. Exactly one month after his initial editorial in $L a$ República, Bilbao recanted his position and published an article introduced by a one-word headline printed in large, bold type that simply read: "TERROR." 80

In part, the terror of the unfolding drama stemmed from the rapid spread of the disease in a relatively short period of time. Hoping that the pestilence would remain isolated to Bolivar street, authorities were disappointed when the plague ventured to Perú, haphazardly attacked the

79. La República, February 22, 1871.

80. La República, March 9, 1871. 
residents on the nearby street of San Juan, and subsequently targeted those living on Brasil, Piedras, Chacabuco and Cochabamba, in the said order. ${ }^{81}$ From San Telmo, the disease sauntered into the neighborhood of Socorro and occupied a conventillo on Paraguay between Artes (Carlos Pelligrini) and Cerrito. Designed to hold fifty tenants, the dwelling housed 320 including the owner of the property and his family. In addition to the overcrowded conditions of the building, for some unknown reason, the landlord prohibited the removal of the trash to the street. Instead, he required that the refuse be deposited behind the building thus generating a heap of garbage ideal for the proliferation of flies and mosquitoes. Ironically, the first to fall sick to yellow fever was the owner of the conventillo followed by his wife and children. All succumbed to the black vomit and died within days of one another. Having discovered the situation, municipal officials ordered that the tenement be vacated and disinfected thereby forcing the residents to find accommodations elsewhere in the city. ${ }^{82}$ Not surprisingly, by the end of February, the disease was festering in eight porteño neighborhoods with added cases being reported in outlying areas of the city as well. ${ }^{83}$

In addition to the hasty migration of the pestilence, the indiscriminate nature of the disease likewise bewildered the population. During the outbreaks of yellow fever in 1858 and again in 1870 , porteños observed that the disease was primarily confined to the impoverished districts of the city. Based on this perception, some commentators falsely assumed that the epidemic of 1871 would be no different. One article published during the initial weeks of the scourge declared:

81. In his study of the epidemic, José Penna documented the trajectory of the disease as it migrated from one address to the next. See the footnote in Scenna, Cuando murió Buenos Aires, $1871,203$.

82. Scenna, Cuando murió Buenos Aires, 1871, 204.

83. Dwyer, "Buenos Aires Under Terror," 59; Scenna, Cuando murió Buenos Aires, 1871, 212. 
Nearly all of the victims come from families in which the principles of cleanliness and hygiene are not esteemed as virtues; these are people who live in cramped and filthy hovels in the most absolute state of neglect. On the contrary, [yellow fever] respects and will not attack members of society who live differently. ${ }^{84}$

Curiously, the article ignored the existing body of medical knowledge available at the time. In his doctoral thesis published a year earlier, Wilde made reference to the sporadic reputation of the disease and its tendency to disregard age and social classes in its choice of prisoners. On the subject, the doctor warned:

Concerning yellow fever, for example, it is observed that to be ill with other ailments is not reason enough to contract the disease, neither is it a shield of protection to those who find themselves predisposed to the best of health. [Yellow fever] attacks and induces death upon the robust and healthy worker ... who, in the course of his activities is careful to not violate even the least significant of the laws of hygiene. ${ }^{85}$

Perhaps even more odd, the remarks in La Tribuna seemed oblivious to the reality of what was actually happening in Buenos Aires. The Revista Médico Quirúrgica registered six deaths attributed to yellow fever in January and another 318 confirmed casualties the following month. ${ }^{86}$ Among the dead were priests, government officials, doctors, educators and others who, like the

84. La Tribuna, March 3, 1871.

85. Eduardo Wilde, El hipo (Buenos Aires: La Cultura Argentina, 1924).

86. The various historical accounts available on the epidemic are inconsistent as to the number of yellow fever related deaths per month. For purposes of this analysis, I will refer to Scenna's tabulation as presented on pages 492-494 of his study. Scenna cites the following as the source of his numbers: Revista Médico Quirúrgica año VIII, no. 5 (8 June 1871)Buenos Aires. 
poor, were unable to avoid the wrath of the disease. ${ }^{87}$

As the month of February came to an end, Mardoqueo Navarro, an eyewitness to the unfolding tragedy, related in his daily account of the epidemic, "The craziness of Carnival is now past, it is calm; then the panic occurs. . The mortality rate speaks for itself and chaos ensues." 88 Within the first week of March, the panic and chaos alluded to by Navarro intensified as the number of deaths escalated. At first, the increase was subtle with only a dozen or so more casualties per day. Then, without warning, on March 6 the number of deaths in one day surpassed one hundred and continued to climb for the next twelve consecutive days eventually claiming 204 victims on March 18. The figures declined for a brief period and then surged again eventually accounting for 337 fatalities on March 28. Seven days later the deaths reached 400 and on April 10 the mortality rate peaked at 503 causalities. Thereafter, the epidemic began to subside and by April 19 the number of deaths per day dropped below 200 and after May 1 the registries recorded less than one hundred deaths per day. Even with the demise of the outbreak, yellow fever claimed an average of twenty-seven deaths per day throughout the month of May. A summary of the three most devastating months is presented below in the corresponding table:

87. Bucich Escobar, Bajo el horror, 24,27,34-35; Scenna, Cuando murió Buenos Aires, $1871,212-13$.

88. Navarro's diary of the epidemic of 1871 is one of the most referred to sources on the subject. Born in Catamarca, Navarro resided in Buenos Aires most of his life with the exception of a brief period of exile in Chile. In his later years, Navarro was appointed Director of Lands by President Julio Roca. During the outbreak of 1871, the chronicler documented the events of each day as yellow fever consumed the city. Written in short, choppy fragments the diary was first published in La República following the epidemic. Navarro's "Diary" was republished in its entirety in 1894 as part of annual memoir of the National Department of Hygiene. See Mardoqueo Navarro, “La Fiebre Amarilla de 1870-1871," Anales del Departamento Nacional de Higiene (1894): 447-55. 
Table 2.1

Daily number of deaths: March, April May, 1871

In total, the Revista Médico Quirúrgica officially recorded 4,992 deaths in March; 7,564 in April; and 845 fatalities in May. ${ }^{89}$

With the disease raging in every neighborhood, the unprepared porteños grappled with how to best deal with the dead. In an effort to limit the spread of the disease, the government of the province of Buenos Aires prohibited the traditional wake or vigil over the body and local priests refused to hold religious services prior to the internment of a deceased parishioner so as to limit large gatherings that might propagate the disease. Instead, the deceased were to be placed in coffins and left outside where they were collected by a passing funeral wagon and transported to the cemetery. On the subject, Julio A. Muzzio, in his Diccionario Histórico Biográfico de la República Argentina noted the following:

At the height of the epidemic, the city was a dismal and terrifying sight, and in the neighborhoods where the epidemic was most severe, entire families were blown down by the exterminating venom of the disease. Coffins were taken from the homes and stacked three by three to await the wagons that would carry them to the cemetery. By around four in the afternoon, citizens no longer transited the streets and family dwellings and businesses closed their doors thus giving the appearance of a truly infected city; the only sounds heard thereafter were the rolling wheels of the funeral carts and the despicable and sullen voices of their drivers. ${ }^{90}$

When the number of cadavers exceeded the scant supply of coffins, those attending to the dead wrapped the bodies in blankets or simply left them uncovered and collected the bodies into large

89. Scenna, Cuando murió Buenos Aires, 1871, 492-94.

90. Ruiz Moreno, La peste histórica, 330. 
piles to await the passing funeral carriages. Eventually, to expedite the process, the Comision Municipal employed all available garbage carts and their drivers to assist in the gruesome task of removing the deceased from the streets and sidewalks of the city. ${ }^{91}$

The unexpected number of causalities also raised concerns as to the capacity of the already overcrowded cemeteries and the lack of space to bury the victims of the epidemic. At the time, only two secular graveyards existed in Buenos Aires: the Cementerio del Norte or Recoleta and the Cementerio del Sud. Recoleta, the oldest of the two, opened in 1822 following a decree that prohibited the entombment or burial of the deceased in the city's religious sanctuaries. ${ }^{92}$ For more than four decades, Recoleta was the only public cemetery under the direction of the municipality and as such received the city's dead regardless of their material wealth in life — only after the yellow fever epidemic of 1871 did the cemetery acquire a reputation for being the esteemed final resting spot for the illustrious porteño elite. Though removed from the city's most populated neighborhoods, the location of the cemetery still concerned some of the city's residents leading one nineteenth-century observer to claim that in Recoleta, the "living and the dead cohabit in state of awful promiscuity." ${ }^{93}$ Fifty years later, the historian Ismael Bucich Escobar

91. Scenna, Cuando murió Buenos Aires, 1871, 328 In the haste of retrieving the deceased, it appears that the funeral wagons also carried away the living. Such was the case of José Mamerto, a medical assistant who was attending to the ill. After several days of relentless work and perhaps in an effort to escape the nightmare of each passing day, the exhausted Mamerto became inebriated and passed out on his way home. Mamerto's body was placed in a wagon full of jaundiced carcasses and subsequently transported to the cemetery. The medical aide eventually awoke just as he was thrown into common grave by the cemetery workers. See La Prensa; April $15,1871$.

92. Scenna, Cuando murió Buenos Aires, 1871, 152.

93. "La peste," La revista de Buenos Aires-Historia Americana Literatrura y Derecho 95 (1871): 421. 
echoed the concern and further added, "Recoleta was always too cramped; in its interior, chaos prevailed. Graves were dug in a disorderly fashion, in all areas of the cemetery, without any attention given to some form of lineal construction thereby creating a gloomy labyrinth of bricks." 94

By the mid 1860 s, city officials recognized the need to establish another cemetery and purchased several adjoining parcels of land in the southern district of the municipality. Porteños who lived in the neighborhood as well as those who owned country villas (quintas) near the designated site vehemently challenged the proposed action. One of the residents, Miguel Navarro Viola, an attorney and one of the editors of La Revista de Buenos Aires, led the opposition against what he believed was the decision of "inept municipal authorities." Well versed in matters of hygiene and medicine, Navarro Viola asserted that the size of the parcel was insufficient to meet the demands of a growing population. Furthermore, he argued that the planned cemetery was too close to the city and would soon be surrounded by houses thus violating "all laws of science" and principles of good health. ${ }^{95}$

Unconvinced by Navarro Viola's petition and against the recommendation of the Consejo de Higiene, the Comisión Municipal opened the Cementerio del Sud in December 1866 on the assumption that the land would serve the population of Buenos Aires for at least fifty years; an estimate based on the average annual morbidity rates of the period. ${ }^{96}$ Less than a year after the inauguration of the cemetery, the catastrophic cholera epidemic of 1867-1868 marauded the city leaving behind 8,000 fatalities. High mortality figures during an outbreak of typhoid fever in 1869 and once again in 1870 with the aforementioned yellow fever epidemic likewise filled the cemetery at an unanticipated rate. Recognizing the severity of their mistake, municipal authorities

94. Ismael Bucich Escobar, Visiones de la Gran Aldea. Buenos Aires hace sesenta años (Buenos Aires, 1932), 175.

95. Ruiz Moreno, La peste histórica, 349-50.

96. Scenna, Cuando murió Buenos Aires, 1871, 153. 
announced the closure of the Cementerio del Sud only to be ambushed a few months later by the return of yellow fever in 1871. By March 9, after four consecutive days registering more than one hundred deaths per day, the director of the cemetery, Carlos Munilla, suspended the practice of individual internments and instead ordered that a mass grave be excavated for the dozens of bodies that needed to be buried. After hurried negotiations with the federal government, Emilio Castro, governor of the province of Buenos Aires, issued a decree on March 11 authorizing that land in an area outside of Buenos Aires in the district of Belgrano be used for the Cementerio General de la Ciudad de Buenos Aires or the cemetery of Chacaritas. The decree likewise allocated $\$ 2,220,000$ pesos for the construction of a rail spur from the city to the intended burial grounds with work to commence immediately. ${ }^{97}$ The railroad was completed on April 14 and on the same day the first train transported 305 cadavers to the new graveyard. ${ }^{98}$

Surrounded by the constant and increasingly horrifying scenes of sickness and death, thousands of porteños left the city to escape the threatening pestilence. The exodus was both spontaneous and abrupt with one estimate suggesting that by the first week of March more than 53,000 of the 190,000 inhabitants had already abandoned the city. ${ }^{99}$ The dislocation of the population continued throughout the epidemic as the city's residents either fled to nearby cities or, as was the case with many of the recently arrived immigrants, returned to their country of

\section{Ruiz Moreno, La peste histórica, 122.}

98. Bucich Escobar, Bajo el horror, 49-50. With the construction of Chacaritas, the Cementerio del Sur was closed after having received Buenos Aires' dead for only four years. The space was eventually planted with a grove of eucalyptus trees and converted into a public paseo now known as Parque Ameghino. The transformation of the space occurred in part because of the continued efforts of Miguel Navarro Viola who had opposed the cemetery from its inception. See Ruiz Moreno, La peste histórica, 111; Bucich Escobar, Bajo el horror, 352-56.

99. Scenna, Cuando murió Buenos Aires, 1871, 173, 230. 
origin. ${ }^{100}$ On April 4, the Consejo de Higiene debated on whether or not the city should be evacuated but a final decision was never agreed upon. Nonetheless, to assist those who chose to leave on their own, the government of the province of Buenos Aires agreed to pay the required fare on the Ferrocarril del Oeste and for the truly indigent provided temporary housing in the cities of San Martín (Ramos Mejía), Moreno, Morón, and other rural stops located along the rail corridor. ${ }^{101}$ At the height of the epidemic, Buenos Aires appeared to be an uninhabited wasteland. In his diary on the epidemic, Mardoqueo Navarro's entry on for April 9 reads, "the people flee" and two days later he added, "terror reigns" to portray the ensuing chaos. Though impossible to determine precisely how many people actually left, it is generally accepted that about $65-70 \%$ of the population abandoned the city. ${ }^{102}$

The Porteño Press and the Comisión de la Salud Pública

The dismal situation in Buenos Aires energized the local press and in many ways demonstrated the vitality of the porteño public sphere. At the outset of the epidemic, Buenos Aires boasted no less than fifteen regularly published newspapers, of which nearly half were directed to immigrant communities in the city and were printed in non-Spanish languages. Furthermore, the epidemic provided the opportunity for the appearance of additional publications. Such was the case with the Boletin de la Epidemia edited by Juan Pablo Albarracín and Juan Güemes that first appeared on March 28. On the front page of the first edition, the editors

100. On March 2, the Ferrocarril del Oeste sold over 4,000 tickets for passage to its various destinations in the province of Buenos Aires. See Bucich Escobar, Bajo el Horror, 36. Immigrants with the financial resources to leave Argentina did so instead of migrating within the country. During a fifteen day period, La Compañia Genovesa sold 5,200 return passages to Europe. See Allison William Bunkley, Vida de Sarmiento (Buenos Aires: Editorial Universitaria de Buenos Aires, 1966), 115 cited in Scenna, Cuando murió Buenos Aires, 1871, 319.

101. Scenna, Cuando murió Buenos Aires, 1871, 351-52.

102. Bucich Escobar, Bajo el horror, 36; Scenna, Cuando murió Buenos Aires, 1871, 341-42. 
promised, "When a newspaper is born, it desires a long life ... We, on the contrary, desire a quick demise, and say so with sincerity, because with this being a newspaper born of circumstance, an early demise will signal the end of the epidemic."103 Indeed, Albarracín and Güemes were consistent to their word but other publications were not able to have a continued presence in the public realm as the epidemic unselectively claimed its victims. The first paper to stop publication was La Discusión on March 23. Two weeks later, a shortage of employees caused Le Republicain and The Standard to close their doors and on April 4 the Freie Presse, El Fénix, Eco d'Italia, and Nazione Italiana became unavailable at the newsstands. Once yellow fever disappeared, many of these papers resumed printing while others ceased to exist altogether. ${ }^{104}$ Only four newspapers, La Nación, La Prensa, La República and La Tribuna remained in continuous circulation during the entire outbreak and by so doing were able to firmly establish themselves within the debates and arguments specific to the epidemic and more generally to the discussions that would eventually shape the development of the nation.

Unable to identify the source of the outbreak or account for its intensity and duration, editors of the various newspapers pointed the finger of blame towards anything and anyone that was potentially culpable. One article identified a list of hygienic atrocities including the unsanitary manner in which victims of the epidemic were handled, the common spectacle of porteños urinating in the streets, and the presence of dead horses and mules left to rot along the public thoroughfares. ${ }^{105}$ Disgusted, La Prensa reminded its readers that, "Just as cleanliness of the human body is a necessary element for the conservation of good health, within a large population, cleanliness and the conservation of all of the conditions of hygiene are an essential element for the health and regular development of a city's numerous inhabitants." "106 Evident was

103. Scenna, Cuando murió Buenos Aires, 1871, 305-6.

104. Scenna, Cuando murió Buenos Aires, 1871, 305-50.

105. La Prensa, May 4, 1871

106. La Prensa, February 6, 1871. 
the conclusion that "the lack of hygiene in life, in habits, in living quarters, and in food favorably promotes the spread of disease," and that "good hygiene is undoubtedly the most effective manner of guarding oneself from a repeat outbreak."107

The conditions noted by the press were not new phenomena in Buenos Aires but instead stemmed from decades of unsanitary practices and neglect. In fact, La Prensa blamed the various administrations and claimed that in regards to issues of public health "the [state and federal] governments have done little, the municipality almost nothing."108 As an example of such neglect, La Prensa reminded the community of Buenos Aires that months before the first cases of yellow fever appeared in the city, the legislature initiated discussions on the development of a water drainage system, sewers, and paved streets. The law itself was drafted in September 1870 but without a timeline for implementation, plans for the projects were left on the drawing board. By the time of the disaster, no action had been taken whatsoever. ${ }^{109}$ La Prensa criticized the government for its procrastination and urged administrators to immediately allocate funds not only for the projects mentioned above but for other initiatives that would improve the hygiene of the city. ${ }^{110}$

More than anything the press understood the importance of establishing permanent measures that would keep an epidemic of such magnitude from recurring. Of particular concern to La Prensa were the slaughterhouses, the unhealthy condition of the Riachuelo, and the small and often overcrowded rooms for rent (conventillos/barracones) scattered throughout Buenos Aires. The slaughterhouses located in the southern neighborhood of Barracas and the Riachuelo had long carried the reputation of being unsanitary and were frequently cited as the sources of the many deadly plagues that battered the city. With the first deaths of yellow fever, the Consejo de

107. La Prensa, May 3, 1871.

108. La Prensa, April 25, 1871.

109. La Prensa, May 3, 1871.

110. La Prensa, May 15, 1871. 
Higiene strongly urged the owners of slaughterhouses to temporarily cease their activities yet despite this recommendation business continued thus proving to the press that public officials were more concerned about financial profits than they were about the health of their citizens. ${ }^{111}$ One columnist in La Tribuna reminded porteños that the slaughterhouses and the Riachuelo were intrinsically connected and that the unhealthy conditions of these two were the focus of public discourse year after year. Somewhat exasperated, the author of the article wrote:

Six years ago we embarked on a campaign against the permanent epicenter [of disease] that is known in Buenos Aires with the name of Riachuelo. Three years later, when cholera [appeared], we returned to initiate our campaign against this receptacle of putrefaction, that flows in Barracas like a constant threat against public health. The campaign provoked great protests from vested interests when we requested the removal of the slaughterhouses, whose refuse infests and poisons the waters of the Riachuelo. Commissions were named, decrees were issued, but at the end, nothing was done leaving the situation as it used to be. . Therein lies the true reservoir of infection, the primordial source that poisons of the atmosphere. ${ }^{112}$

Similarly, a study by a certain D.F. Schwarz argued that epidemics always began in the neighborhood of San Telmo around the streets that ran in an East to West direction and received the winds from the Riachuelo first. ${ }^{113}$

111. La Prensa, March 9, 1871.

112. La Tribuna, February 26, 1871.

113. The findings of this study were presented to the government by Schwarz along with a proposal for cleaning the river. Schwarz believed that by building a dam across the Riachuelo it would be possible to create a reservoir of water, that when needed could be released with enough pressure to clean the "fango" from the river. See the article in La Prensa, March 9,1871. 
Perhaps the topic that received more ink than any other in the press during the epidemic was that of the tenement houses or conventillos that provided a source of inexpensive housing for immigrants and the working-class of Buenos Aires. During the initial stages of the epidemic, $L a$ Prensa encouraged landlords to improve their properties by adding more windows for ventilation, increasing the number of latrines, and using better building materials. In simple words it was made clear that, "There is a great urgency to put [the conventillos] in a condition that will not threaten hygiene, public security, or the public moral." At the same time, the press reminded landlords that fines would be issued to those who intentionally filled rooms to over-crowding. ${ }^{114}$ By April, a tone of frustration was evident as articles in the press condemned the increasingly deplorable conditions of the tenement houses and called upon the government to empty the conventillos. ${ }^{115}$

In a similar tone, the daily editorials attacked the parish hygiene commissions, the municipal Comisión de Higiene, and the Consejo de Higiene Pública for what was perceived to be a lack of preparation and overall inefficiency in handling the increasing number of cases of yellow fever. Moreover, and not devoid of political affiliation, the press singled out various prominent officials and scrutinized their response to the plague. Hector Varela, editor of $L a$ Tribuna and an ardent opponent of Emilio Castro filled his columns with fiery rhetoric against the governor and his appointees for failing to deal with the disaster adequately. El Mosquito, La Prensa and La Nación each printed articles expressing frustration with the number of governing officials who had deserted their posts while the pestilence raged in the city. In its sarcastic and

114. La Prensa, February 27, 1871. Overcrowding was also a problem in the public jails and in local hospitals as well. La Prensa claimed that cells built to accommodate ten to fifteen people were being used for up to thirty inmates. Like the conventillos, the jails facilitated the rapid spread of disease and the press argued that prisoners should be moved out of the city limits. See La Prensa, March 14, 1871.

115. La Prensa, April 10, 1871. 
humorous tone, El Mosquito under the direction of its editor, Enrique Stein, noted that, "three judges of the Tribunal Superior, understanding the importance at this moment to focus on the issues of health before matters of jurisprudence, have done well in abandoning the juris to conserve the prudence by retiring to the countryside."116 Likewise, President Domingo Sarmiento was frequently criticized for his decision to leave the city and establish a residence in Mercedes during the outbreak. Disparagingly, La Nación reminded its readers that, "the epidemic is Buenos Aires' problem and as such the constitution dictates that [the federal government] abstain from participating in local affairs" and in compliance to that mandate, Juan de Afuera (nickname given to the San Juanino Sarmiento) had abstained. In a more cynical tone, the article continued with the accusation that had the epidemic occurred in La Rioja or Tucumán, the administration would have likely sent federal troops to assist with the disaster. But, the author claimed, since the outbreak occurred in Buenos Aires "where there is not much to win and perhaps more to lose" the government "ascends to the regions of nationalism" forgetting the effects that will be caused to the nation. ${ }^{117}$ More direct and poignant, a scathing article entitled "The Fleeing President" used words such as "cowardice" and "mediocrity" and accused the President of "turning his back" upon those that he abandoned. How should such a leader be dealt with? The article advised, "he is not tried in court, [but rather he is to be] shot in the back."118 Amidst the criticism, the press also reminded its readers of their responsibility in light of the epidemic. In one article, La Prensa identified the municipal government as one of the most important powers exercised by the rule of the people and as such underscored the prerogative of each neighborhood to name delegates as municipal representatives. The article continued with the following commentary:

116. El Mosquito, March 12, 1871, Año VIII, numero 423.

117. La Nación, April 4, 1971.

118. La Prensa, March 24, 1871. 
Foreigners also have the right to participate in municipal affairs and this association of residents, that disregards nationality, is one of the first means by which the industrious immigrant forgets his homeland and establishes roots among us. Notwithstanding, it is important to remember that foreigners refrain more than is necessary from exercising their municipal rights in our cities and become indifferent to the administration of their own interests and care of their own hygiene.

The article continued, "Let us dignify the Municipality, let us identify ourselves with it, let us encourage all honorable citizens, foreigners or sons of the country, men of pure and upright hearts to serve within its midst and then we will see how the Municipality will become the true government of the people for the people". ${ }^{119}$ Unfortunately, the significance of the La Prensa's words were lost in the whirlwind of devastation that encompassed the city and the inhabitants of Buenos Aires were less concerned at the time about political representation as they were about immediate relief from the epidemic.

Convinced that the government institutions were unable to adequately deal with the disaster, the press called upon its readers to organize a popular response to the epidemic. In an article entitled "Public Hygiene," La Prensa reminded its readers of the vital assistance provided by neighborhood commissions during the outbreak of cholera in 1867-1868 at which time the people of Buenos Aires assumed the duties of an inefficient municipal administration as "active agents" in caring for the sick and afflicted. The article further called upon porteños to become "enthusiastic proponents" of any initiative that might spare the city from the looming threat and pleaded that they do so before the disease was literally at their doorstep. ${ }^{120}$ Regrettably, the call to action was ignored and only revisited a month later when Evaristo Carriego, grandfather of the Argentine poet memorialized by Jorge Luis Borges, urged Hector Varela as editor of the $L a$

119. La Prensa, February 4, 1871.

120. La Prensa, February 6, 1871. 
Tribuna to circulate the idea of forming a "humanitarian association with the design of providing assistance and means of healing to the indigent people attacked by the epidemic." ${ }^{21}$ Immediately the cause was supported by Manuel Bilbao in La República and within days the editors of Buenos Aires' newspapers were united in the effort. On March 10, representatives from the porteño press met at Carriego's home to determine a course of action. Included among those present were the following individuals: Aristóbulo del Valle (El Nacional), José María Cantilo (La Verdad), Domingo César (Intereses), José Camilo Paz (La Prensa), Emilio Onrubia (El Fénix), Bartolomé Mitre y Vedida (La Nación), Manuel Bilbao (La República), Hector Varela (La Tribuna); and representing non-Spanish language papers: Alfredo Ebelot (La Republicain), E. Mulhall (The Standard), Antonio Gigli (Eco d'Italia), Leon Walls (Le Courrier), Basilio Cittadina (La Patria degli Italiani), and Adolfo Korn (Freie Presse). The group proposed that a general meeting of the population be held in the Plaza de la Victoria on March 13 at which time the Comisión Popular de Salud Pública would be presented to the people for their approval.

On the given date, nearly 9,000 people crowded into the plaza and at noon the sound of canons called the meeting to order. Arm in arm, the group marched from the offices of $L a$ República on Bolivar street towards the cathedral where Hector Varela, Manuel Argerich, Carlos Guido y Spano, and Basilio Cittadini each addressed the multitude and reiterated the urgency for the people to take action and defeat the epidemic. Organizers of the meeting further requested that the people ratify the names of the men that would form the membership of the Comision Popular which, in addition to the original group of journalists that met at Carriego's residence, consisted of the following individuals: Adolfo Alsina, named as an honorary president of the Comisión Popular, vice-president of the republic and ardent proponent of the Unitarianist movement that pushed for a centralized government in Buenos Aires; Dr. José Roque Pérez, respected attorney known for his assistance and leadership during the cholera epidemic of 1867-1868; Francisco López Torres, journalist and legislative representative in the state government; Bernardo de

121. Scenna, Cuando murió Buenos Aires, 1871, 232. 
Irigoyen, future Minister of Foreign Relations under President Nicolás Avellaneda, governor of Buenos Aires from 1898 to 1902, and national senator from 1902 until his death in 1906; Manuel G. Argerich, medical doctor/attorney remembered for his benevolence and care towards the poor during the aforementioned outbreak of cholera and subsequent epidemics including the outbreak of yellow fever in 1871 in which he contracted and succumbed to the disease; Juan Carlos Gómez, Uruguayan attorney/journalist with strong ties to other members of the Buenos Aires press; Cosme Mariño, journalist for La Prensa and loyal devotee to Sarmiento; Matías Behety, poet and attorney who worked for a time under the direction of Manuel Quintana, future president of the republic; Lucio V. Mansilla, Nephew of Juan Manuel de Rosas, military official during the War of the Triple alliance, author, journalist and respected statesman; Carlos Guido y Spano, poet/author who was influenced by and extolled Romanticism in Argentine literature; Tomás Armstrong, Irish immigrant to Argentina in 1817, banker, land owner, industrialist and member of the Argentine elite; Gustavo Nessler; and Ovidio Lagos, author and journalist who advocated the cause of the Federalists and the creation of a confederate Argentina. ${ }^{122}$ Collectively, the group of journalists, lawyers, poets, medical doctors, politicians, Masons, and priests that formed the Comision Popular exemplified some of the brightest and most talented minds of the period loosely bound together to provide care and respite to the poor and provide assistance to those most affected by the epidemic. Individually, the men represented the entire spectrum of political

122. Scenna, Cuando murió Buenos Aires, 1871, 232-37. Subsequently, other members were added to the group beginning at first with Manuel Quintana, Alberto Larroque, Domingo Dalmonte, Pablo Ramella, Pedro Uzal, and Carlos A. Paz. On March 28 the Comisión was expanded to include the following members: Juan Argenti, Manuel Argenti, Pascual Barbaty, Guillermo Gowland, Pedro Gowland, Ramón Viñas, Fernando Dupont, Particio José Dillon, J. Meyans. In early April, Fernando Dupont left for Europe and was replaced by David Lewis who served for just a few days eventually resigning so as to attend other duties. Lewis was replaced by Florencio Ballesteros. See Scenna, Cuando murió Buenos Aires, 1871, 256-59. 
ideologies and loyalties that characterized nineteenth-century Argentina and which would eventually lead to the demise of the Comisión Popular.

On March 14, the day after the spirited meeting in the Plaza Victoria, the formal organization of the Comisión Popular continued as thirty of the thirty-two members met at the home of Hector Varela to elect a governing board and outline their initial intentions. Fearing that Varela's known biases against Castro and unwavering support for Sarmiento would cast a shadow of doubt or public distrust on the sincerity of the institution, members of the Comision elected Dr. José Roque Pérez as president and Varela as the vice-president. In the same meeting, Mariano Billinghust was named as the treasurer and Matías Behety and Emilio Onrubia were designated as secretaries. ${ }^{123}$ Following the appointment of the presiding officers, the members resolved to enumerate and carry out a series of objectives that reflected the "popular sentiment" that led to the establishment of the Comision. Foremost on the list was the desire to meet with the governor and with the president of the republic to urge that further action be taken to limit the continual spread of the disease. Specifically, the delegation assigned to meet with Castro was to request that his administration increase efforts in the sanitation of the Riachuelo, the perpetual epicenter of disease and decay. Those meeting with Sarmiento would appeal for a prohibition on immigration to Buenos Aries during the outbreak. Second, the Comisión concluded that it was necessary to communicate to the Comisión Municipal and the chief of police the disposition of the Comision Popular to jointly assist with any and all efforts to combat the epidemic. Furthermore, it was decided that the parish hygiene commissions were to report to the Comisión to ensure that the group was adequately informed as to the extent of the disease in the various neighborhoods. Based on these reports, the Comisión would dispatch its own inspection team to evaluate the severity of the situation and then determine what additional steps were needed. Finally, it was decided that each of the newspapers would run two columns: one to advertise that the Comisión was willing to hire male and female nurses at a rate of one hundred pesos per day and the other to

\section{Ruiz Moreno, La peste histórica, 127.}


publish the names and addresses of the members of the Comisión Popular for those who needed to depend on their services. ${ }^{124}$

Having organized its internal leadership and thereafter agreeing upon the priorities that required immediate attention, the Comisión Popular met on March 15 to draft a letter to the people of Buenos Aires soliciting the "material and moral support" of those that were able to help accomplish the "sacred and arduous mission" to be carried out by the Comisión. The document reminded porteños of the "terrible plague" that continued to take the lives of hundreds of victims each day while simultaneously leaving those who survived in a state of misery and desolation. Calling for collective action, the letter read:

Will the support that is needed be denied? To think of such would be a slap in the face to such a generous and magnanimous people. . . Where there is a suffering cry, we will be there to console the pain. With the help that we are requesting we can clothe the naked, give drink to those that thirst, and bury the dead. People of Buenos Aires! The Comisión de Salubridad asks for your generosity to carry out this mission of charity. If everyone contributes a little we will have much. The poor man who gives a peso is no less than the rich man who gives thousands, both lay claim to the gratitude that will come from those who benefit from their kindness. ${ }^{125}$

Printed in La Nación the following day, the emotion-filled petition was successful in motivating the public to contribute financial resources to the Comisión Popular. In total, $\$ 3,700,000$ pesos were collected during a three month period and used to fund the Commission's activities. ${ }^{126}$

The carefully articulated letter served yet another purpose in addition to that of mobilizing the generosity of the porteño masses. Clearly understanding the power of the press,

124. La Nación, March 15, 1871.

125. La Nación, March 16, 1871.

126. Scenna, Cuando murió Buenos Aires, 1871, 274. 
the Comisión composed the document with the intent to influence public opinion and thereby solidify its position vis-a-vis municipal and state institutions already engaged in the fight against the epidemic. In the words of the letter:

Things can not continue as they are, at least that is the understanding among those that form the Comisión de Salubridad. That is the understanding of the public who have honored us with their trust. The current endeavors of the authorities are insufficient to remedy the terrible ills that weigh upon our society, and for this reason we offer our loyal and unbiased services. It is not our intent to limit the actions of any group nor to claim authority that does not belong to us. Unfortunately, the parish commissions that have worked and continue to work with such noteworthy zeal to alleviate those that suffer will never accomplish what is required without the assistance that we have come to offer: strong arms, abundant resources, and all that is necessary to realize the goal which is in sight. . . We are here to fill the void. ${ }^{127}$

In these brief sentences, carefully situated within a plea for charity and benevolence, the Comisión asserted its authority and postured itself as the only entity prepared to fill the perceived void. Somewhat patronizing, the Comisión recognized the "noteworthy zeal" of the parish health commissions but was quick to point out that the commissions had proven themselves incapable of handling the current situation. Moreover, unlike the inept government administered departments and councils, the Comisión, created and upheld by the voice of the people, had access to the necessary manpower and financial support to confront and remedy the "terrible ills" caused by the outbreak.

The self-proclaimed preeminence of the institution was further manifested when, at the same meeting, the Comisión decided to write a second letter directed to the parish hygiene commissions outlining the procedure by which they were to report the nature and extent of the

127. La Nación, March 16, 1871. 
epidemic within their geographical boundaries. ${ }^{128}$ Moreover, and equally presumptuous, the members of the Comision organized themselves into six subcommittees with two of the committees assuming responsibilities already being carried out by the Consejo de Higiene Pública and the Comisión Municipal. The Hygiene Committee, for example, was tasked with neighborhood inspections, home evacuations, and disinfections - activities that were under the jurisdiction of the Consejo and which had been dutifully implemented since 1867. Similarly, a Medical Committee was created to supervise personnel and ensure that doctors and nurses were distributed as needed into one of four districts of the city. The formation of the committee overlooked the fact that medical professionals in Buenos Aires were loosely governed by the municipal authorities in cooperation with the Consejo de Higiene and that all assignments corresponded to one of the pre-existing parishes and not an unfamiliar district delineated by the Comisión Popular. Commenting on these actions, the prominent Argentine physician, Dr. José Penna, would later note that the Comisión Popular "moved forward with its own agenda" completely detached from the Comisión Municipal and its parish medical teams that were "conveniently integrated" and "perfectly distributed" throughout the city and which honorably performed the duties of their office by assisting and comforting the families besieged by the plague. ${ }^{129}$

The crafty maneuvering by the Comisión Popular did not go unchecked and was met by immediate responses from government authorities and the medical community. On March 13, the same day that the Comisión was formed, Governor Castro issued a declaration assuring the people that their concerns about the epidemic were being heard and that the government was doing everything within its means to confront the disease. To emphasize this point, Castro

128. Perhaps it comes as no surprise that the presidents of the parish commissions ignored the request of the Comisión and refused to adhere to the instructions provided in the circular. See Scenna, Cuando murió Buenos Aires, 1871, 248.

129. Penna, "Estudio sobre las epidemias," 35. 
reminded porteños of the varied initiatives undertaken by the state and listed several of the most relevant including the creation of the new cemetery in Chacaritas as well as the provision of transportation and temporary housing to the poor who fled the city. Furthermore, the governor acknowledged that each of the undertakings was done in cooperation with the Comisión Municipal and complemented the members that governing board who had "consecrated themselves completely to the delicate affairs associated with protecting the public health of the people." Finally, Castro concluded his public announcement with the invitation for the people to trust the authorities, remain calm, and maintain order and further cautioned that "chaos [desorden] would only increase the fruitless misfortune all around us." 130 Two weeks later, in an article regarding his appointment to the Comisión Municipal, General Bartolomé Mitre, the former president of the republic levied a similar blow to the Comision Popular with the accusation that the organization was "assuming the duties of the municipality or the state." For Mitre, the Comisión Popular should attend to the personal needs of the unfortunate victims of the epidemic and "leave everything else to the care of the corresponding authority."131 Similarly, the Revista Médica Quirúrgica, expressing the voice of porteño physicians, observed that the Comisión Popular "independent of all other agencies" would provide a "valuable service" if it directed its resources to the creation of a lazaret or quarantine station. With such a shelter, the Comisión Popular could provide for the families of the poor and by doing so have "immediate and more positive results" than by competing with the Consejo de Higiene and the Comisión de Higiene. ${ }^{132}$

Perhaps the most contentious issue between the Comisión Popular and the two government agencies was the struggle that ensued over the administration of the city's physicians. To be certain, the chaotic nature of the epidemic produced mishaps even between the Comisión de Higiene and the Consejo de Higiene. For example, in March, the Comisión de

130. Ruiz Moreno, La peste histórica, 264.

131. La Nación, March 29, 1871.

132. Revista Médico Quirúrgica. 
Higiene - responding to vacancies or the need for additional medical professionals — reassigned the cadre of doctors to the various parishes. Several days later, the Consejo de Higiene, without notifying municipal authorities, issued a circular redistributing medical personnel to the city's parishes. The action elicited a strong letter from the Comisión de Higene to the Consejo de Higiene and the two agencies immediately convened to rectify the problem. On March 31, a final decree, signed by the governor and blessed by the municipal board, designated the physicians that would serve in the different parishes. More importantly, the statute subordinated all doctors in the city to the Consejo de Higiene thus establishing the preeminence of the Consejo in relation to the other councils and commissions. ${ }^{133}$ In defiance, the Comisión Popular directed the handful of doctors under its jurisdiction to ignore the order issued by the governor. However, the Consejo de Higiene continued to exert its influence and legitimacy and in early April refused to provide medical licenses to local and foreign doctors employed by the Comisión Popular who had either failed to renew their credentials or "had not made the effort. . . to appear before the Medical Board to prove their competency." 134

In addition to its troubled relationship with the Comisión Municipal and the Consejo de Higiene, the Comisión Popular was fraught with internal fissures that were created by the differences of opinion and animosity that existed among its members. Unquestionably, the tension within the Comisión Popular was evident from the day that the charitable organization was established but was kept in check by the leadership of Dr. José Roque Pérez. However, in late March when the respected Roque Pérez succumbed to yellow fever, the dynamics of the commission changed drastically and exposed the superficial cohesiveness of the group. Within days of his appointment as president of the Comisión Popular, the impulsive Hector Varela expelled Manuel Quintana, Gustavo Nessler, and Basilio Cittadini on the pretext that they had missed three meetings. In truth, Quintana claimed that he was dismissed because he had refused

133. Scenna, Cuando murió Buenos Aires, 1871, 262-67.

134. Revista Médico Quirúrgica año VIII, no. 5 (8 June 1871). 
to support the political maneuverings of Varela in an earlier attempt to be appointed to the Comisión Municipal; Nessler and Cittadini on the other hand were removed because of their friendship and association with Quintana. ${ }^{135}$ On April 15, in what La Prensa referred to as a "tempestuous meeting, divided by political ideas" several other members of the commission resigned in protest and amidst the shouting Varela's closest allies were given charge over the various committees. ${ }^{136}$

As the Comisión Popular continued to unravel over following weeks, the newspapers that had initially called for the creation of a popular commission directed some of their harshest words towards Varela and his supporters. In its attack, La Prensa distinguished between those members of the Comisión who tirelessly assisted the victims of epidemic and the "ambitious politicians" whose actions merited "public shame" and confirmed what had been suspected from the beginning. ${ }^{137}$ Lucio Mansilla, a close friend of Quintana, likewise noted that the idea to create the Comisión Popular was "inspired" and lauded its desire to "save the poor from yellow fever." For Mansilla, the noble cause was sabotaged by a small group whose intent was to use the commission to "overthrow the Comisión Municipal and the government of Mr. Castro, if the opportunity presented itself." 138 Finally, an article published in La Nación simply called the actions within the Comisión "a big, sad scandal."139

\section{Conclusions}

On May 11, 1871 the members of the Comisión Popular met for the last time. Unlike the initial meeting in the Plaza Victoria two months earlier where thousands gathered to listen to the impassioned speeches of key organizers of the movement, the final reunion was a somber event

135. Scenna, Cuando murió Buenos Aires, 1871, 397.

136. La Prensa, April 17, 1871.

137. La Prensa, April 17, 1871.

138. La Prensa, April 19, 1871.

139. La Nación, April 23, 1871. 
with only the remaining twenty members in attendance. Varela addressed the group and praised the efforts of the commission after which the names of members of the Comision who had died during the epidemic were read. As its last official action, the Comisión drafted a final manifesto that concluded with the words, "Our mission has ended!"140

Throughout the epidemic, the press not only identified the events that marked each passing day but defined and redefined its role in porteño society. Its concern for the general hygiene and sanitation of the city shaped debates that would characterize the developments of subsequent decades and fostered the continued development of the public sphere in Argentina. Moreover, the discourse of the press during the epidemic provides some insight as to how it perceived itself in relation to the government structures and the population of the city. On December 31, 1870 an article in La Prensa declared that its mission in the coming year was to direct the "public conscience" as the "defender of the people" and as the "quarreling voice of the community." the epidemic progressed, the perceived inefficiency of the government institutions motivated the press to organize a popular movement that led to the formation of the Comisión Popular.

However, throughout the epidemic, the press periodically grappled with the issue that pitted the rights of the individual and against the well-being of the community as a whole. As such, the overall tone of the daily columns began to change as the editors realized that in order to prevent future disasters, it would be necessary for the municipal and provincial governments to carry out measures less than favorable to the general public. In an article entitled "Individual liberty, the press, and hygienic reforms" La Prensa declared that it was time to take a more noble and elevated path and no longer be the violent whip against the government. In short it was time to "submit to authority" and sacrifice "that which we call our individual liberty, rights, and personal

140. Scenna, Cuando murió Buenos Aires, 1871, 416.

141. La Prensa, Dec. 31, 1871. 
guarantees." 142 Hearkening back to a previous article, La Prensa declared that, "[individual] liberty has its limits when in being exercised it infringes on the interests of a larger group and especially when it conflicts with the interests of the entire community." ${ }^{143}$ In matters of disease and hygiene, instead of seeing itself as the defender of individual rights, the press perceived its role as the guardian of the Supreme Law [Ley Fundamental] and the public liberties that necessary for the modernization of the nation.

Table 2.1

Daily number of deaths: March - May, 1871

142. La Prensa, May 5, 1871.

143. La Prensa, February 27, 1871. 
March

$\begin{array}{rrrrrr}\text { Day } & \text { Deaths } & \text { Day } & \text { Deaths } & \text { Day } & \text { Deaths } \\ 1 & 44 & 11 & 139 & 21 & 152 \\ 2 & 40 & 12 & 137 & 22 & 160 \\ 3 & 38 & 13 & 170 & 23 & 150 \\ 4 & 44 & 14 & 161 & 24 & 170 \\ 5 & 47 & 15 & 170 & 25 & 219 \\ 6 & 102 & 16 & 193 & 26 & 231 \\ 7 & 112 & 17 & 195 & 27 & 310 \\ 8 & 112 & 18 & 204 & 28 & 337 \\ 9 & 126 & 19 & 150 & 29 & 280 \\ 10 & 128 & 20 & 165 & 30 & 301 \\ & & & & 31 & 222\end{array}$

April

$\begin{array}{rrrrrr}\text { Day } & \text { Deaths } & \text { Day } & \text { Deaths } & \text { Day } & \text { Deaths } \\ 1 & 258 & 11 & 361 & 21 & 105 \\ 2 & 318 & 12 & 427 & 22 & 129 \\ 3 & 345 & 13 & 293 & 23 & 89 \\ 4 & 400 & 14 & 276 & 24 & 95 \\ 5 & 314 & 15 & 263 & 25 & 104 \\ 6 & 324 & 16 & 249 & 26 & 130 \\ 7 & 380 & 17 & 228 & 27 & 153 \\ 8 & 430 & 18 & 203 & 28 & 161 \\ 9 & 501 & 19 & 171 & 29 & 116 \\ 10 & 503 & 20 & 153 & 30 & 85\end{array}$


May

$\begin{array}{rrrrrr}\text { Day } & \text { Deaths } & \text { Day } & \text { Deaths } & \text { Day } & \text { Deaths } \\ 1 & 117 & 11 & 24 & 21 & 15 \\ 2 & 71 & 12 & 18 & 22 & 25 \\ 3 & 66 & 13 & 31 & 23 & 21 \\ 4 & 47 & 14 & 21 & 24 & 24 \\ 5 & 38 & 15 & 21 & 25 & 15 \\ 6 & 42 & 16 & 13 & 26 & 10 \\ 7 & 33 & 17 & 17 & 27 & 4 \\ 8 & 27 & 18 & 21 & 28 & 16 \\ 9 & 32 & 19 & 17 & 29 & 6 \\ 10 & 23 & 20 & 25 & 30 & 6\end{array}$




\section{CHAPTER 3}

\section{Metaphors and Public Space \\ Introduction}

On June 6, 1887 the Concejo Deliberante or city council of the Municipality of Buenos Aires authorized the preparation of a general census and directed that it specifically discuss the population, commerce, infrastructure and industry of the metropolis. ${ }^{1}$ Published two years later, the census included an extensive section on the public spaces of Buenos Aires. In the introduction to the section on parks and plazas, the document read:

The city has for its relief twenty plazas, gardens and parks, perfectly cared for by the Municipality that serve as lungs and recreational spaces for its inhabitants... [These spaces] are true oasis where all social classes of the population are able to find delightful scenes and clean air. ... They are lovely promenades, decorated with varied structures and lush vegetation; without question they are comparable to those found in the most

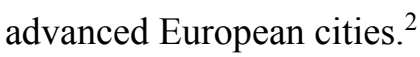

1. MCBA, "Memoria de la Intendencia Municipal de la Capital de la República Correspondiente a 1887, Presentada a H. Concejo Deliberante" (Buenos Aires, 1888), 372.

2. Municipalidad de la Ciudad de Buenos Aires, "Censo general de la población, edificación, comercio é industrias de la Ciudad de Buenos Aires, levantado en los días 17 de agosto y 15 y 30 de setiembre de 1887" (Buenos Aires, 1889), 52. 
Though brief, such language provides valuable insight to the importance and purpose of public spaces in the governing elite's efforts to modernize fin de siècle Buenos Aires. Influenced by the hygienist rhetoric of the period, public green spaces were designed to improve the health of porteños of all social classes by providing respite from the unsanitary conditions found in the city. Inherent in this thinking was the understanding that a healthy population was an indication of progress, that limited public infrastructure and high mortality rates denoted degeneration and backwardness. The governing elite believed that European influenced parks and plazas conveyed culture and modernity. A redesigned urban landscape was, therefore, a means by which to erase the colonial and barbaric past of the nation and civilize its inhabitants.

To this end, the notions of hygiene and nation-building were played out in the transformation of Buenos Aires' open spaces. Yet, contrary to the discourse of modernization, the hygienic benefits and civilizing aspects of public green spaces were applied in limited fashion, primarily to the city's northern neighborhoods, disproportionately benefiting elite residents. Furthermore, the development and enhancement of urban open spaces created public arenas that increased the visibility of deviant behaviors which were deemed contrary to the ideals of order and progress that defined a modern Argentina. Considering these ironies, the park movement in Buenos Aires points to the liberal reforms and positivist influenced policies that directed the urban metamorphosis of the late nineteenth and early twentieth centuries. In doing so, it highlights the significant shortcomings of these agendas and their enduring legacy on the formation and development of the state.

This chapter will trace the development of Buenos Aires' urban green spaces between 1870 and 1910. During these four decades, Buenos Aires solidified its position as the cultural, economic and political hub of the nation, indeed claiming, in this regard, South American leadership. Moreover, the period was marked by unprecedented demographic and physical growth that redefined the city's social and spatial configurations. Amidst these changes, the governing elite carried out an ambitious campaign to improve existing public spaces and lay out 
new parks, plazas, boulevards, paseos and other open spaces to improve the health of its inhabitants and provide a Europeanized gloss to the city. As part of the discussion on the hygienic and civilizing aspects of public spaces, specific attention will be given to the creation of and subsequent improvements to the Parque 3 de Febrero and the Jardín Zoológico in the well-heeled Palermo neighborhood. The park and its zoo are useful for analysis in that the spaces embodied the ideas and ambitions of the "Generation of 1837" and the "Generation of 1880 "- the two cohorts of intellectuals, social critics and policy makers who were primarily responsible for the liberal legislation and material progress that defined Argentina's transition into a modern nation. In recent years, Argentine historians and geographers have turned their attention to the Parque 3 de Febrero and other public spaces in Buenos Aires. ${ }^{3}$ Less has been written about the city's zoo and its contribution to the formation of an Argentine identity.

A discussion on the urban green spaces of Buenos Aires cannot be undertaken without reference to the metaphors used in relation to the spaces. Metaphors were a defining characteristic of the elite discourse that directed development and modernization in nineteenth-century Buenos Aires. Political speeches, daily conversations and printed literature frequently made reference to the arteries, nerves, heart and other physiological analogs to the metropolitan infrastructure. Particularly common was the metaphor of the lung and its connections to urban green spaces. Such metaphors were sure to conjure images that resonated with a population confronting unsanitary living conditions and heartbreaking disease. Much more subtle was the metaphor of the park itself. During the period under consideration, Buenos Aires' public green spaces became

\section{Berjman, "Los espacios verdes de Buenos Aires"; Berjman, Plazas y parques de Buenos} Aires; Gorelik, La grilla y el parque; Diego Armus, "La idea del verde"; Jorge F. Liernur and Graciela Silvestri, El umbral de la metrópolis. Transformaciones técnicas y cultura en la modernización de Buenos Aires (1870-1930) (Buenos Aires: Sudamericana, 1993); Radovanovic, Buenos Aires: Avenida de Mayo. 
the metaphors of culture and modernization. Influenced by French elements of design, the parks and plazas were visible signs of the nation's progress and advancement.

Interest in, and an attempt to, understand the problematic nature of metaphors has made its way into academic scholarship for centuries. In fact, it is widely held that the ideas developed by Aristotle in his works Poetics and Rhetoric established the parameters that continue to frame current discussions and debates on the topic. ${ }^{4}$ Of the Aristotelian influence, Umberto Eco declared, "of the thousands and thousands of pages written about metaphor, few add anything of substance to the first two or three fundamental concepts stated by Aristotle." Challenging this claim is a growing body of literature in the disciplines of linguistics, psychology, literature and philosophy. Pertinent to the ideas developed in this chapter, new models based on cognitive theory and developmental psychology are also useful and indicate that metaphors are pervasive, not just in language, but also in the thoughts and actions involving everyday life. ${ }^{6}$ In simplest

4. John Kirby, “Aristotle on Metaphor,” The American Journal of Philology 118, no. 4 (Winter 1997): 518; Marsh H. McCall, Jr., Ancient Rhetorical Theories of Simile and Comparison (Cambridge: Harvard University Press, 1969); Jacques Derrida, Margins of Philosophy, trans. Alan Bass (Chicago: Chicago University Press, 1982); Paul Ricoeur, The Rule of Metaphor: Multi-Disciplinary Studies of the Creation of Meaning in Language, trans. Robert Czerny (Toronto: University of Toronto Press, 1977); Paul Ricoeur, “The Metaphorical Process as Cognition, Imagination, and Feeling," Critical Inquiry 5 (1978): 143-59; Pierre Swiggers, "Cognitive Aspects of Aristotle's Theory of Metaphor," Glotta 62 (1984): 40-45; David J. Furley and Alexander Nehamas, Aristotle's Rhetoric: Philosophical Essays (Princeton: Princeton University Press, 1994); Liselotte Gumpel, Metaphor Reexamined: A Non-Aristotelian Perspective (Bloomington: Indiana University Press, 1984).

5. Umberto Eco, “The Scandal of Metaphor,” Poetics Today 4 (1984): 88.

6. George Lakoff and Mark Johnson, Metaphors We Live By (Chicago: University Chicago Press, 1980); Max Black, Models and Metaphors (Ithaca, New York: Cornell University Press, 
terms, students in these disciplines recognize "the essence of metaphor as understanding and experiencing one kind of thing in terms of another." This understanding or experiencing is carried out through "asymmetrical analogies" as the properties of one concept are applied to another and can not be reversed. In cognitive psychology, this process of "mapping" employs metaphors as tools of "mental economies" and is a way making the unfamiliar familiar. ${ }^{8}$ As such, meaning is often based on the context in which the metaphor is used. ${ }^{9}$

Historians, geographers, and students of political science have only recently moved towards metaphor as a focus of study or as a tool of analysis in their scholarship. ${ }^{10}$ In this body

1962); Andrew Ortony, Metaphor and Thought (New York: Cambridge University Press, 1993); Susan Sontag, Illness as Metaphor (New York: Farrar, Straus and Giroux, 1978); Mark Johnson, Philosophical Perspectives on Metaphor (Minneapolis: University of Minnesota Press, 1981); David E. Leary, Metaphors in the History of Psychology (New York: Cambridge University Pres, 1990); David Miall, ed., Metaphor: Problems and Perspectives (Brighton: Harvester Press, 1982); E. R. Mac Cormac, A Cognitive Theory of Metaphor (Cambridge: MIT Press, 1985); Naomi Quinn, "The Cultural Basis of Metaphor," in Beyond Metaphor: The Theory of Tropes in Anthropology, James W. Fernandez (Stanford: Stanford University Press, 1991); Raymond W. Gibbs, The Poetics of Mind: Figurative Thought, Language, and Understanding (Cambridge: Cambridge University Press, 1994).

7. Lakoff and Johnson, Metaphors We Live By, 5.

8. Keith L. Shimko, "Metaphors and Foreign Policy Decision Making," Political Psychology 15, no. 4 (December 1994): 661.

9. Laurence J. Kirmayer, “The Body’s Insistence on Meaning: Metaphor as Presentation and Representation in Illness Experience," Medical Anthropology Quarterly 6, no. 4 (December 1992): 332.

10. Tim Cresswell, "Weeds, Plagues, and Bodily Secretions: A Geographical Interpretation of Metaphors of Displacement," Annals of the Association of American Geographers 87, no. 2 (June 
of literature, metaphors are brought to the forefront and are seen as part of the political process that determines behavior and social norms of conduct. In this regards, "metaphor is not merely an academic device for encouraging new theoretical insights; it is, in fact, material power which is constantly mobilized in everyday life." Furthermore, because metaphorical understanding is more likely to be produced by people in power, metaphors become contested discourses as different groups attempt to establish the appropriate behaviors for a given space. ${ }^{11}$

Metaphors of the Body, Metaphors of Civilization

In Argentina, metaphors figured prominently in the nation-building rhetoric of nineteenth and twentieth century intellectuals and formed likewise a defining characteristic of the porteño press. Within that discourse, Buenos Aires was often portrayed as a living organism and, as an extension of that imagery, various aspects of the city were likened to physical features of the

1997): 330-45; Trevor Barnes, The Logics of Dislocation: Models, Metaphors, and Meanings of Economic Space (New York: Guilford Press, 1996); Trevor Barnes and J.S Duncan, eds., Writing Worlds: Discourse, Text and Metaphor in the Representation of Landscape (London: Routledge, 1992); Mary Lowenthal Felstiner, "Family Metaphors: The Language of Independence Revolution," Comparative Studies in Society and History 25, no. 1 (January 1983): 154-80; Margaret E. Farrar, "Health and Beauty in the Body Politic: Subjectivity and Urban Space" (2000), 1.-23; Mona Domosh, “Those 'Gorgeous Incongruities': Polite Politics and Public Space on the Streets of Nineteenth-Century New York City," Annals of the Association of Geographers 88, no. 2 (June 1998): 209-26; Nan H. Dreher, "The Virtuous and the Verminous: Turn-of-the-Century Moral Politics in London's Public Parks," Albion: A Quarterly Journal Concerned with British Studies 29, no. 2 (Summer 1997): 246-67; Alexandra Minna Stern, "Buildings, Boundaries, and Blood: Medicalization and Nation-Building on the U.S.-Mexico Border, 1910-1930," Hispanic American Historical Review 79, no. 1 (February 1999): 41-81. 11. Cresswell, "Weeds, Plagues, and Bodily Secretions," 334. 
body. ${ }^{12}$ Perhaps one of the most prevalent metaphors in the different texts of the period was the representation of the city's parks and plazas as pulmones or lungs of the growing metropolis. ${ }^{13}$ For example, in 1873, Emilio Bunge, as the President of the Corporación Municipal, used the analogy claiming that Buenos Aires was "diseased, asphyxiated and desperately in need of pure air." For Bunge, urban resuscitation was possible by making continued improvements to existing parks and plazas and by planning for the construction of prospective open spaces that would "enliven the lungs" of the city. ${ }^{14}$ Similarly, Torcuato de Alvear, in his role as the first Intendente of the newly designated national capital, advocated for the construction of parks, plazas, promenades, boulevards, and public gardens that would serve as "lungs for a city whose population would soon number in the millions." ${ }^{15}$ Less concerned about future growth, the Intendente Guillermo Cranwell outlined the recreational, social, and health benefits of open spaces and argued that in comparison to larger, more progressive cities of the world, Buenos Aires was deficiently lacking in "those vital elements appropriately called lungs."16

12. Revista Médico Quirúgica 6 (1869)Buenos Aires: Publicación Quincenal, Órgano de los Intereses Médicos Argentinos, 1869; MCBA, "Memoria de la Intendencia Municipal; Año 1903” (Buenos Aires, 1904), 131.

13. MCBA, "Memoria del Presidente de la Comisión Municipal al Concejo correspondiente al ejercicio de 1880" (Buenos Aires: Imprenta Martin Biedma, 1881), 60; Vicente Quesada, Memorias de un viejo. Escenas de costumbres de la República Argentina (Buenos Aires: Peuser, 1888), 64; Domingo F. Sarmiento, “Arquitectura doméstica," in Obras completas, ed. A. Belin Sarmiento (Buenos Aires: Imprenta y Litografía Mariano Moreno, 1900), 104; Eduardo Wilde, Obras completas (Buenos Aires: Peuser, 1917), 21.

14. MCBA, "Memoria de la Ciudad de Buenos Aires correspondiente al año 1873” (Imprenta Jorge E. Cook, 1874), 5.

15. MCBA, "Memoria 1880," 243.

16. "Memoria de la Intendencia Municipal de la Capital de la República correspondiente a 
The metaphor of the lung was fitting and was sure to have resonated with a population plagued by tuberculosis and other pulmonary disorders. ${ }^{17}$ Estimates indicate that during the nineteenth century, tuberculosis killed between seven to fifteen percent of the population annually. Moreover, the mortality rate for tubercular patients remained surprisingly high throughout the first three decades of the twentieth century. On the disproportionate number of deaths associated with the disease, a leading member of the Organization of the Fight Against Tuberculosis lamented:

All that has been done to combat this modern day scourge is minimal in comparison to what is necessary to defeat it ... thus placing us in the same sad situation . . lacking in social legislation and efficient sanitary organization, lacking in means of treatment, and lacking in an overall plan and direction in fighting the disease." 18

1888, presentada al H. Concejo Deliberante," Memoria Municipal de la Ciudad de Buenos Aires (Buenos Aires: Sud America, 1889), XVCVII.

17. On tuberculosis and other pulmonary diseases in Buenos Aires see Diego Armus, “Consenso, conflicto y liderazgo en la lucha contra la tuberculosis: BuenosAires, 1870-1950," in La cuestión social en la Argentina, 1870-1943, ed. Juan Suriano (Buenos Aires: La Colmena, 2000), 191-216; Diego Armus, “Tango, Gender, and Tuberculosis in Buenos Aires, 1900-1940," in Disease in the History of Modern Latin America: From Malaria to AIDS, ed. Diego Armus (Durham, NC: Duke University Press, 2003), 101-29; Diego Armus, Ciudad impura; Vera Blinn Reber, "Blood, Coughs, and Fever: Tuberculosis and the Working Class of Buenos Aires, Argentina 1885-1915," Social History of Medicine 12, no. 1 (February 1999): 41-79; Vera Blinn Reber, "Misery, Pain, and Death: Tuberculosis in Nineteenth-Century Buenos Aires," The Americas 56, no. 4 (April 2000): 497-528.

18. Gregorio Aráoz Alfaro, "Organización de la Lucha Social Contra la Tuberculosis," La Doble Cruz 1, no. 2 (October 1936): 8-9. 
Affluent porteños with the financial resources to do so traveled to Rio de Janeiro or to the warm, dry climate of Argentina's interior provinces for respite and treatment. Those who could not afford to leave Buenos Aires lobbied for an increased number of parks and argued that, "The neighborhoods that do not have a plaza where one can breathe a little pure air and where it is possible to rest from the asphyxiating atmosphere of an unhealthy dwelling ... will be, without doubt, neighborhoods that are predisposed to tuberculosis."19

On a more general level, reference to the city's parks and plazas as lungs also made sense to porteños witnessing unprecedented demographic growth, increased population density, and an overall spatial transformation of the city. According to the 1869 census records, the city claimed a population of 187,346 residents. In 1887 , the number of inhabitants in the city reached 433,375 representing a 131 percent increase in less than a twenty year period. A summary of the population growth of the city is presented in Table 3.1:

Table 3.1

Population of Buenos Aires, 1869-1914

To be clear, the demographic growth of the city was a result of pro-immigration policies founded on the motto "to govern is to populate" as articulated by Juan Bautista Alberdi, one of the leading figures of the Generation of $1837 .{ }^{20}$ On the basis of this ideology, the Argentine government encouraged European immigration through the Law on Immigration and Colonization passed in 1876 . Subsequently, in 1887 Congress approved a program that subsidized the cost of the trans-Atlantic passage for immigrants. The results of these and other initiatives attracted thousands of immigrants on a yearly basis. Between 1881 and 1890 an estimated 637,667 immigrants made their way to Argentina. Two decades later, from 1901 to

\section{Diego Armus, Ciudad Impura, 50.}

20. Juan Bautista Alberdi, Bases y puntos de partida para la organización de la República Argentina (Buenos Aires: Grupo Editor de America Latina, 1979), 167. 
1910, the number of immigrants would almost double with 1,120,222 foreigners arriving during the ten year period. ${ }^{21}$ Although government sponsored immigration was intended to populate the country's interior provinces, many of the immigrants remained in Buenos Aires or migrated to the city following failed colonization efforts on the country's vast plains or pampas. In census records for both 1887 and 1895, over fifty-two percent of the population of Buenos Aires was foreign born. ${ }^{22}$ As noted in other scholarly publications, the percentage of foreigners was considerably higher if one accounts for the number of children born in Argentina to immigrant parents. $^{23}$

The astonishing influx of immigrants transformed the spatial configuration of Buenos Aires and produced significant changes in the overall composition of the city's neighborhoods. In 1887, corresponding to the demographic growth of the metropolis, the province of the Buenos Aires ceded over 34,000 acres to the federal government thus extending the limits of the municipality to its current boundaries as delineated by the General Paz highway that frames the city. $^{24}$

Image 3.1

Maps of Buenos Aires Corresponding 1870 and 1890

Moreover, the porteño elite, who had traditionally claimed the districts closest to the city center,

21. Samuel L. Baily, "Patterns and Immigrant Assimilation in Buenos Aires, 1882-1923," Hispanic American Historical Review 60, no. 1 (February 1980): 36.

22. Baily, "Patterns and Immigrant Assimilation," 36.

23. See for example James R. Scobie, "Buenos Aires as a Commercial-Bureaucratic City, 18801910: Characteristics of a City's Orientation," American Historical Review 77, no. 4 (October 1972): 1045.

24. Gorelik, La grilla y el parque, 13. 
established new residences to the north of the city in Barrio Norte, Palermo, and Belgrano. Those who were less affluent built modest homes in Flores, Caballito, and other western suburbs. ${ }^{25}$ As a result of this migration, the city's older neighborhoods attracted the newly arrived immigrants who found housing in the conventillos or tenement dwellings. With high concentrations in Socorro, San Nicólas, Monserrat, Balvanera, Concepción and La Boca, the conventillos were notorious for their cramped and unhygienic conditions. One contemporary observer referred to the conventillos as "caves with an exterior appearance of a home" while another reported that the small rooms made it "difficult for the air to circulate." 26

Despite the squalor of the conventillos, the constant arrival of new immigrants created a constant demand for such housing. In 1883 municipal authorities identified 2,074 conventillos representing an increase of nearly 200 tenements from the year before. In comparison, over the next seven years, an average of twenty-five new conventillos were constructed annually, however, the number of occupants living in the dwellings increased by more than thirty thousand during the same period. ${ }^{27}$ Even with the overcrowded conditions, the scarcity of housing made it possible for landlords to charge exorbitant rents and by the mid 1890s unskilled workers were

25. Scobie, Buenos Aires; Charles S. Sargent, The Spatial Evolution of Greater Buenos Aires, 1870-1930 (Tempe: Arizona State University, 1974); Needell, "Rio de Janeiro and Buenos Aires," 536-37; Jeffrey D. Needell, "Optimism and Melancholy: Elite Response to the Fin de Siècle Bonarense," Journal of Latin American Studies 31, no. 3 (October 1999): 553-55.

26. Antonio Zinny, "El cólera morbo no es nuevo en el Río de la Plata," Revista de Buenos Aires 47 (March 1867): 479 cited in Salessi, Médicos maleantes y maricas, 77. MCBA, "Memoria del Presidente de la Comisión Municipal al Concejo, correspondiente al ejercicio de 1882; marzo de 1883" (Buenos Aires, 1883), 221.

27. James A. Baer, "Tenant Mobilization and the 1907 Rent Strike in Buenos Aires," The Americas 49, no. 3 (January 1993): 349; MCBA, "Memoria de la Intendencia Municipal 18901892" (Buenos Aires, 1894), 367. 
paying an average of $44 \%$ of their incomes towards housing costs. ${ }^{28}$ Working-class porteños responded by establishing tenant leagues that quickly garnered the support of socialist and anarchist labor unions who in turn encouraged tenants to refuse to pay rents until landlords acknowledged their concerns. Notwithstanding these efforts, a collective reaction did not coalesce until 1907 when the residents of a conventillo on Ituzaingó street refused to pay an eight peso or $47 \%$ rent increase. Within weeks, the rent strike had spread to other neighborhoods with close to 120,000 people participating in the strike at one time or another. ${ }^{29}$ Throughout the strike, tenants generally "maintained a strategy of passive resistance" and addressed their grievances through written manifestations and petitions. In some instances, however, the strike became brutally violent when tenants clashed with local police to prevent forced evictions. ${ }^{30}$ As with the general strikes of 1902 and 1905, the Tenant Strike of 1907 highlighted the underlying social tensions between the land owning elite and the working class.

In matters of hygiene, municipal authorities also recognized that the flood of foreigners and the overcrowded conditions of the conventillos in Buenos Aires threatened the public health and the overall wellbeing of the city. In his report to the municipal council, Guillermo Cranwell, wrote in 1888:

The ever increasing density of the population requires with greater urgency the need for public spaces that adhere to the universally recognized laws of hygiene and in which

28. Baer, "Tenant Mobilization," 350.

29. Baer, "Tenant Mobilization," 356. A comprehensive study of the rent strike can be also be found in Juan Suriano, La huelga de inquilinos de 1907 (Buenos Aires: Centro Editorial de América Latina, 1983).

30. Ricardo D. Salvatore, "The Normalization of Economic Life: Representation of the Economy in Golden-Age Buenos Aires, 1890-1913," Hispanic American Historical Review 81, no. 1 (February 2001): 27-28. 
people can congregate to breathe clean air. . It is my belief that if Buenos Aires needs paved streets it is also in critical need of plazas and parks that renew the vitality of the body that is weakened by living in cramped quarters; families of modest means that can not afford open and hygienic homes and the more affluent should frequent these spaces with their children and thereby better their health. ${ }^{31}$

Cranwell's statement includes two ideas about parks, plazas and other public spaces in Buenos Aires that were repeated with frequency over the decades. Foremost of concern to Cranwell was the observation that Buenos Aires was deficient in park space based on the ratio of the population to the geographical size of the city. The same apprehension was expressed five years earlier by Torcuato de Alvear who bemoaned the "rapid increase in the population and the growing number of buildings that are constructed day after day in the city's center and in its suburbs." For Alvear, the inevitable physical transformation had to be controlled by a plan that would in part "determine the location of new plazas" in the city's neighborhoods. ${ }^{32}$ Similarly, the porteño press likewise lamented, "the lack of sufficient plazas that serve as conduits that enable the air to reach the furthest corners of this poor city." 33

The second relevant idea in Cranwell's words was the correlation between parks and the health of the city's population. In 1869, the Revista Médico Quirúgica cited the benefits of plazas and referred to them as "large repositories where the air is purified" later to be carried by "those arteries called streets" to the inhabitants of the city. The article further claimed that plazas were

31. MCBA, "Memoria de la Intendencia Municipal de la Capital de la República correspondiente a 1888, presentada a H. Concejo Deliberante" (Buenos Aires: Sud America, 1889), XCVII.

32. MCBA, "Memoria de la Intendencia Municipal de la Ciudad de Buenos Aires correspondiente a 1883, presentada al H. Concejo Deliberante” (Buenos Aires, 1884), 534.

33. El Nacional; October 4, 1884. 
needed so that during non-working hours, "the laborer, artisan, and businessmen could enjoy the benefits of sunlight and expand their lungs that are often weak and tired from breathing so much bad air." ${ }^{34}$ Advocating a similar message, Vicente Quesada, author and co-founder of the Revista de Buenos Aires, underscored the hygienic virtues of urban green spaces not only for adults but for children as well. Quesada thus emphasized the importance of the plazas in that they made it possible to "breathe pure air" and to "carry out exercises that would chase away paleness and strengthen the bodies of young children so often accustomed to being continually confined to their homes." ${ }^{35}$ As a result of these observations, municipal authorities argued that plazas in Buenos Aires needed to be "numerous and well maintained."36 Moreover, Alvear was quick to remind the municipal council that the cost of the parks and plazas was minimal in comparison to the positive benefits of hygiene provided by said spaces. ${ }^{37}$

In addition to the health advantages associated with parks, plazas, and public gardens, the governing elite considered that the transformation of these spaces was necessary in the overall effort to Europeanize the city and thereby convert Buenos Aires into an "emblem of modernization." ${ }^{38}$ Noteworthy also was the belief that public spaces should be the physical manifestation of an "enlightened" population thus demonstrating the culture, sophistication, and "level of advancement" of the city. ${ }^{39}$ Recognizing these ideals, municipal authorities looked for opportunities to create new urban green spaces modeled on the aesthetic elements and principles

\section{Revista Médico Quirúgica, 350.}

35. Vicente Quesada, Memorias de un viejo, 64-65.

36. MCBA, "Memoria del Presidente de la Comisión Municipal al Concejo correspondiente al ejercicio de 1879; febrero de 1880" (Buenos Aires, 1880), 328.

37. Adrián Beccar Varela, Torcuato de Alvear, Primer Intendente Municipal de Buenos Aires (Buenos Aires: G. Kraft, 1926), 203.

38. Needell, "Rio de Janeiro and Buenos Aires," 535; Gorelik, La grilla y el parque, 105. 39. La Nación; August 15, 1894. 
implemented by Baron Georges Eugène Haussman in Paris between 1852 and 1870 under the direction of Napoleon III. Admittedly, the porteño fascination with French design and architecture dated to the early nineteenth century as the newly independent Rio de la Plata attempted to distance itself from its Spanish heritage. Speaking on the subject of public buildings, but equally applicable to urban green spaces, Jacobo Bourdier, a French engineer contracted to study improvements to the Plaza de Mayo in 1916 noted that:

When the nation's institutions tend to erase the last traces of Spanish vassalage, public buildings ought to represent a style other than that of the Goths [Spaniards], because in being monuments, they ought to manifest the type of public sentiment prevalent at the time of their construction. ... This has nothing to do with the dictates of good taste, which might be mistaken, but rather with pragmatic issues, which tend to hit the mark."

Hoping to erase the "traces of Spanish vassalage," the governing elite in Argentina looked to Paris and determined that Buenos Aires, like the French capital, would eventually "possess a park in each of its cardinal points." ${ }^{41}$ To carry out the transformation, government authorities recruited the talent of several generations of French landscape architects or paisajistas to oversee the design, construction, and embellishment of the city's green spaces. ${ }^{42}$ By 1883 , the changes in these spaces were such that one article in the press claimed that Buenos Aires no longer had the "aspect of a great provincial town." Instead, it gave the impression of a "completely different

40. José Antonio Pillado, Buenos Aires colonial (Buenos Aires: Compañía Sudamericana de Billetes de Banca, 1910), 106 cited in Szuchman, "Constructing the City," 208.

41. MCBA, "Memoria 1879," 328; MCBA, "Memoria 1890-1892," 154.

42. On the paisajistas see Berjman, Plazas y parques de Buenos Aires The anti-Spanish sentiment in architecture and the arts during the early nineteenth century is discussed in Szuchman, "Constructing the City,” 206. 
city" that exuded "order and beauty." 43 A similar description four years later, compared the parks and plazas in Buenos Aires to the squares of London and the promenades of Paris and asserted that the public spaces in the Argentine capital were equal to those found in "the most advanced cities of Europe." 44

Finally, the leading thinkers of the Generation of 1837 and the Generation of 1880 asserted that the physical transformation of the public spaces would subsequently induce a change in the "public consciences" of the population. ${ }^{45}$ For example, Nicolás Avellaneda, while serving as a national senator prior to being elected president of the republic, argued that the city's parks and plazas were meant to "soften, improve, purify, and ennoble the sentiments of the multitudes."46 As such, the governing elite acknowledged the usefulness of public spaces in the nation-building process and particularly in the development of shared Argentine identity. With this in mind, Alvear extolled the civilizing virtues of parks and plazas and argued that the public spaces should "conserve in the imagination of our children the glorious work of our fathers." During Alvear's administration, each plaza soon flew the Argentine flag and prominently featured the busts and statues of the "illustrious dead and celebrated names of the past patriots." Moreover, parks were meant to be "educational" and were to serve as places where porteños could "develop their intelligence." 49 At the inauguration of the Parque Patricios-built on the site

43. La Nación, May 8, 1883.

44. Municipalidad de la Ciudad de Buenos Aires, "Censo 1887,, 52.

45. This idea was articulated in a letter from Miguel Cané to Torcuato de Alvear. See Needell, "Rio de Janeiro and Buenos Aires," 526.

46. Congreso Nacional, “Diaro de Sesiones de 1874,” Cámara de Senadores (Buenos Aires, 1874), 165.

47. Beccar Varela, Torcuato de Alvear, 70.

48. Diego Armus, Ciudad impura, 54.

49. MCBA, "Memoria del Presidente de la Comisión Municipal al Concejo correspondiente a 
once occupied by the notoriously unhygienic slaughterhouses-Adolfo Bullrich, the city's intendente from 1898 to 1902 , argued that the park would combat "misery and ignorance." Speaking to the boys from the Correctional Prison for Young Men who had been recruited to construct the park, Bullrich was certain that their "instincts and perversions" would be replaced with "habits of work" as they maintained the park and that they would eventually be "converted into useful citizens for the country and the family." 50

The Parque 3 de Febrero and the Jardín Zoologico

Perhaps more than any other public space in Buenos Aires, the Parque 3 de Febrero and its Zoological Garden were defined by the metaphors of hygiene and civilization that characterized the rhetoric of the late nineteenth and early twentieth centuries. As the city's most expansive urban green space, the metaphor of the lung appropriately imbued the space with the attributes of health and recreation. Moreover, the park was constructed on the land that was once the private residence of the authoritarian governor, Juan Manuel de Rosas, and christened with the date that coincided with his defeat. As such, in name and geographic location, the park became a metaphor of order and progress. Originally conceived by Sarmiento and subsequently enhanced by some of the most influential personalities of the period, the park and the zoo attracted thousands of visitors each year and were thus significant in the overall modernization and cultural advancement of the city.

The creation of the park and the zoo stemmed from an executive decree issued by Sarmiento in 1872 - one year after the devastating and still memorable yellow fever epidemic that plagued the city - and received formal approval by the legislature in 1874 with the passage of Law $648 .^{51}$ In truth, Sarmiento had for some time contemplated and promoted different uses for

1876” (Buenos Aires: Imprenta Nacional, 1877), 176; Berjman, Plazas y parques de Buenos Aires, 79.

50. El Diario; September 11, 1902.

51. Olga Vitali, "El primer zoológico de Buenos Aires," Todo es Historia 19 (September 
Rosas' vacant land in Palermo. While in exile in Chile between 1852 and 1855, Sarmiento authored the pamphlet Plan combinado de educación común, silvicultura e industria pastoril, aplicable al Estado de Buenos Aires in which he articulated the idea of "Quintas Normales" or public gardens for the proper education and training of problematic youth. In essence, the plan proposed that the site be used for the construction of a school, orphanage, and a reformatory where orphans and delinquent adolescents would be taught basic trades and the fundamental principles of agriculture. For Sarmiento, the land was an ideal location in that:

When one dynasty succeeded another in France, political norms allowed the new Emperor to confiscate the property of the fallen monarch and designate it towards rural land banks. When liberty has torn down tyranny among us, the Legislature having reestablished its sovereignty, consecrates the acquired property for the good of the public and for the education of the people, because [in France] where poverty is the greatest evil, here it is ignorance.

In a twisted sort of irony, Sarmiento argued that by building the Quinta Normal in Palermo, the Republic would finally benefit from the same tyrant who had for so long "halted its progress." 52 Upon his return from exile, Sarmiento found little support for the Quintas Normales but was encouraged when in 1858 the first agricultural exposition in Argentina was held in Palermo. Commenting on the exposition, Sarmiento declared that the land that was previously utilized to carry out the "ignorant impulses of a dictator" had finally "found a useful destiny." He further proclaimed:

Palermo will be transformed into a place of public interest, absolving itself from the curse 1986): 38 .

52. Domingo F. Sarmiento, "El proceso de Rosas," in Obras Completas (Buenos Aires: Editorial Luz del Dia), 61. 
that binds it and which condemned it to an inevitable destruction; the monuments of savage tyranny [have been] converted into a Model School and Exposition of Industry as instruments of civilization and progress, thus bringing certain revenge to a people whom he had tried to enslave.

Building once again on the analogy between Rosas and Louis XIV, the ardent opponent of the porteño caudillo claimed that "the semi-barbaric Versailles of our rude tyrant will one day be consecrated for the development of Argentine ingenuity." 53

The idea for a public park eventually materialized during Sarmiento's residence in New England while serving as the Plenipotentiary Minister of Argentina between 1865 and 1868. In his travels in the United States, Sarmiento became familiar with the park movement and followed the ideas espoused by Frederick Olmstead in his reconfiguration of Central Park in New York. Inspired by the debates that proposed new uses and changes in the urban landscape, Sarmiento abandoned the idea of the Quinta Normal and instead promoted the creation of a "parque central" in Buenos Aires. On this subject, Sarmiento wrote,

In light of the impressive development of the city of Buenos Aires, whose suburbs extend from the south to Barracas and reach San José de Flores to the west, the people need at least one park that is equal in beauty and comfort to the Bois de Boulogne, Hyde Park or Central Park in New York; a park not only for the wealthy and foreign visitor, but a park for the thousands of artisans and families that will use it for recreation to improve their health and as a place to rest from their daily activities while surrounded by the wonders of nature and public art. ${ }^{54}$

53. Domingo F. Sarmiento, "Exposición Agricola," in Obras Completas (Buenos Aires: Editorial Luz del Dia), 228.

54. "Proyecto del Poder Ejecutivo," Diario de Sesiones de 1874 (Congreso Nacional, Cámara de Senadores, 1874), 152. 
As the idea of a public park gained momentum, those familiar with the city lauded the benefits of creating an urban green space in Palermo. In a letter to Sarmiento, John Le Long, who in 1850 had served as the French consul to Argentina, wrote, "Soon we will have a magnificent paseo in the city of Buenos Aires. It will be a delightful place, brought about by the benevolence and intelligent foresight of a commission of porteños whose desire it was to provide the people with a place for recreation." ${ }^{55}$ Similarly, the medical physician and hygienist, Eduardo Wilde, believed that it was necessary to transform the land into a "pleasant site that will supply puffs of oxygen to renew our bodies. . . . it is indisputable that every city needs as part of its essential hygiene, the proximity of a forest, a wooded area, a meadow, or simply a place where there are trees."56

Though recreation and hygiene figured prominently in the discourse on the park, public opinion also recognized the space as an instrument in the nation-building process. One senator, José María del Carril, expressed his belief that by creating a park in Palermo and "covering it with flowers" the republic could "erase as with a sponge all the reminders of that infamous tyrant." ${ }^{, 57}$ Similarly, in the discussion on the proposed park in the senate, Nicolás Avellaneda argued that the park would further the cause of democracy and, quoting the President of the Central Park Committee of New York, argued "when our public promenades become more frequented, our elections will become less agitated." ${ }^{58}$ A year later, when the park was inaugurated, Sarmiento reiterated the egalitarian nature and civilizing attributes of the space. In the dedicatory speech, Sarmiento claimed, "Only in a vast, artistic, and accessible park, will the people become a nation; in the park there will not exist, foreigners, nationals, nor plebeians." Furthermore, the Argentine president believed that the benefits of the Parque 3 de Febrero would

55. Berjman, Plazas y parques de Buenos Aires, 43.

56. Wilde, Obras Completas, 21.

57. "Proyecto del Poder Ejecutivo," 165.

58. Congreso Nacional, “Sesión Ordinaria del 20 Junio de 1874,” Cámara de Senadores (Buenos Aires, 1874), 178. 
extend beyond the limits of Buenos Aires and that the park was "a model presented to the people of what the country can become." 59

Upon completion, and as conceived by Sarmiento and others, the Parque 3 de Febrero included extensive trails, two lakes, and dozens of small plazas and gardens designed by prominent paisajistas. Over the next three decades, continued improvements expanded the geographic footprint of the park and by the turn of the century the space had nearly tripled in size. The park was also complimented by the construction of recreational destinations that appealed to the porteño population. For example, the hippodrome, originally built in 1876 and subsequently remodeled based on the Beaux arts style, was extremely popular and continues to be one of the premier venues of its type in the world. Similarly, in 1897, the municipal government authorized the construction of a velodrome for cyclists based on the presumption that the track would "undoubtedly increase the number of visitors to the Park." ${ }^{60}$ Finally, in addition to the recreational uses that defined the space, public art and other cultural artifacts were incorporated into the park. For the governing elite, the history and legacy of the republic was not confined to the lectures of the classroom but rather was found "in the spectacle of daily life [and] in the traditional nomenclature of places." As such, the "heroic memories" of the past came to life in the "commemorative monuments of statues" placed in and around the park. ${ }^{61}$

Perhaps one of the most unique features of the park was the construction of a small zoo open to the public. Ironically, the decision to incorporate a zoo was not a novel idea for the area but rather an extension of Rosas' jardin de fieras that housed a small assortment of birds and animals — including a bear purchased from a gypsy—-that entertained guests at the governor's

59. Domingo F. Sarmiento, "Discurso Inaugural del Parque 3 de Febrero," in Obras Completas (Buenos Aires: Editorial Luz del Dia), 11-13.

60. MCBA, "Memoria presentada al H. Concejo Deliberante por el Intendente Municipal Dr. Francisco Alcobendas; año 1896” (Buenos Aires: Sud-America, 1898), 61.

61. Ricardo Rojas, La restauración nacionalista (Buenos Aires: Peña Lillo, 1909). 
estate. $^{62}$ Upon its completion in 1875 , the zoo in the Parque 3 de Febrero consisted of three swans, a ferret, a guanaco, and a jaguar. In contrast, by 1892, the zoo included over 1,100 "peculiar specimens" from Argentina and other countries of the world. ${ }^{63}$ Commenting on the zoo, Alvear observed:

Our citizens that work all week, need and should have a pleasant place to go on their day off. The wild and penetrating stare of an African lion or of a Bengal tiger, the enormous size of an elephant or the frightening ugliness of a hippopotamus, will awaken the curiosity and provide entertainment for a multitude and children will be delighted by the thousand mischievous actions of a monkey." $" 64$

Adding to the variety of the zoo, patrons also found enjoyment in other attractions including a carousel, animal rides, a miniature train, and a puppet theater. ${ }^{65}$

Though the attractions appealed to patrons, the directors of the facility were quick to point out that the zoo's purposes extended beyond entertainment and recreation. Eduardo Holmerg, the first director argued, "A zoological garden is not a luxury nor is it a vain and superfluous exhibit; instead it amicably compliments the national laws relating to public education." 66 For Holmberg, the zoo was foremost a center of science where the "enthusiast" would find a "sanctuary rich with opportunities for learning." ${ }^{\circ 7}$ Along the same line of thought,

\section{Jardín Zoológico de la Ciudad de Buenos Aires: 110 Aniversario 1888-1998 (Buenos}

Aires: Jardín Zoológico de la Ciudad de Buenos Aires, 1998), 27.

63. Eduardo Sparrach, "Eduardo Ladislao Holmberg: Médico y Naturalista," Fundación Cultural Santiago del Estero (2007).

64. Jardín Zoológico, 28-29.

65. Jardin Zoológico, 38-41.

66. Sparrach, "Holmberg."

67. Jardín Zoológico, 31. 
Holmberg's successor, Clemente Onelli, believed that the zoo was to encourage "education and hygiene" and that the "primary objective" of the facility "consists of cultivating in the people a strong desire to study the natural sciences." ${ }^{\prime 68}$ To promote scientific understanding and to foster communication between zoologists in Buenos Aires and in other parts of the world, Holmberg established the Revista del Jardín Zoológico. First published in 1893, the Revista was printed until 1922 with a total of sixty-eight issues. Likewise, Onelli authored several volumes of Idiosincrasias de los pensionistas del Jardín Zoológico in which we chronicled the behavior and activities of the zoo's animals.

Not to be ignored, the zoo was also a cultural experience that exposed patrons to art and architecture from the great civilizations of the past. During the relocation of the zoo in 1888 to its present-day site at the corner of Avenida General Las Heras and Avenida Sarmiento, Holmberg included in the design several structures with architectural elements from around the world. Thus for example, the elephant pavilion completed in 1903 was a replica of a Hindu temple in Bombay. ${ }^{69}$ Similarly, in 1909 work was completed on a structure modeled after the Temple of Vesta in Rome. The edifice — built for nursing mothers "who demanded the construction of such a space" - was one third the size of the original and was situated in a picturesque area of the zoo amidst a group of conifer and laurel trees. ${ }^{70}$ Both the structures that housed the animals as well as those built for the patrons provided a visual reminder of the progress and advancement of humanity.

Notwithstanding the numerous amenities that characterized Parque 3 de Febrero, the park was often underutilized. In 1882, writing under the pseudonym Lucy Dowling and thus attempting to provide the opinion of a North American traveler, Vicente Quesada observed that

68. Jardín Zoológico, 41,49.

69. Sparrach, "Holmberg."

70. MCBA, "Memoria de la Intendencia Municipal de Buenos Aires correspondiente al año 1909” (Buenos Aires: G. Kraft, 1910), 398. 
"Parque 3 de Febrero is a wonderful paseo but it is vacant every day, only on Sundays and on holidays is there a notable gathering. On another occasion, Quesada wrote:

That the promenades were always empty, caught my attention. I have frequented them at all hours, and never have I seen a child! 'Where are the children?' I asked myself. In the United States and Europe, the public gardens are filled with children; their health requires it to be so. Youngsters need the festiveness of the landscape, the view of the flowers; they need to run under the shadow of the trees, they must leave their homes for the fresh air made possible by the vegetation outdoors. This is the only city where I have not seen children in the public walks." 71

For Quesada, the park was a "required necessity of hygiene" where porteños of all ages and social classes could go to breathe pure air and rest from the pace of the growing city. ${ }^{72}$

Like Quesada, Sarmiento was concerned that the "children do not make it to Palermo" but also noted another problem with the park in that it was "frequented almost exclusively by elegant carriages." As one who had promoted the egalitarian nature of the Parque 3 de Febrero before its construction, Sarmiento worried that the porteños who most needed the park were deprived of its benefits. On this he wrote:

The artisans and mothers with children who do not have transportation are left with merely the knowledge that the park exists. There are in the city one hundred thousand Europeans of all classes and position. In the park it is difficult to find one hundred ... thus proving that they come as poorly educated as we see them here. The Government

71. Vicente Quesada, Memorias de un viejo, 64-64 quoted in Szuchman, Order, Family, and Community, 105.

72. Vicente Quesada, "La Ciudad de Buenos Aires. Apuntes de una Viajera," Nueva Revista de Buenos Aires (1882)Buenos Aires: Peuser, 1882. 
has done its part where it has been possible. The public has done nothing, neither have their practices or customs changed at all or even a little. ${ }^{73}$

For Juan de Cominges, a contemporary of Sarmiento, the reason that the "proletarian classes" did not patronize the park was not because of the distance. Instead he argued that "the first blame should be on their own lack of culture that does not allow them to enjoy the pure happiness that is provided in seeing such beauty." ${ }^{\prime 4}$ The appropriation of the space by the elite, however, did not go unnoticed and at times the subject found its way into the public sphere through the pages of the press. In 1894, La Vanguardia titled one of its articles, "The Monopoly of Air" and criticized the elite for claiming Parque de Palermo as their own and subsequently defended the right of the city's "young girls and shoe shine boys to [breathe] a little air with oxygen." 75

Whether excluded because of distance or as a result of the pretensions of the elite, the poor's limited access to Parque 3 de Febrero cast doubt on the hygienic benefits of the large public park. During the initial debates in the 1870 s, the respected physician and hygienist, Guillermo Rawson, was one of the first to point out that the distance between the proposed Parque 3 de Febrero and the conventillos in the southern neighborhoods failed to address the needs of the city's underprivileged. ${ }^{76}$ Instead, Rawson believed that smaller plazas or squares should be built throughout the city thus extending the benefits of green spaces to more of the population. ${ }^{77}$ As late as 1909 , a topographical study of the capital included in the municipal census noted that Rawson's observation was correct and that the city was "far from having the

73. El Nacional, October 12, 1882.

74. Gorelik, La grilla y el parque, 161.

75. La Vanguardia, May 19, 1894; Ibid, December 7, 1901.

76. Gorelik, La grilla y el parque, 159.

77. Guillermo Rawson, Escritos y discursos, comp. and ed. Alberto B. Martínez (Buenos Aires: Sudamericana de Billetes de Banco, 1891), 123. 
plazas, parks, and paseos that its progress and development demand." ${ }^{, 78}$ For one critic, the high concentration of parks in Recoleta, Barrio Norte, Palermo, and Belgrano in the north of the city was preposterous. Drawing on the metaphor initially used to garner support for the Parque 3 de Febrero, the observant porteño claimed, "the lungs of the metropolis are outside of the body ... the city breathes from the periphery."79

Curiously, in contrast to the general underutilization of the park space, porteños frequented the Jardín Zoológico on a regular basis with thousands visiting the zoo on weekends. ${ }^{80}$ The popularity of the zoo was such that the Intendente Carlos Roseti referred to it as "one of the most important paseos" of the city. To emphasize his point, Roseti asserted that the number of visitors each trimester was equal to one-fourth of the population of the metropolis. ${ }^{81}$ To be certain, the zoo's attendance doubled during Roseti's tenure to over one million annual visits and corresponded to the birth of an elephant on February 23, 1906 that Onelli named Phua Victoria Porteña. The birth was significant in that Phua was one of the first elephants born in captivity and as Onelli declared, "a rare case" and an event that "caused genuine excitement among the entire population of the capital." 82 By 1908, there was a total of 1,090,772 visitors to the zoo-more than twenty percent of which visited during the months of September and November-in

78. Municipalidad de la Ciudad de Buenos Aires, "Censo general de la población, edificación, comercio é industrias de la Ciudad de Buenos Aires, levantado en los días 11 y 18 de septiembre de 1904" (Buenos Aires, 1906), 555.

79. Ezequiel Martínez Estrada, La cabeza de Goliat (Buenos Aires, 1946), 135.

80. MCBA, "Memoria de la Intendencia Municipal de la Ciudad de Buenos Aires correspondiente a 1889, presentada al H. Concejo Deliberante por el Intendente Seeber" (Buenos Aires, 1891), 194.

81. MCBA, “Memoria de la Intendencia Municipal; año 1905” (Buenos Aires, 1906), 93.

82. Clemente Onelli, Idiosincrasias de los pensionistas del Jardín Zoológico: 1908, 1909, 1910 (Buenos Aires: Elefante Blanco, 1999), 42. 
comparison to a population of $1,118,080 .{ }^{83}$ The following year, the number of annual visits reached 1,276,051 of which 29,003 were students that were not charged the ten cent cost of admission. In his report to the municipal government, Onelli claimed that the number of patrons would have likely been higher if it were not for the frequent Sunday rains and the general strike in the month of May that characterized the year. ${ }^{84}$ With so many visitors in one year, Onelli quipped that the "large crowds of people" especially on holidays made the zoo seem small even with its nearly eight kilometers of pathways. ${ }^{85}$

In addition to the sparse use of Parque 3 de Febrero, municipal authorities were likewise perplexed by what appeared to them as the uncivilized behavior exhibited in the newly created public space. Shortly after its inauguration, a commission was formed to "establish rules that would regulate the activities of those that visit the park." Among the guidelines set forth in the resolution, it was prohibited to "utter threats or insults, or use insulting or indecent language, or carry out any act that tend to disrupt the peace." It was further stipulated that, "any individual that is inebriated or commits any disorderly or improper act or that does harm or damage can be removed from the premises of the park by the police." 86 Of repeated concern was the nature and extent of vandalism carried out in Parque 3 de Febrero. To the caretakers of the park, such behavior was a result of "rogues and vagrants who find delight in causing damage" and further noted that "the lack of respect is shameful." 87 Commenting on the destruction in the park, one park director observed:

83. MCBA, "Memoria de la Intendencia Municipal de Buenos Aires correspondiente a 1908" (Buenos Aires: G. Kraft, 1909), VI, 374-75.

84. MCBA, “Memoria 1909,” 391-92.

85. Onelli, Idiosincrasias de los pensionistas, 49.

86. MCBA, "Memoria del Vice Presidente de la Comisión Municipal al Concejo" (El Nacional, 1876), 149-50.

87. Quoted in Berjman, Plazas y parques de Buenos Aires, 78. 
The destruction of plants and trees in the plazas and paseos by ill-meaning people is frequent and I can not explain why there are people who find joy in tearing out and destroying that which costs money and labor and which is well cared for with the only purpose of beautifying the city and providing a place of recreation for the public. ${ }^{88}$

In the zoo, similarly destructive behaviors showed the lack of "culture" of the patrons who at times "entertain themselves by throwing matches at the monkeys" and other animals. It was not uncommon therefore that "the death of the animals often followed a holiday" when large crowds passed through the zoo. ${ }^{89}$

Despite the signage and the "severe penalties posted in the park" caretakers complained that "nothing is enforced" and that it was "rare" to see police action. ${ }^{90}$ As such, park directors and city officials called upon the police to "monitor the parks" with increased vigilance and to establish a "permanent presence so as to instill respect." 91 For many porteños, an increased police presence would be the only way possible to "conserve order in our public spaces." 92 In contrast, others believed that the "other minor infractions will only be avoided when the people, in general, understand that the park belongs to them and was made for their comfort, and thereby they become the guardians of their property, as is done in other countries, where they respect their public spaces." 93

88. MCBA, "Memoria del Presidente de la Comisión Municipal al Concejo correspondiente al ejercicio de 1878" (Buenos Aires, 1879), 138.

89. MCBA, "Memoria 1889,” 194.

90. MCBA, "Memoria 1878," 138.

91. Quoted in Berjman, Plazas y parques de Buenos Aires, 78.

92. MCBA, "Memoria presentada al H. Concejo Deliberante por el Intendente Municipal Dr. Francisco Alcobendas; año 1896” (Buenos Aires, 1897), 39.

93. MCBA, "Memoria 1876," 181. 


\section{Conclusions}

As originally conceived by Sarmiento and subsequent members of Argentina's governing elite, Parque 3 de Febrero and the Jardín Zoologico were meant to transform the city and its people. In matters of hygiene, the park and the zoo were intended to be metaphorical lungs that would provide pure air to a population plagued by pulmonary disease and overcrowded living conditions. Furthermore the spaces were designed to improve public health by offering recreational opportunities to the city's inhabitants regardless of social status. Despite these lofty ambitions, the Parque 3 de Febrero and the Jardín Zoologico - located in Palermo far from the working class neighborhoods of Buenos Aires - primarily benefited affluent porteños who in essence appropriated the public spaces as an extension of their private lives and activities. ${ }^{94}$ Critical of such actions, the press ridiculed the well-to-do who, instead of physical exercise, preferred to "exercise a wandering glance, being sure to admire the horses and carriages" of their social counterparts who visited the park. ${ }^{95}$ Thus, similar to the parks in Paris and London, the Parque 3 de Febrero became a "theater of regulated behaviors" monopolized by the porteño elite.

Beyond hygiene and health, proponents of the park and the zoo argued that the spaces were part of an overall effort to erase the colonial facade of the city and thus portray a sense of modernity in the nation's capital. Moreover, and equally relevant, the political protagonists of the late nineteenth and early twentieth centuries were certain that the Parque 3 de Febrero and the adjacent zoo would help civilize the masses and foster a collective Argentine identity. As such, the spatial and ideological constructs associated with the park and the zoo became metaphorical representations of the notions of order and progress that permeated the elite discourse of the period. In this regards, the reclamation of Rosas' land, the presence of public art and architectural relics, and the use of French elements of design in the construction and landscaping of the two spaces attested to the cultural sophistication of the nascent republic. However, much to their

94. Needell, "Rio de Janeiro and Buenos Aires," 535.

95. El Nacional, October 12, 1882. 
chagrin, state and municipal officials eventually conceded that the physical transformation of the city far out paced the desired behavioral changes in the populace. Instead of eradicating the perceived backwardness of the working class, the park and the zoo became contested spaces in which the relatively harmless yet disorderly conduct of the gente comun challenged the status quo of society. In this regards, Sarmiento, like other prominent figures of the Generation of 37 and the Generation of 80 , recognized that the park in many ways had fallen short of what was originally envisioned. Cognizant of this perceived failure, Sarmiento lamented to the porteño press that, "Palermo is still very far away."

Inherent in Sarmiento's observation was the realization that the complex interactions in the park and the zoo in Palermo were in fact representative of the ideological and socioeconomic differences within porteño society as a whole. The financial crisis of 1890 followed by subsequent years of labor unrest exposed the overall deficiencies of liberalism and challenged the "official rhetoric of progress" espoused by the ruling oligarchy. ${ }^{97}$ With broad support from the immigrant neighborhoods, Radicals and Socialists encouraged political reform through popular democracy. In matters of public space and hygiene, marginalized porteños were no longer content waiting for the time when the "elite's business and cultural interests happened to coincide with the residential area of the city's poorest." 98 Instead, the working class called for increased park space and improved living conditions in the city's central and southern neighborhoods. Though improvements were made, change was slow and the demands were only fully realized with the populist politics of Juan Perón in the mid-twentieth century.

96. El Nacional, 1883 cited in Gorelik, La grilla y el parque, 52.

97. Salvatore, "The Normalization of Economic Life," 24.

98. Needell, "Rio de Janeiro and Buenos Aires," 538. 
Table 3.1

Population of Buenos Aires, 1869-1914 ${ }^{99}$

$\begin{array}{rr}\text { Year } & \text { Population } \\ 1869 & 187,346 \\ 1875 & 269,121 \\ 1880 & 337,617 \\ 1887 & 433,375 \\ 1895 & 663,854 \\ 1904 & 950,891 \\ 1909 & 1,231,698 \\ 1914 & 1,576,597\end{array}$

99. Baily, "Patterns and Immigrant Assimilation," 36; Guy Bourdé, "La condition ouvière à Buenos Aires à la fin du XIXe et au début du XXe siècle," Le Mouvement Social 84 (JulySeptember 1973): 3-33. 
Image 3.1

Maps of Buenos Aires Corresponding to 1870 and 1890

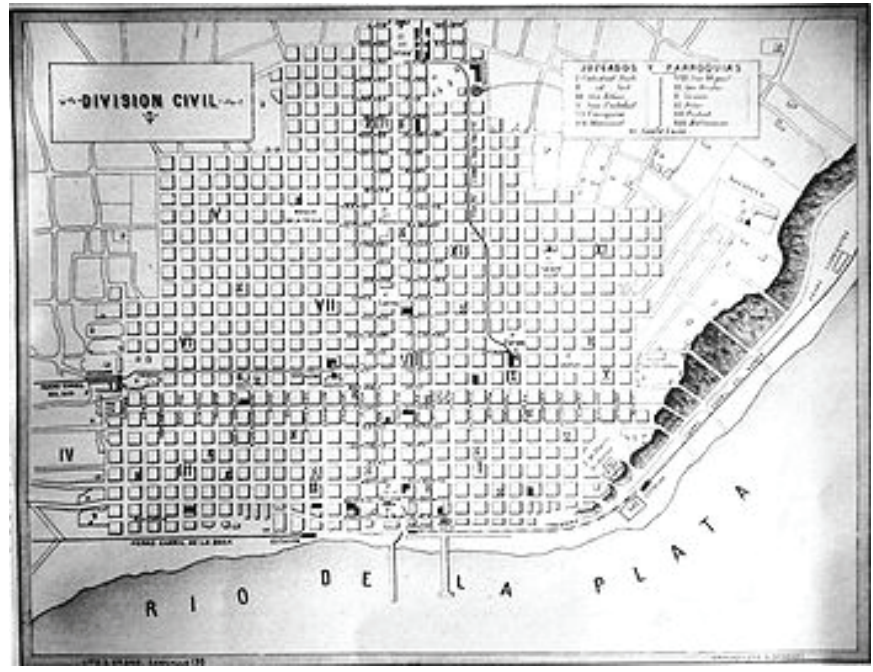

Buenos Aires City Map 1870

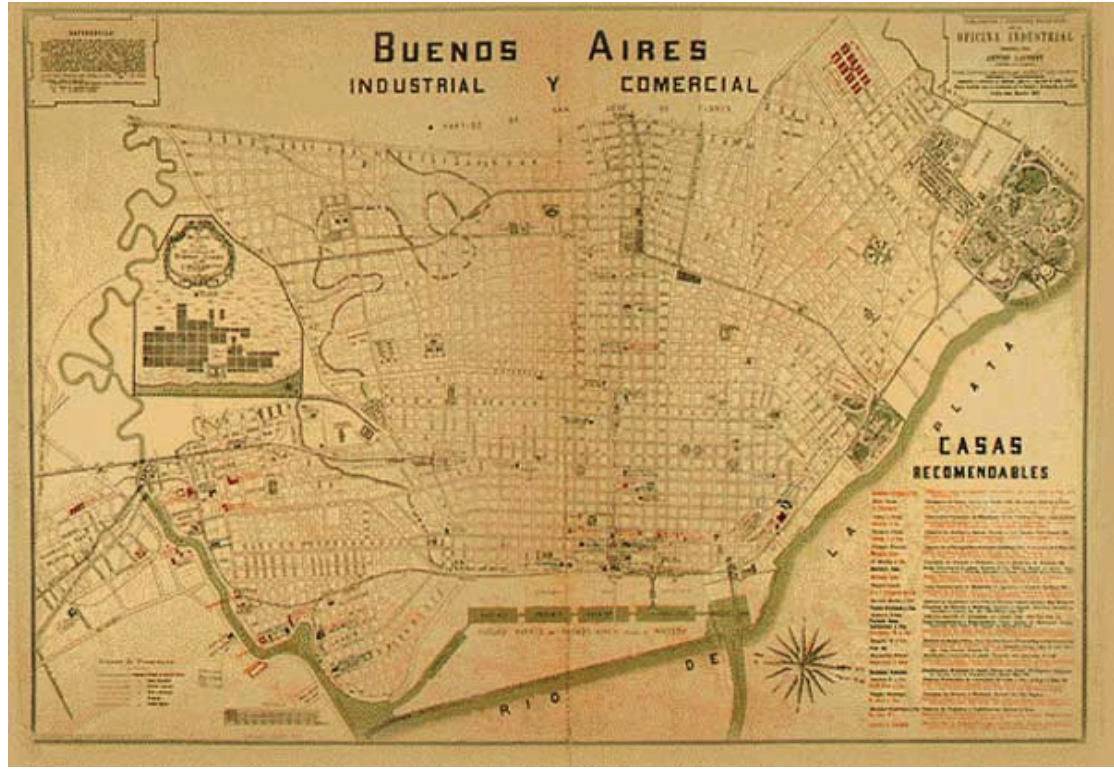

Buenos Aires City Map 1890 


\section{CHAPTER 4}

Guardians of the Public Health and the Private Domain

Introduction

An oil on canvas by the artist, Juan Manuel Blanes, vividly portrays a tragic scene from the great epidemic of 1871. Apparently having succumbed to yellow fever, the lifeless body of a young mother lies on the floor just inside the threshold of an open door. An infant, not yet old enough to walk, attempts to nurse from her breast. Perhaps aroused by the cries of the baby, a small crowd has gathered to witness the somber moment. Two men, their attire suggesting a degree of influence, stand at the door. One reverently clasps his hands together and bows his head while the other respectfully removes his hat as he enters. Peering into the room from the street, a group of onlookers contort the upper portions of their bodies to view the unfolding events. A servant boy holds the door, his gaze fixed not on the woman but on the men next to him, and anxiously awaits their next instructions.

Blanes' moving representation was allegedly based on a letter dated March 17,1871 from police commissioner, Lisandro Suárez, to the Chief of Police, Enrique O'Gorman. In the letter, Suárez informed the Chief that a woman by the name of Ana Britiani, residing on the street Balcarce number 384, was found dead during the early hours of the morning. Providing the details of the discovery, Suárez notes that on a routine patrol of the neighborhood, the night watchmen noticed the open door and proceeded to check on the occupants. Entering the home, the watchman discovered Britiani and the child. Neighbors of the family later indicated to the 
commissioner that the husband was also sick and was being cared for somewhere in the workingclass neighborhood of Boca de Riachuelo. The commissioner concluded his report noting that the baby had been placed under the care of the proper authorities and that the few possessions inside the home "though of little value" would be held until claimed by the husband. ${ }^{1}$

The letter and the painting it inspired offer a fascinating glimpse into state-society relations. Of concern to the commissioner is the need to inform his superior that the unfortunate event was resolved with efficiency and exactness. As such, Britiani's death is a circumstantial feature in the narrative while the focus of Suárez is aimed at the efficiency with which he and others carried out their duties as public officials. Similarly, in the painting, Britiani's body is cast in the shadows and the more pronounced figures are those at the door. Interestingly, the two men are not the night watchman and police commissioner as might be presumed. Instead, taking some degree of artistic liberty, Blanes includes two of the city's most respected medical authorities, doctors who lost their lives during the epidemic, José Roque Pérez and Manuel G. Argerich, as the primary witnesses of the tragedy. The presence of these individuals is a simple tribute to the two physicians and many others of the profession who lost their lives during the epidemic.

Moreover, their inclusion hints at the increased status and respect that the profession had come to enjoy in society. Together, the written account and visual representation foreshadow the close association that would develop between civil authorities and medical practitioners along with the increased influence that these two groups would exert upon the private lives of the people. Under the banner of hygiene, municipal and state authorities infiltrated the private domains of porteños during the late nineteenth and early twentieth centuries to cleanse the city of diseases, perceived and real, that threatened the established order and hindered modernization.

Reference to the private domain as a topic of scholarly interest calls immediate attention to the writings of Philippe Ariès. Recognized primarily for his discussion on the life cycle and its developmental stages, Ariès identified the distinction between public and domestic spaces and the

\section{Ruiz Moreno, La peste histórica, 331.}


influence that each exerted on the family in western societies. Central to his argument is the gradual transition in attitudes towards children from the Middle Ages to the eighteenth century that resulted in an increased awareness of parental responsibility in the formation of proper adults. As such, the family became an instrument of progress in the civilizing and socialization process. $^{2}$

More compelling perhaps than the theory itself is the paradox that periodically surfaces in Ariès' work. Influenced by the Annales school of thought and in particular the ideas of Lucien Febvre, Ariès acknowledged that the family was both a medium of progress and an obstacle to change. Febvre believed that new ideas associated with modernity challenged "old and often binding intellectual structures" and as such the problem in studying the culture of the common person was not the "intellectual's visionary leap toward the future, but the ordinary individual's tenacious hold on the wisdom of the past." In this regard, Ariès concluded that the family was a "drag on modernization." Moreover, the family and the private sphere acted as a "repository of the waning cultural heritage" and was likewise a refuge for the values and traditions that forwardthinking sectors of society wished to alter or discard. ${ }^{3}$ In Latin America, the notion that the private domain was a vestige of archaic customs and practices was nowhere more evident than in the discourse and tension that surrounded issues of hygiene. With this realization, the governing elite of the region acknowledged that the unsanitary and antiquated practices that were common within the domestic spaces of their respective nations would eventually jeopardize any and all efforts of progress and modernization.

2. Ariès and Duby, A History of Private Life: Revelations of the Medieval World; Philippe Ariès, Centuries of Childhood: A Social History of Family Life (New York: Knopf, 1962).

3. Patrick H. Hutton, “The History of Mentalities: The New Map of Cultural History," History and Theory 20, no. 3 (October 1981): 244-46; Philippe Ariès, ed., "Western Attitudes Towards Death from the Middle Ages to the Present," trans. Patricia M. Ranum (Baltimore: The Johns Hopkins University Press, 1974). 
The creation of the Dirección General de la Asistencia Pública in 1883 in Buenos Aires and its subsequent authority over the private lives of porteños offers a unique glimpse into the profound social and political changes that defined fin de siècle Argentina. Shaped by the positive discourse of the period and likewise influenced by some of Argentina's most notable hygienists, the Asistencia Pública was charged with administering health and social service institutions in Buenos Aires and with improving the overall hygiene and sanitary conditions of the capital. In its efforts to prevent disease and care for the sick, the Asistencia Pública found its way into the homes of porteños through general health inspections, disinfections, medical home visits, and vaccinations. Of these, the initiative to enforce a compulsory smallpox vaccination ordinance adopted in 1886 proved to be the most comprehensive and perhaps the most resisted. At times, the resistance was overtly hostile and thereby required police assistance or intervention. However, in most cases, porteños simply provided false addresses to the civil registry following the birth of a child or changed residences in order to avoid the vaccination teams sent into the city's tenements by the Asistencia Pública. As such, this chapter adopts the theoretical premises advanced by James C. Scott and argues that the elusiveness of the population was a subtle yet effective form of resistance to the state's efforts to dominate the private sphere under the banner of hygiene. ${ }^{4}$

The Higienistas and the Dirección General de la Asistencia Pública

The hygienist movement in Latin America emerged in the mid-nineteenth century and was a unique combination of local ideologies blended with foreign practices. ${ }^{5}$ From Mexico City

4. James C. Scott, Weapons of the Weak: Everyday Forms of Peasant Resistance (New Haven: Yale University Press, 1985).

\section{Abel, Health, Hygiene and Sanitation; Margaret Horn, Health, Society and Culture in Latin} America (Durham, N.C.: Duke University Press, 1994). See also the historiographical essays in Marcos Cueto, Salud, cultura y sociedad en América Latina; Diego Armus, Entre médicos y curanderos; Diego Armus, Disease in the History of Modern Latin America. 
to Buenos Aires, hygienist influenced policies transformed the appearance of the region's metropolitan centers and further initiated a "battery of laws, ordinances and institutions intended to [improve] the sanitary condition" of the cities and their inhabitants and thereby accelerate the "process of modernization and progress" befitting of a developing nation. ${ }^{6}$ Under the guise of hygiene, the governing elite constructed new promenades, boulevards, plazas and other public spaces to provide "reservoirs of pure air and greater health to the city." ${ }^{7}$ Moreover, in addition to green spaces, public works projects such as running water, trash removal, the construction of new cemeteries, and engineered sewer and drainage systems were portrayed as "indispensable in improving the sanitary conditions of the city and in combating diseases that decimated the population." 8

Beyond the physical aspects of the urban centers, hygienists were likewise concerned about endemic and epidemic diseases that deterred European investment and immigration, reduced the supply of domestic labor, or that had other economic, political, and social

6. Adriana Alvarez, "Resignificando los conceptos de la higiene."

7. Florencia Quesada, "Transformatión urbana y cambio socio-espacial: Ciudad de Guatemala y San José de Costa Rica, 1880-1930," paper presented at, Latin American Studies Association XXII International Congress (Miami, FL, 2000), 10 See also Needell, "Rio de Janeiro and Buenos Aires"; Mauricio Tenorio Trillo, "1910 Mexico City: Space and Nation in the City of the Centenario," Journal of Latin American Studies 28, no. 1 (February 1996): 75-104.

8. Ramona Isabela Pérez Bertruy, "La modernización de paseos y jardines públicos en la Ciudad de Mexico durante el Profiriato," paper presented at, Latin American Studies Association XXII International Congress (Miami, FL, 2000), 1; Emily Wakild, "Naturalizing Modernity: Urban Parks, Public Gardens and Drainage Projects in Porfirian Mexico City," Estudios Mexicanos 23, no. 1 (Winter 2007): 101-23; Claudia Agostoni, "Sanitation and Public Works in Late Nineteenth Century Mexico," Quipu: Revista Latinoamericana de Historia de las Ciencias y la Tecnologia 12, no. 2 (1999): 187-201. 
implications. For example, in Rio de Janeiro, physicians and public health officials preoccupied with increasing bouts of yellow fever created the Junta Central de Higiene Pública in 1850, the first general board of health of its kind in Brazil. Members of the Junta postulated the idea that the disease was somehow connected to the slave trade and thus utilized notions of the disease in their discourse to pressure the Imperial government to abolish the commercial trafficking of African slaves. ${ }^{9}$ Likewise, poor public health in Chile led to the organization of the Junta General de Salubridad in 1887 by President José Manuel Balmaceda. Of particular interest to the Junta was the repeated occurrences of smallpox and cholera and the high rate of infant mortality in working class neighborhoods. ${ }^{10}$ Elsewhere, and with similar agendas, physicians, scientists, and the governing elite confronted the diseases that devastated local populations and threatened progress. In Colombia, Peru, and Brazil hygienists directed their attention to malaria and other tropical disorders whereas in Mexico and Ecuador the socioeconomic implications of cholera were of concern. ${ }^{11}$ Finally, it is necessary to understand that the hygienist movement in Latin

9. Sidney Chalhoub, "The Politics of Disease Control: Yellow Fever and Race in Nineteenth Century Rio de Janeiro,” Journal of Latin American Studies 25, no. 3 (October 1993): 444-51.

10. Carl T. Murdock, "Physicians, the State and Public Health in Chile, 1881-1891," Journal of Latin American Studies 27, no. 3 (October 1995): 551-67.

11. Robin L. Anderson, "Public Health and Public Healthiness, São Paulo, Brazil, 1879-1893," Journal of the History of Medicine and Allied Sciences 41, no. 3 (1986): 293-307; Julyan G. Peard, "Tropical Disorders and the Forging of a Brazilian Medical Identity," Hispanic American Historical Review 77, no. 1 (February 1997): 1-44; Nancy Leys Stepan, “"The Only Serious Terror in These Regions': Malaria Control in the Brazilian Amazon," in Disease in the History of Modern Latin America: From Malaria to AIDS, ed. Diego Armus (Durham, NC: Duke University Press, 2003), 25-50; Elsy Bonilla, Salud y desarollo: Aspectos socoeconómicos de la malaria en Colombia (Bogotá: Universidad de los Andes, 1991); Marcos Cueto, "Identidad regional y malaria en el Perú del siglo XX," in El regreso de las epidemias: Salud y sociedad en el Perú del 
America was intimately intertwined with the social issues that characterized the different countries of the region. As such, discussions concerning education, poverty, the family, race, gender, and sexuality were influenced by the developing notions of hygiene. ${ }^{12}$

The hygienist movement in Argentina followed a similar trajectory as that of the rest of Latin America and was a key element in the state-formation process of the late nineteenth and early twentieth centuries. Emilio Coni, one of the country's most renowned hygienists summarized the role of hygiene noting that, "From the beginning of my studies, I came to realize

siglo XX, ed. Marcos Cueto (Lima: IEP, 1997), 127-72; Ronn F. Pineo, "Misery and Death in the Pearl of the Pacific: Health Care in Guayaquil, Ecuador, 1870-1925," Hispanic American Historical Review 70, no. 4 (November 1990): 609-37; Lilia V. Oliver, "El Cólera y los Barrios de Guadalajara," in Salud, Cultura y Sociedad en América Latina, ed. Marcos Cueto (Lima: IEP, 1996), 87-110.

12. Patience A. Schell, "Nationalizing Children Through Schools and Hygiene: Porfirian and Revolutionary Mexico City,” The Americas 60, no. 4 (April 2004): 559-87; Claudia Agostoni, "Discurso médico, cultura higiene y la mujer en la ciudad de México al cambio del siglo (XIXXX)," Mexican Studies/Estudios Mexicanos 18, no. 1 (Winter 2002): 1-22; Sonia Roncador, “O demônio familiar: Lavadeiras, amas-de-leite e criadas na narrativa de Júlia Lopes de Almeida,” Luso-Brazilian Review 44, no. 1 (2007): 91-119; Bliss, "Science of Redemption"; Ann Zulawski, "Hygiene and 'The Indian Problem': Ethnicity and Medicine in Bolivia, 1910-1920," Latin American Research Review 35, no. 2 (2000): 107-29; Nancy Leys Stepan, “The Hour of Eugenics": Race, Gender, and Nation in Latin America (Ithaca, NY: Cornell University Press, 1991); Nancy Appelbaum and Anne S. Macpherson, eds., Race and Nation in Modern Latin America (Chapel Hill, NC: University of North Carolina Press, 2003); Benigno Trigo, Subjects of Crisis: Race and Gender as Disease in Latin America (Hanover, NH: University Press of New England, 2000); Eileen J. Suárez Findlay, Imposing Decency: The Politics of Sexuality and Race in Puerto Rico, 1870-1920 (Durham, NC: Duke University Press, 1999). 
that the great promise of medicine was to be found in public and social hygiene and that the real mission of the physician was, above all, to prevent disease."13 Evident in Coni's observation are three fundamental ideas that defined the hygienist movement in Argentina. Foremost, medical practitioners were as much or more concerned about the prevention of disease as they were about its treatment. Second, in addition to preventing disease, hygienists identified themselves as the guardians of public health monitoring the sanitary condition of the urban landscape. Finally, and of particular importance, Coni and others believed that it was their duty to fight against the backwardness of the population and the ills that plagued society through policies of social hygiene. In matters of disease prevention, Argentine hygienists focused their attention on protecting the cities and their inhabitants from communicable diseases such as cholera, yellow fever, smallpox, tuberculosis, and tetanus. ${ }^{14}$ Social issues that were included in the hygienist discourse included reproduction and sexuality, madness, and criminality. ${ }^{15}$

13. Emilio R. Coni, Memorias de un médico higienista: Contribución a la historia de la higiene pública y social Argentina (Buenos Aires: Talleres Graficos A. Flaiban, 1918), XII.

14. Olga N. Bordi, Cólera e inmigración, 1880-1900 (Buenos Aires: Editor Leviatán, 1992); Héctor Recalde, Las epidemias de cólera (1856-1895): Salud y sociedad en la Argentina oligárquica (Buenos Aires: Corregidor, 1993); Diego Armus, "Consenso, conflicto y liderazgo"; Diego Armus, Ciudad impura; Reber, "Misery, Pain, and Death"; Reber, "Blood, Coughs, and Fever."

15. Donna J. Guy, Sex and Danger in Buenos Aires: Prostitution, Family, and Nation in Argentina (Lincoln: University of Nebraska Press, 1991); Salessi, Médicos maleantes y maricas; Karen Mead, "Gendering the Obstacles to Progress in Positivist Argentina, 1880-1920," Hispanic American Historical Review 77, no. 4 (1997): 645-75; Karen Mead, "Beneficent Maternalism: Argentine Motherhood in Comparative Perspective, 1880-1920," Journal of Women's History 12, no. 3 (Autumn 2000): 120-45; Ruggiero, Modernity in the Flesh; Kristin Ruggiero, "Honor, Maternity, and the Disciplining of Women: Infanticide in Late Nineteenth- 
For their accomplishments in preventing disease, medical scientists, doctors, and hygienists began to be recognized in society as a professional elite and thus acquired a certain prestige unprecedented in previous years. According to Michel Foucault, this process of "medicalization" resulted not only from scientific discoveries that benefited medical procedures but also from the willingness of the masses to submit to the authority of the physician. ${ }^{16}$ One scholar referred to this process as,

the gradual disappearance of traditional, more or less fatalistic attitudes towards health and illness, and the extension of professional medical services to those social strata in which the professional medical practitioner had hitherto remained unknown. As the process of medicalization advanced, it became increasingly common to appeal to competent experts, to the medical professionals. This process was accompanied by a loss of independence on the part of the patient, and at the same time resulted in an increase in the power and status of the medical profession. ${ }^{17}$

Century Buenos Aires," Hispanic American Historical Review 72, no. 3 (1992): 353-73; Julia Rodriguez, Civilizing Argentina: Science, Medicine, and the Modern State (Chapel Hill: University of North Carolina Press, 2006); Andrew Lakoff, “The Simulation of Madness in Buenos Aires, 1903," Critical Inquiry 31, no. 4 (Summer 2005): 848-73; Gabriela Nouzeilles, “An Imaginary Plague in Turn-of-the-Century Buenos Aires: Hysteria, Discipline, and Languages of the Body," in Disease in the History of Modern Latin America: From Malaria to AIDS, ed. Diego Armus (Durham, NC: Duke University Press, 2003), 51-75.

16. Michel Foucault, The Birth of the Clinic: An Archaeology of Medical Perception (London: Tavistock, 1973); Michel Foucault, Discipline and Punish: The Birth of the Prison (New York: Pantheon, 1977).

17. Claudia Huerkamp, "The History of Smallpox Vaccination in Germany: A First Step in the Medicalization of the General Public," Journal of Contemporary History 20, no. 4 (October 
Not surprisingly, the newly acquired status of medical practitioners often led to subsequent political appointment to municipal commissions or national ministries.

In Buenos Aires during the mid-nineteenth century, matters pertaining to public health and hygiene fell under the jurisdiction of two separate government entities: the Consejo de Higiene Pública and the Comisión de Higiene. Established in 1852 by the government of the province of Buenos Aires, the Consejo de Higiene Pública was responsible for guarding the port against the threat of disease and directed the small cadre of sanitary police who carried out inspections. Furthermore, the Consejo assumed control over the sale of medicine and medical supplies and likewise oversaw the maintenance of the city's hospitals, pharmacies, cemeteries, and vaccination efforts. In 1857, in conjunction with the formal organization of the municipal government, the Comisión de Higiene was created and given charge over managing the parish hygiene commissions which in turn monitored the respective neighborhoods for signs of illness and disease. With the federalization of Buenos Aires in 1880, the Consejo de Higiene became the Departamento Nacional de Higiene and relinquished many of its responsibilities in the capital to the Comisión de Higiene. Over the next three years, physicians serving on the governing board of the municipal council and on the Comisión de Higiene recognized the inherent weakness of the organization and lobbied for the creation of stronger, more centralized institution to oversee all aspects of medicine and hygiene in the city. As such, on January 3, 1883, the Comision Municipal approved the creation of the Dirección de la Asistencia Pública de Buenos Aires and appointed Dr. José María Ramos Mejía as its first director.

As its director, Ramos Mejía lauded the Asistencia Pública as an "eminently practical institution empowered to protect the health of the Municipality."18 Based on this perception, Ramos Mejía argued that the Asistencia "should slowly extend its branches" and that its eventual

1985): 617 .

18. MCBA, "Memoria de la Intendencia Municipal de la Ciudad de Buenos Aires correspondiente a 1885, presentada al H. Concejo Deliberante" (Buenos Aires, 1886), 7. 
growth would be determined by the needs of society. ${ }^{19}$ Thus at its inception in 1880 , the Asistencia Pública assumed responsibility for the Administración de Vacunas, Hospital de San Roque (asylum for the insane), Hospicio de las Mercedes (shelter for the indigent), Casa de Aislamento (quarantine) and the Asistencia a Domicilio (home visits), the Hospital de Buenos Aires, and the Hospital de Hombres. By 1888, Ramos Mejía and his successor, José María Astigueta had increased the services of the Asistencia to include the oversight of wet nurses and prostitutes, vaccinations, ambulance services, transportation of cadavers, disinfections, inspections of private and public buildings, and other activities. ${ }^{20}$ As further evidence of the bureaucratic development of the department, within a decade Asistencia Pública grew from a handful of employees housed in a small office within the Hospital San Roque to 745 employees located in different offices throughout the city with a total payroll of $\$ 723,320$ per year. ${ }^{21}$

As the Asistencia grew and showed its strength in the public realm, it also increased its presence in the private domains of the city's inhabitants as health inspectors, disinfection teams, and medical practitioners increased their vigilance of the activities carried out in porteño homes. For administrative purposes, the city was divided into twenty geographical sections or territories and municipal hygiene commissions for each district replaced the antiquated parish commissions that had been in place since the organization of the municipality in 1857 . The hygiene commissions consisted of five vecinos or residents of the designated neighborhood who were responsible for reporting cases of infectious disease to the medical physician assigned to the section. Additionally, the vecinos were encouraged to monitor the unsanitary conditions of the conventillos and casas de inquilinato and report any sickness or unsanitary practice. On the basis of the information provided, the trained physician would visit the identified dwelling and provide the necessary medical attention. In this way, the Asistencia Pública utilized an "old and respected

19. MCBA, "Memoria 1887," 243; MCBA, "Memoria 1885," 7.

20. MCBA, "Memoria 1888," 40.

21. MCBA, "Memoria 1896," 71. 
vecino" to help "penetrate the homes, in which for some time the art of healing had been reserved by the neighborhood curandero or more likely by family remedies." ${ }^{22}$ For José María Astigueta, the second director of the Asistencia Pública, the practice was the ideal method of reaching porteños in their homes because it paired a "man of science" with a "well known vecino" and converted both into "agents of the public health." 23 At first carried out only in times of epidemics, medical practitioners and municipal authorities argued that increased domiciliary visits for reported cases of infectious disease would prove beneficial. More than a defense against disease, authorities viewed the practice as a way to "combat negligence, carelessness, and indolence ... the most common causes of misery and the reasons as to why the precepts of hygiene are violated." Moreover, home visits would necessarily "improve hygienic conditions realizing an incalculable benefit to the population." ${ }^{24}$ In 1884, a year after the creation of the Asistencia Publica and its vigilance over home visits, 7,266 individual home visits were carried out. Of the total number visited, 2,997 were women and 2,378 were children. ${ }^{25}$ In 1885 , of the total 5,553 home visits, $68 \%$ were for women and children.. ${ }^{26}$ Although in some years, home visits to men outnumbered those of women, the records indicate that generally, women and children were the principal targets of medical home visits.

22. Adriana Alvarez, "Resignificando los Conceptos de la Higiene."

23. MCBA, "Memoria de la Intendencia Municipal de la Capital de la República correspondiente a 1886, presentada al Honorable Concejo Deliberante" (Buenos Aires: M. Biedma, 1887), 388.

24. MCBA, "Memoria 1887," 388.

25. MCBA, "Memoria de la Intendencia Municipal de la Ciudad de Buenos Aires correspondiente a 1884, presentada al Honorable Concejo Deliberante" (Buenos Aires, 1885), 71-73.

26. MCBA, "Memoria 1885," 29. 
In addition to medical home visits by physicians, the Asistencia Pública increased its presence in the private domain through a corps of health inspectors who monitored the various sections of the city. The legal framework establishing the group of health inspectors was found in an ordinance adopted by the Comisión Municipal in 1875. Under the general direction of the municipal Comisión de Higiene, health inspectors worked with parish hygiene commissions to monitor the sanitary condition of the city's neighborhoods. Specifically, the ordinance stipulated that the inspectors were to observe the homes of porteños for any unhealthy practice and safeguard the city by identifying unreported cases of infectious disease. Additionally, the inspectors were to enforce any and all ordinances pertaining to hygiene passed by the municipal council. Despite the ordinance, inspections were rare and often uncoordinated. In his annual report to the Comisión Municipal in 1881, the intendente, Torcuato de Alvear, acknowledged the haphazard efforts of the inspectors and reiterated the urgency of frequent and thorough inspections. He further assured the governing board that team would be more vigilant in their inspections especially within the conventillos and casas de inquilinato, or working-class apartments which were considered to be the source of the many diseases that plagued the city. ${ }^{27}$ The following year, noting little improvement, Alvear expressed with frustration,

Our municipality ... is negligent in carrying out the precautions of hygiene. This negligence in some and ignorance in others is being felt by the population through the manifestation of malignant diseases that require us to be more diligent in enforcing the ordinances we have authored in our role as guardians of the public health. ${ }^{28}$

To be certain that such negligence did not continue, the Asistencia Pública, upon its creation in 1883, was given administrative oversight of the team of twenty-two inspectors and was directed

27. MCBA, "Memoria del Presidente de la Comisión Municipal al Concejo correspondiente al ejercicio de 1881” (Buenos Aires: Imprenta M. Biedma, 1882), 329.

28. MCBA, "Memoria 1883," 16-17. 
to enforce the edicts of the municipal council and improve the hygienic conditions of the city. By 1889, the Asistencia Pública had added thirteen new inspectors to its corps with each inspector overseeing a territory of forty to sixty city blocks. ${ }^{29}$

As can be expected, the increased number of inspections and the ever-growing presence of the municipal inspectors in the city's neighborhoods often produced deep feelings of animosity. Surprise inspections during the late hours of the night, the separation of families through quarantines, and forced evacuations were seen by many as an attack on the privacy of the porteño family. ${ }^{30}$ Disdain for the inspectors also stemmed from the fact that inspection teams were at times summoned to converge upon a home only to find that the denouncement was unwarranted and that the accusation of an unsanitary dwelling was merely an act of spite by local neighbors. ${ }^{31}$ Recognizing such feelings, health inspectors frequently requested the assistance of the local police to counter potential resistance and to help enforce the ordinances that were "inspired by experience" and which were meant to govern the "health and unhealthiness of cities and their populations." 32

Though authorized to carry out drastic measures when necessary, most inspections resulted in fines that were levied against those that violated the proscribed ordinances. However, inspectors lacked the authority to actually impose the collection of fines. ${ }^{33}$ If a fine was not rendered to the authority at the time the citation was issued, the matter was turned over to judicial authorities "with all of the delays and inconveniences that such presents." 34 According to one

29. MCBA, "Memoria 1890-1892," 358.

30. MCBA, "Memoria 1884," 139-40.

31. MCBA, “Memoria 1890-1892,” 62.

32. MCBA, "Memoria 1881," 323,329-330.

33. The collection of taxes or fines seems to have been problematic for municipal authorities as early as the 1820s. See Szuchman, "Constructing the City," 203.

34. MCBA, "Memoria 1890-1892," 358. 
critic, the inefficiency of the judicial process made it possible for those who had violated an ordinance to avoid having to pay the fine and thereby "strip the Inspection of its authority and prestige." ${ }^{, 35}$ As result, when inspectors again visited a home and demanded payment, the accused no longer resided in the dwelling or had forgotten the fine thus producing a series of "protests and accusations ... against the employees of such a hated commission." 36 Table 4.1 highlights the disparity between the amount of fines rendered and the total amount collected.

\section{Table 4.1}

Fines rendered by Municipal Inspectors of Hygiene, 1889-1892

After nearly two decades, little had changed in the ability to collect fines from specific infractions. In 1909 there were 29,670 fines rendered totaling \$780,764 with just over $\$ 329,000$ being collected. ${ }^{37}$

Perhaps equally hated by porteños were the disinfection teams employed by the Asistencia Pública and which likewise invaded the private sphere of the city's inhabitants. Established in 1888, the Cuerpo de Disinfectadores acted in response to cases of disease reported by either the municipal inspectors and neighborhood doctors or if requested by residents of the city. The general procedure for the disinfections followed strict guidelines. Disinfection teams arrived wearing a special suit provided by the administration. The suit completely covered the clothing of the employee and the head was to be covered by a cloth hat. Hair and beards were to be trimmed short. Prior to entering the home, the team disinfected the soles of their boots in a bichloride mercury solution. Once in the home, the team removed any contaminated clothing, bedding, and household items that could be placed in a vapor humidifying stove to be cleansed.

35. MCBA, "Memoria presentada por el Intendente Municipal Dr. Federico Pinedo; años 1893 y 1894 (enero a julio)" (Buenos Aires, 1895), 711.

36. MCBA, "Memoria 1890-1892," 359.

37. MCBA, "Memoria 1909," 358. 
Children's toys were destroyed. Delicate items such as paintings were rubbed vigorously with bread crumbs and then wiped with a solution of carbolic acid. Rugs and tapestries along with items that would not fit or would be damaged in the stoves were instead scrubbed with the same bichloride mercury solution. The furniture, walls, and ceilings were likewise scrubbed with the bichloride solution beginning first with the floor, "so when the germs detach from the furniture, walls, and ceiling they fall onto the floor wet from the disinfectant and thereby do not disseminate." To complete the disinfection, the rooms were coated with sulphuric acid powder and locked for 24 hours. ${ }^{38}$ In 1889, the team disinfected 1,458 dwellings, by 1895 the number of homes disinfected increased to 4,542, and by 1905 disinfection teams were deployed to disinfect 7,017 residences. $^{39}$

\section{Smallpox and the Conventillo}

The campaign to eradicate smallpox in Buenos Aires offers a unique case in analyzing the increased role of the Asistencia Pública and the invasion of the state into the private lives of porteños. Smallpox was a frequent visitor to the shores of the Río de la Plata and made its appearance in Buenos Aires at least once a year. ${ }^{40}$ When the mortality rates were low-as was

38. MCBA, “Memoria 1893-1894,” 108-10.

39. MCBA, "Memoria de la Intendencia Municipal de la Ciudad de Buenos Aires correspondiente a 1889, presentada al H. Concejo Deliberante por el Intendente Seeber" (Buenos Aires, 1891), 129; MCBA, "Memoria Presentada al Concejo Deliberante por el Intendente Municipal Señor Emilio V. Bunge; Año 1895” (Buenos Aires, 1896), 60; MCBA, "Memoria de la Intendencia Municipal; año 1905” (Buenos Aires, 1906), 75.

40. Lucio Melendez, La viruela en la campaña: Cuasas de su propagación y de la excesiva mortalidad, pamphlet (Buenos Aires: Poder Ejecutivo del Consejo Municipal, 1878); José Penna and José María Ramos Mejía, La viruela en la América del Sud y principalmente en la Républica Argentina: historia, estadistica, clinica, y profilaxia (Buenos Aires: F. Lajouane, 1885); Pedro Mallo and José Antonio Pillado, Páginas de la historia de la medicina en el Río de la Plata 
the case in 1878 and again in 1881, when fewer than a dozen people per year died from the disease - smallpox generated very little excitement among the city's residents. However, smallpox in Argentina's principal city was anything but benign and periodically produced high death rates. Records indicate that in 1871, coinciding with the scourge of yellow fever that occurred that same year, a smallpox epidemic caused 1,656 deaths. Subsequently, in the ten year period between 1882 and 1892, repeated outbreaks produced nearly 8,000 casualties with the single highest rate of mortality occurring in 1890 when the disease claimed 2,198 victims. ${ }^{41}$ On more than one occasion, Ramos Mejía observed that the inhabitants of the city feared yellow fever and cholera more than they did smallpox and diphtheria notwithstanding the later two accounted for far more deaths. ${ }^{42}$

Of particular concern to hygienists and municipal officials was the frequency and severity of smallpox within city's tenement houses or conventillos. In his study on smallpox and the working-class of Buenos Aires, Dr. Guillermo Rawson, who taught the first classes on public hygiene at the medical school at the University of Buenos Aires, calculated that one-half or more of the casualties associated with the disease came from the conventillos. As validation of this claim, Rawson pointed to the 1883 epidemic of smallpox in which $66 \%$ of the 1,510 deaths were porteños living in the tenements. ${ }^{43}$ After studying these sobering figures, Rawson observed:

It is necessary, above all else, to clarify for the public memory this often forgotten fact: it is not only the hapless residents of the conventillos that pay the price of health and life for such disagreeable conditions, for it is these unhealthy dwellings that become the

(Buenos Aires: Imprenta Industrial, 1897); Fernando Alvarez, La viruela y la vacuna en la República Argentina (Buenos Aires: Caras y Caretas, 1916).

41. Besio Moreno, "Historia de las epidemias de Buenos Aires," 173.

42. MCBA, “Memoria 1883," 121.

43. MCBA, "Memoria 1883," 289. 
epicenters that cultivate and diffuse all of the deadly emanations that spread to even the highest levels of the population. ${ }^{44}$

For Rawson and other hygienists, the conventillos were a figurative powder keg that could be ignited with even the "smallest threat of a disease." 45

The conventillos first appeared in the mid-nineteenth century as well-to-do porteños migrated from the city center to Palermo, Belgrano and other more affluent neighborhoods north and west of the city. With simple modifications, the narrow yet deep colonial-style building with two to three interior patios proved to be a source of inexpensive housing for newly arrived immigrants whose meager daily earnings required that they live in close proximity to their places of employment. In 1880, municipal inspectors identified 1,770 conventillos with a total of 24,023 rooms housing 51,915 inhabitants. A decade later the number of tenements had increased to 2,249 with a total of 37,063 rooms shared by 94,723 individuals. ${ }^{46}$ By 1904 , an estimated $14 \%$ of the population of Buenos Aires lived in the tenements with a average density of 3.1 tenants per room. One municipal census determined that nearly three-fourths of those that resided in the conventillos were foreign born. ${ }^{47}$

44. MCBA, "Memoria 1893-1894,” 367-68.

45. MCBA, "Memoria del Presidente de la Comisión Municipal al Concejo correspondiente al ejercicio 1880; febrero de 1881” (Buenos Aires, 1881), 124.

46. MCBA, "Memoria 1890-1892,” 361-67.

47. Francis Korn and Lidia de la Torre, "La vivienda en Buenos Aires 1887-1914,” Desarollo Económico 25, no. 98 (Julio-Septiembre 1985): 251; Scobie, "Buenos Aires as a CommercialBureaucratic City," 1045 Scobie argues that if one accounts for the children born in Argentina to immigrant parents, the percentage of foreigners residing in the conventillos is probably closer to $90-95 \%$. 
Simple in design, the conventillos were built around a central corridor that ran from the street entrance to the rear of the building. This interior patio was the hub of conventillo activity and was used to cook meals; wash, iron and sew clothing; repair tools and other common activities. Small rooms measuring no more than twelve feet by twelve flanked each side of the corridor and were rented to groups of four to five single men or families. Each room had its own entrance and at times a small window that allowed natural light into the space during daylight hours. A single latrine might have been used by as many as fifty or more renters. In one recorded case, a home that was originally built to house a family of twenty-five (consisting of family members and servants) was subdivided to accommodate 340 persons. ${ }^{48}$ Following a visit to one conventillo, a municipal authority described the "narrow, humid rooms" in which it was "difficult for the air to circulate." He further commented that he was not surprised that the conventillos threatened the public hygiene and chided the owners and landlords who earned lucrative profits from such dwellings. ${ }^{49}$

Image 4.1

Interior Patio of a Conventillo in Buenos Aires, Early Twentieth Century

The municipal Comisión de Higiene and subsequently the Asistencia Pública vigilantly monitored the tenements and lobbied for the adoption of ordinances intended to address the "ignorance that led to the abandonment and neglect of all standards of cleanliness" and by doing so hoped to "reduce the incalculable danger" that the conventillos posed to the city. ${ }^{50}$ In 1871 and again twelve years later, when smallpox epidemics plagued Buenos Aires, the municipal government authorized the forced evacuation of conventillos in which the disease was most prevalent. As a result, in 1883, ninety-seven tenements were evacuated and boarded up. ${ }^{51}$ For the

48. Scobie, "Buenos Aires as a Commercial-Bureaucratic City," 1045-46.

49. MCBA, "Memoria 1882," 221.

50. MCBA, "Memoria 1887," 306-9.

51. MCBA, "Memoria 1883," 402. 
municipal authorities, such ordinances were intended to limit the severity of the disease that regularly, "killed and destroyed the inhabitants of the urban center." 52

The persistent nature and intensity of smallpox in the conventillos and throughout the city in general perplexed the medical profession and governing elite of Buenos Aires. Immunization against the virus was available in Latin America shortly after Edward Jenner's discovery of the vaccine in 1796 and an extensive vaccination campaign sponsored by the Spanish Crown was initiated throughout the region. In Puerto Rico for example, officials administered the vaccine to thousands of children during the late eighteenth and early nineteenth centuries and in Paraguay the strong man, José Gaspar de Francia, ensured that the vaccine was administered routinely between 1805 and $1806 .{ }^{53}$ As part of this same campaign, the vaccine arrived in Buenos Aries in 1805 and records note that specific sectors of the population received the treatment within the first decade of the century. ${ }^{54}$ Though the vaccine was available, it is worth remembering that the viceroyalty of Buenos Aires was relatively brief (1776-1810) in comparison to those established

52. MCBA, "Memoria 1883," 121.

53. José G. Rigau-Pérez, "The Introduction of Smallpox Vaccine in 1803 and the Adoption of Immunization of Government Function in Puerto Rico," Hispanic American Historical Review 69, no. 3 (August 1989): 393-423; Reber, "Demographics." For an analysis on the vaccination campaign in the Caribbean see Magda Gomez de Cruz, "Smallpox Vaccination, the Establishment of Vaccination Boards, and State Formation in Venezuela and Cuba in the Nineteenth Century" (Ph.D. diss., Miami: Florida International University, 2008).

54. Catherine Mark and José G. Rigau-Pérez, “The World's First Immunization Campaign: The Spanish Smallpox Vaccine Expedition, 1803-1813," Bulletin of the History of Medicine 83, no. 1 (Spring 2009): 63-94 An instruction manual by an unknown author on how to properly administer the vaccine refers to the immunization of children and specifically mentions that the treatment was routinely given to orphans in Buenos Aires, see Instrucciones para la inoculación vacuna, pamphlet (Buenos Aires: Imprenta Niños Expositos, 1813). 
in Mexico City and Lima and as a result the colonial administration was not as interested in implementing an extensive vaccination campaign. Notwithstanding, in 1809, the need for a mandatory vaccination policy in Buenos Aires was presented to the cabildo by a local physician and priest, Saturnino Segurola. In essence, Segurola's plan suggested the following:

Those that are to be vaccinated are those that have not yet had small pox, nor received the inoculation; for this reason the Alcaldes de Barrio and the heads of households (amos de casa) must be exact in identifying those that are to be vaccinated, compelling those, as is done with the most stubborn people in Europe, a similar stubbornness that is present in this region; and they are to be obligated to present to their Alcades a written statement from me attesting to having received the vaccination, and assure themselves of the results by concurring at my house at a convenient time and declare its legitimacy. Included in those that are to receive the vaccination are those that have received it previously but did not follow these steps for their safety, threatening them with a fine or punishment if not carried out as specified. All of the residents (vecinos) should advise the Alcalde de Barrio thereafter of any child or infant or adult that they may have in their house, especially infants that are at least two months old that I might reprimand them and carry out the aforementioned duties. . . . As for the negros, it is necessary that this Most Excellent Cabildo name a surgeon who I will advise and provide the vaccination when the Junta de Salud gives notice of his arrival. Slave owners and traffickers will present those that are to be vaccinated and pay one peso a head to the cabildo. ${ }^{55}$

Segurola's proposal was approved by the cabildo, however, vaccination efforts were short lived and ended when the revolutionary movement crystalized the following year.

55. Juan Ramon Betran, La organización sanitaria de Buenos Aires durante el virreinato del Río de la Plata (Buenos Aires: A. Guidi Barrarini, 1938), 22-23. 
Over the next seven decades, in general, porteños remained relatively apathetic towards smallpox despite the high death rate caused by the disease. In fact, for many Argentine physicians, the failure to "enjoy the benefits of Jenner's prophylactic" was an indication of an overly ignorant population. In a report from the director of the Administración de Vacuna to municipal authorities in 1873, Dr. Justo Meza questioned the actions of parents who refused to procure the vaccine for their children under the "frivolous pretext that [inoculation] causes extreme pain (se les hace padecer)." Furthermore, Meza argued that unless there was a "severe punishment" ignorance would continue to cloud the minds of the city's inhabitants. ${ }^{56}$ Two years later, Dr. Luis Saenz Peña, president of the Comisión Municipal, referred to the quandary as one of indifference noting that many "mothers would prefer to see their children die rather than visit one of the vaccination offices in search of a cure." Like Meza, Saenz Peña believed that the uninformed practices of the population would not be "remedied without heroic action" and encouraged the Comisión Municipal to consider implementing an ordinance that outlined the provisions for mandatory vaccinations in the city. ${ }^{57}$

For Meza and other hygienists, such a law was the only way to "force the public to receive the reward that the Municipality so generously provides," and further argued that mandatory vaccinations were the only way to "extinguish an enemy as terrible as smallpox." 58 To substantiate their claims, municipal authorities pointed to the work of hygienists who had successfully lobbied for such a law in Great Britain. Following the British, nine other European countries had either passed similar statutes or drafted legislation that was pending approval. Hoping to encourage the Argentine congress to do the same, the intendente of Buenos Aires, Torcuato de Alvear reminded the elected officials that in a twenty-five year period, smallpox had caused more deaths than the yellow fever epidemic of 1871. In his opinion, a mandatory

56. MCBA, “Memoria 1873,” 350-51.

57. MCBA, "Memoria 1875," 46-47.

58. MCBA, "Memoria 1873," 351. 
vaccination law was the only means by which porteños would be spared from the reoccurring devastation caused by the disease. Notwithstanding the benefits of such an initiative, Alvear cautioned against a passive law that merely required proper inoculation. Instead, he called on congress to draft a law that gave the Administración de Vacuna the power to enter into the homes of the city's inhabitants and specifically "penetrate the two thousand conventillos of the capital and vaccinate and revaccinate the sixty thousand individuals who reside within and who are precisely the ones whose ignorance and living conditions establish a higher contingency of mortality." ${ }^{59}$ As if to validate Alvear's premonition, three years after his plea for a compulsory vaccination law and without any action by the nation's legislative body, a smallpox epidemic swept through the city claiming two-thirds of its victims from among the poor who lived in the conventillos. ${ }^{60}$

In the absence of a law outlining mandatory vaccinations, the municipal Comisión de Higiene and subsequently the Asistencia Pública monitored smallpox and the ever-looming threat of the disease in other ways. For example, in 1880 during an epidemic in which there were 832 deaths attributed to smallpox, municipal officials organized a series of inspections and subsequent evacuations in a number of the city's conventillos. On one such raid, 136 tenement dwellers were forced to surrender themselves to municipal authorities and were taken to the Hospital San Roque, the designated clinic for infectious diseases. ${ }^{61}$ As part of another initiative, physicians employed by the Asistencia Pública experimented with "vacuna animal" and "vacuna humana" to determine the effectiveness of the two serums. As part of the test, twelve orphans from the Asilo de Huerfanos — six boys and six girls, ranging in ages from five to twelve years old-were immunized with the serum derived from animals. After a week, doctors concluded that the vaccination had produced negative results and therefore determined to re-vaccinate half of the

59. Emilio R. Coni, Memorias de un médico higienista, 188-89.

60. MCBA, "Memoria 1883," 289.

61. MCBA, "Memoria 1880," 160. 
group, three from each gender, with the vacuna animal and the rest of the children would be vaccinated with the vacuna humana. Within a week, the cohort given the human derived serum had developed at least one "positive pustule" except for one young girl who had already been infected with smallpox and was thus immune to the disease. In his report to the Consejo Municipal, Ramos Mejía concluded that, "it is safe to deduce that after these experiments, the animal derived serum does not have sufficient power to inoculate" and that the vacuna humana was the "true anchor of salvation" from the disease. ${ }^{62}$

At last, recognizing that Congress was unwilling to act, the Concejo Deliberante of the municipality moved forward on its own and on December 6, 1886 passed an ordinance establishing the parameters for mandatory smallpox vaccinations to be carried out under the direction of the Asistencia Pública. Foremost, the legislation stipulated that all infants born in Buenos Aires were to be inoculated within the first six months of life. To ensure that this mandate was fulfilled, the ordinance required that the civil registry offices provide the Asistencia Pública with copies of birth certificates for all newborns. Adults who had not yet received the vaccination were to report to one of the offices of the Administración de Vacuna and thereafter were to be revaccinated every ten years. Additionally, the statute required that all immigrants were to receive the vaccination upon arrival to the country and be revaccinated every ten years. All services associated with vaccination and revaccination would be provided free of cost by municipal doctors, however, parents or guardians who failed to procure the vaccine for children under their custody would be fined ten pesos for the first infraction and twenty pesos for the second violation. ${ }^{63}$

Buttressed by a legal framework for compulsory vaccinations, Ramos Mejía deployed a group of medical teams to immunize the city's population against the dreaded smallpox disease. In the first twelve months following the ordinance, the Asistencia Pública administered the serum

62. MCBA, "Memoria 1883," 200-202.

63. MCBA, “Memoria 1886,” 184-86. 
to 41,548 individuals thus surpassing the combined total vaccinations for the previous two decades. For the most part, porteños complied with the new law as demonstrated by the fact that nearly half of the recipients of the vaccine in 1887 were voluntarily inoculated at one of the twenty neighborhood or sectional offices administered by the Asistencia Pública. At the same time, Ramos Mejía was convinced that a large portion of the population would try to avoid vaccination as they had done in the past. With this in mind, the Asistencia Pública organized vaccination teams to converge upon the conventillos and the seventy-seven public schools under the direction of the municipal government. Throughout 1887 , the teams administered the vaccine to 10,871 students and 7,472 individuals who resided in the city's problematic tenements. ${ }^{64}$

During the five years immediately following the ordinance on compulsory vaccinations, the Asistencia Pública performed an average of 21,792 immunizations per year. As impressive as the number might seem, it must be noted that in 1890 , corresponding to an outbreak of smallpox, over 38,000 porteños were vaccinated whereas in the years before and after the smallpox epidemic the number hovered between 13,000 to 18,000 annual immunizations. ${ }^{65}$ The low rate of immunizations concerned Ramos Mejía, who in his yearly report, reminded the municipal council that when an individual or a family refused to be immunized, whether a fine was paid or not, the choice still jeopardized the wellbeing of the entire society. In consideration of this observation, Ramos Mejía proposed that the ordinance be modified so as to put the burden and oversight of vaccinations on the owners and landlords of the conventillos. ${ }^{66}$

Choosing not to amend the ordinance, the Consejo Municipal instead issued a decree on January 7, 1888 which expanded the power of the Asistencia Pública by giving it greater license to address the disproportionately high rate of smallpox in the tenements. To be certain, the decree was passed in response to yet another outbreak of smallpox in 1887 which resulted in 1,299

64. MCBA, "Memoria 1887," 362.

65. MCBA, “Memoria 1893-1894,” 143.

66. MCBA, “Memoria 1887,” 353-56. 
deaths and was the third deadliest outbreak of the disease in twenty-five years. ${ }^{67}$ The wording of the decree mandated that health inspectors converge upon the conventillos with urgency indicating that, "The best way to administer the vaccination and revaccination in large cities is to first visit the different groups in which the disease reigns." To the Consejo Municipal and hygienists who drafted the decree, the group "of most importance, according to its class and large number" were those who comprised the working-class population living in the "conventillos and casas de inquilinato, in which smallpox takes it largest toll and then spreads to the neighboring homes." 68

Under the direction of the Asistencia Publica, vaccination teams traversed the tenements inoculating the city's poor attempting to "extinguish the origins of disease that are propagated by the living conditions of those that dwell in the conventillos." ${ }^{99}$ To carry out this arduous task, the Administración de Vacunas hired forty-two medical practitioners (practicantes de vacunas) and likewise relied on the assistance of physicians and health inspectors assigned to the various sections or districts of the city. Additionally, in an effort to enlist the help of the masses, the Asistencia Pública repeatedly published the ordinance in the local newspapers and likewise printed and distributed fliers that "invited the heads of families to lend their cooperation to the overall good of the community." 70 The ability of the Asistencia Pública to infiltrate the private domains of the city's inhabitants is evident by the overwhelming number of home vaccinations administered over the subsequent years. In 1893 for example, the Asistencia Pública, under the direction of Dr. Emilo Coni, inoculated 14,982 individuals in their own homes. ${ }^{71}$ Two years later, 29,558 porteños were vaccinated a domocilio representing more than half of all

67. Besio Moreno, "Historia de las epidemias de Buenos Aires," 173.

68. MCBA, "Memoria 1887,” 266.

69. MCBA, "Memoria 1887," 306.

70. MCBA, “Memoria 1889,” 185,188.

71. MCBA, "Memoria 1893-1894," 145-46. 
vaccinations given during the year. ${ }^{72}$ Notwithstanding the success of the initiative, the Asistencia Pública frequently encountered hostility and "tenacious resistance" when carrying out home vaccinations. $^{73}$ In his report to the Consejo Municipal, Ramos Mejía acknowledged that it was unsafe to send the vaccination teams into the conventillos unless they were accompanied by the medical doctor assigned to the neighborhood and a police representative from the corresponding district commissary. ${ }^{74}$ Similarly, José M. Astigueta, Ramos Mejía’s successor, noted that vaccinations a domocilio required the assistance of a municipal health inspector and the local police. In most cases, Astigueta observed that only the "threat of being fined compels [the residents] to be vaccinated, otherwise they would resist." 75 Even when faced with heavy fines or imprisonment, many porteños were still defiant against what they viewed as authority gone awry. In 1909 , vaccination teams canvassed nearly 2,500 city blocks and contacted more than 31,000 individuals. Of that total number, 20,559 refused to be vaccinated and the remaining 11,185 were not at home. Municipal authorities issued citations which in turn compelled 15,549 porteños to visit one of the offices of the Administración de Vacuna to receive the injection while the names and addresses of those that did not respond were submitted for judicial action. ${ }^{76}$

The tendency of porteños to refuse inoculation or to evade the vaccination teams was part of a consistent pattern throughout the late nineteenth and early twentieth centuries. Referring to this behavior, the Intendente Manuel J. Güiraldes commented that, "a large percentage of the people are not immunized either because they are truly not home or they pretend to be absent

72. MCBA, "Memoria 1895," 61.

73. MCBA, "Memoria 1905," 175.

74. MCBA, “Memoria 1887,” 266-67.

75. MCBA, "Memoria 1889," 150 Obligatory vaccinations carried out in the private residences of lower-class Chileans also relied on police support. See Murdock, "Physicians, the State and Public Health," 557.

76. MCBA, "Memoria 1909," 85. 
when the Commission Vaccinator presents himself at their residence." Güiraldes also noted that municipal health inspectors, upon returning to a conventillo to enforce a citation that had been issued during an earlier visit, often discovered that the sought-out tenant had moved. ${ }^{77}$ The elusiveness of the city's inhabitants made it difficult for the Asistencia Pública to fully implement the compulsory vaccination ordinance and of particular concern to municipal authorities was the large number of newborns that failed to receive the serum. To illustrate the problem, of the 40,220 children born in 1907 , over $62 \%$ were not vaccinated simply because the infant did not reside at the address that the parents had provided to the civil registry. ${ }^{78}$ In 1908 , vaccination teams encountered the same evasiveness when 22,472 infants whose "whereabouts were unknown" were not inoculated and failed to be vaccinated within the proscribed year. ${ }^{79}$ In addition to those that vaccination teams could not locate, approximately another 6,700 children were not inoculated against the disease because their parents adamantly "resisted the vaccination." 80

Unlike Rio de Janeiro where an obligatory vaccination law led citizens to violent protests and a failed attempt to overthrow the government, the residents of Buenos Aires merely eluded the authorities. ${ }^{81}$ Upon his appointment to preside over the Asistencia Pública, José María Astigueta lamented that the ordinances governing the agency were "highly deficient" and

77. MCBA, “Memoria 1908," 81.

78. MCBA, “Memoria 1908,” 202.

79. MCBA, "Memoria 1909," 81-86.

80. MCBA, “Memoria 1908,” 202; MCBA, "Memoria 1909,” 81-86.

81. For the Brazilian case, see Teresa Meade, “'Civilizing Rio de Janeiro': The Public Health Campaign and the Riot of 1904," Journal of Social History 20, no. 2 (Winter 1986): 301-22;

Jeffrey D. Needell, “The Revolta Contra Vacina of 1904: The Revolt Against 'Modernization' in Belle-Époque Rio de Janeiro," The Hispanic American Historical Review 67, no. 2 (May 1987): 233-69. 
resonated more with previous eras than they did with the "actual conquests of science and medicine that are available to safeguard the health of the inhabitants of this great metropolis." 82 Similarly, Emilo Coni argued that by 1892 the Asistencia Pública had fallen into a deplorable state of disorganization. In his first report to the Consejo Municipal, Coni observed that it was necessary above all else to resolve the power struggle and "frequent disagreements" between the Asistencia Pública and the Departamento Nacional de Higiene. ${ }^{83}$ Even with significant changes implemented by Coni and his successors, the 1909 Memoria del Consejo Municipal referred to "serious defects" in the organization and implementation of the services provided by the Asistencia Pública ${ }^{84}$ Recognizing these "serious defects", porteños took advantage of a comparatively weak government in which the authority to enforce mandates regulating hygiene and sanitary practices was distributed among several government entities.

\section{Conclusions}

As early as 1888 , two years after the mandatory vaccination law was adopted by the municipal council, Ramos Mejía expressed concern about the inability of the Asistencia Pública to vaccinate what appeared to be a mobile and elusive population. As a solution, the hygienist suggested that the ordinance be modified so as to create a three-month window in which the owners and landlords of the conventillos would be required to provide local health inspectors the immunization certificates for all individuals residing at a specified address. After the stipulated time frame, the landlord would be obligated to evict the tenant, who, without the proper vaccinations, would likely find it difficult to secure future housing until a certificate was properly obtained. Ramos Mejía believed that those who lived in the conventillos would "fiercely resist changing residences" being that they were always trying to "multiply their savings" and avoid

82. MCBA, "Memoria 1888," 41.

83. Emilio R. Coni, Memorias de un médico higienista, 307.

84. MCBA, “Memoria 1909," 59. 
any action that would "cause extraordinary expenses." ${ }^{\prime 85}$ In response to obligatory vaccinations, it appears that porteños were less resistant to changing residences than Ramos Mejía had assumed. Instead, the opposite was true and the mobility of the population proved to be the most viable form of resistance against the intrusion of the state into the private lives of the people.

Despite the passive resistance - either as a result of a highly mobile population or by those who simply refused to be inoculated - the mandatory vaccination law overall proved to be successful. Twenty-five years after the law was passed, the Asistencia Pública administered the vaccine to approximately twelve percent of the city's total population on an annual basis. ${ }^{86}$ As such, the vaccination rate was nearly double the average annual growth rate of the city for the same period of time. Furthermore, the municipal ordinance prepared the way for a compulsory vaccination law that extended beyond Buenos Aires to all of the provinces of the republic. Adopted in 1903, the federal law was modeled after the 1886 statute but included provisions for immigrants entering into any of the nation's ports and also required that a student enrolling in a school receiving federal or state funding provide proof of having been vaccinated for smallpox. Moreover, like the municipal ordinance, the law adopted by Congress prompted a series of vaccination campaigns that sent teams of physicians and medical assistants into Argentine homes to inoculate the population resulting in more than three million vaccinations in the first seven years of the law's existence. Thus the initiative of the porteño hygienists, first tested in the conventillos, found its way to the dwellings of Argentines living in the interior provinces as the process of modernization extended beyond the nation's capital.

85. MCBA, “Memoria 1887,” 353-56.

86. MCBA, "Memoria del Departamento Ejecutivo Municipal de la Capital Federal correspondiente al ejercicio administrativo del año 1910" (Buenos Aires, 1911), XVII. 
Table 4.1

Fines rendered by Municipal Inspectors of Hygiene, 1889-1892

$\begin{array}{rrrc}\text { Year } & \text { Citations } & \text { Amount fined } & \text { Amount Collected } \\ 1889 & 8,274 & \$ 263,512 & \$ 115,616 \\ 1890 & 10,814 & \$ 600,737 & \$ 117,682 \\ 1891 & 5,614 & \$ 342,260 & \$ 118,881 \\ 1892 & 7,270 & \$ 429,934 & \$ 69,587\end{array}$


Image 4.1

Interior Patio of a Conventillo in Buenos Aires, Early Twentieth Century

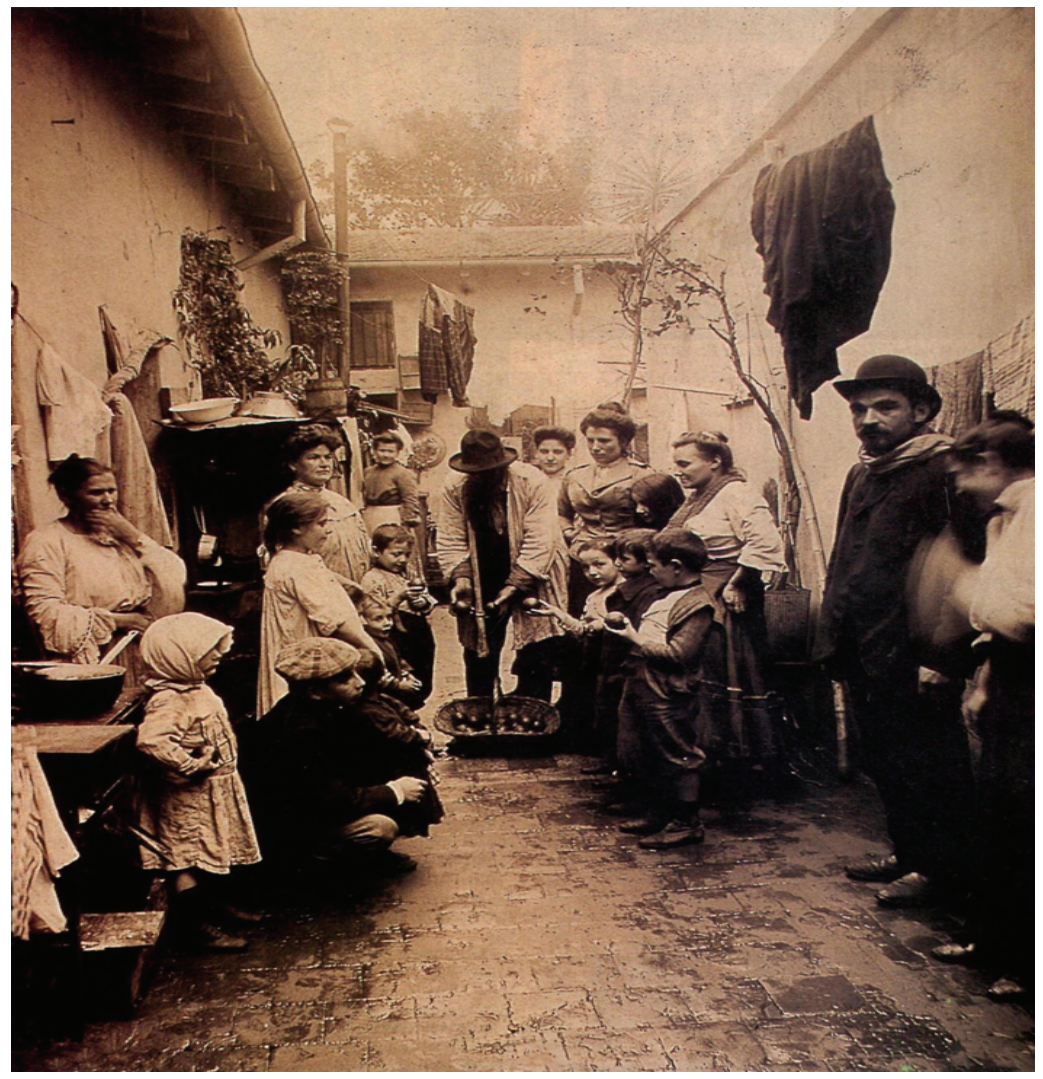




\section{CHAPTER 5}

\section{Conclusions}

The purpose of this study is to examine the nation-building process in Argentina during the late nineteenth and early twentieth centuries through an analysis of the development of the public sphere in the context of public health in Buenos Aires. In doing so, the analysis has focused on the dynamic and complex weave presented by three dimensions: the public sphere-in the sense of political discourse and lively debates in both the press and in the venues of political decision-making - the public space - as observed in the urbanist plans and development of metropolitan Buenos Aires - and the private sphere of homes and households affected by public health policies and practices. The macro-political backdrop against which all three dimensions operated was the still-developing stages of government and governmental capacity in Buenos Aires. Of particular interest are the ways in which these domains reflected and, in turn, were influenced by the discourse of disease and hygiene. In this regard, public opinion, as it related to the conditions of sanitation in the city, was crucial to two processes: first, the physical demonstrations of modernity as expressed in the city's physical transformation, and second, the conceptual transformations in the relationship between the state and the private domain, reified in the creation of formal institutions responsible for health governance. Both dimensions, the urbanist and the political, went through processes of contestation but, in the end, contributed to improving the standards and oversight of public health. 
It is important to note that the transformations mentioned above had their origins in the post-Rosas era of the mid-nineteenth century as the country began the slow process of unification; however, it was the yellow fever epidemic of 1871 in Buenos Aires that propelled the "issues of sanitation to the forefront of public consciousness" and thus grounded the debate regarding public health within the context of the nation-building process. ${ }^{1}$ The first cases of yellow fever developed in the notoriously unsanitary neighborhood of San Telmo and were immediately reported to both the municipal Comisión de Higene and to the state-directed Consejo de Higiene of the province of Buenos Aires. Despite the efforts of the Comisión and the Consejo to quarantine the area, the disease quickly spread from one residence to another in San Telmo and subsequently migrated to a densely populated tenement or conventillo in the barrio of Socorro. Within weeks, the entire city was seized by the deadly plague: by April the death rate exceeded 500 deaths per day. By the end of May, the disease had claimed over 13,000 victims, crippled the economy, paralyzed government services, and caused the evacuation of nearly half of the city's population of approximately 180,000. Writing about the epidemic almost 20 years later, one survivor reminisced that it seemed that the very city died and that the streets of Buenos Aires "during that moment of mourning seemed no different than the silent ruins of Pompeii.", As had occurred during previous outbreaks, the press pushed the subject of disease into the public sphere. In doing so, astute journalists directed the public's attention to the "centers of disease" that were a continual threat to the city and specifically expressed concern over the Riachuelo, cemeteries, slaughterhouses, conventillos, and other areas of the metropolis that repeatedly launched "war-like germs" in the direction of an "undetecting population."” Certain that Buenos Aires was "surrounded by an invisible conspiracy," the press reiterated the need for

1. González Leandri, Curar, persuadir, gobernar, 85.

2. Lucio V. Mansilla, Entre nos causeries del jueves (Buenos Aires, 1889), 229 cited in Ruiz Moreno, La peste histórica, 292.

3. La Prensa, April 24, 1871. 
reform asserting that the unsanitary practices of the population "violated the laws of cleanliness." In an accusatory tone, the press reminded the public that such actions were contrary to the "code of public health" and that any infringement from this unwritten law carried the "penalty of death." ${ }^{4}$ Furthermore, editorials in the daily newspapers were resolute about the necessity of enacting regulations that prevented future epidemics and were more than a cursory response to an immediate threat. Near the end of the outbreak, one editorial in the porteño press noted, "Because the epidemic has claimed hundreds of victims, some of the mentioned areas of concern have been neutralized or destroyed." Notwithstanding, the article speculated that once yellow fever disappeared, "ignorant trust" would again settle upon the "minds of the people" and warned that if the areas of concern were not addressed by the governing agencies, "it would be better for us to demolish our beautiful city and sow it with salt, or petition heaven that mothers become sterile before seeing their progeny fatally condemned to an inevitable and early death."

Though the press had closely monitored earlier occurrences of disease that plagued Buenos Aires, the discourse during the yellow fever epidemic of 1871 was noticeably more compelling. Understandably, the change stemmed in part from the fact that the public's perception of the outbreak was conditioned by the high mortality rate caused by the disease; however, it also corresponded to the emergence of a new group of self-proclaimed hygienists who believed that it was their mission to improve the sanitary condition of the city. Liberally defined, the influential hygienists understood public health as, "everything that refers to the well-being [of the people] and thus encompasses anything that contributes to their physical and moral comfort."

4. "La mortalidad y sus causas," La Revista de Buenos Aires XXIV (1871): 413-25 printed in its entirety in Ruiz Moreno, La Peste Histórica, 343-49.

5. La Prensa, April 24, 1871.

6. Attributed to Eduardo Wilde; see Diego Armus, "El descrubimiento de la enfermedad como problema social," in El progreso, la modernización y sus límites (1880-1916), vol. 5, ed. Mirta Zaida Lobato, Nueva Historia Argentina (Buenos Aires: Editorial Sudamericana, 2000), 513. 
As a result of this broad definition, those who espoused the hygienist agenda argued that the public health of Buenos Aires was not only inherently of great importance for the community, but also more emblematic of progress than any other indicator. As such, the epidemic of 1871 legitimized the rhetoric of forward-thinking medical practitioners who only a few years earlier had claimed that, "Hygiene is, indeed, a basic necessity of a population; its conservation and fomentation must be the primary duty of governments; the hygienic state of a country is the best indicator of its progress and an illustration of what that country has become."7

Increasingly influential during the epidemic of 1871, the press turned its attention to the government institutions entrusted with overseeing public health. Initially optimistic, La Prensa observed that the governing officials of Buenos Aires, "are now realizing that there is something more than their political life .... They are beginning to think about public health, the life of the city." 8 Yet, as the epidemic persisted, the press expressed frustration with what it perceived to be the overwhelming incompetence of public agencies such as the Consejo de Higiene and the Comisión de Higiene and other officials entrusted with protecting the city's population. Based on this perception, one editorial proclaimed, "The day has come when there can be no other question of importance than that of the improving the sanitary condition of Buenos Aires. The best government, the best legislative body, the best political parties will be those that accomplish this task. $^{9}$

The dynamics of the public sphere were further altered when the editors and journalists of the city's newspapers, in conjunction with prominent attorneys, politicians, and other professionals organized a collective response to combat the epidemic. Supported by a broad cross-section of porteño society, the so called Comisión Popular challenged the Consejo de Higiene and the Comisión de Higiene and attempted to place itself in a position of preeminence.

7. "Higiene," 297-98 quoted in González Leandri, Curar, persuadir, gobernar, 65.

8. La Prensa, March 14, 1871.

9. "La peste." 
The potential of civic voluntarism became the representation of the limited efficacy of statecentric solutions. Summarizing public sentiment, a self-congratulatory journalist argued that the "press has raised its voice in unison calling for efficient and quick measures that guarantee the health of the city." Moreover, this writer affirmed that the press "does not want to, nor should it, remain indifferent toward this spectacle that is being repeated with frightening frequency." ${ }^{\prime 10}$ But civic zeal was not enough. Notwithstanding the noble ambitions of the Comisión Popular, strong party loyalties and the excessive pride of some individuals hindered the efforts of the organization and quickly exposed the ideological rifts that eventually destroyed the loose alliance created at the height of the epidemic. Referring to the antics of the Comisión Popular as a "public shame," some of the very newspapers that had initially praised the ad hoc commission questioned the "sterile accusations" of its members and the underlying motives of the group. ${ }^{11}$ Taking advantage of the internal tension within the Comisión Popular, supporters of the Consejo de Higiene utilized segments of the porteño press to realign public opinion thereby solidifying the dominance of the Consejo in the realm of hygiene. Over the next nine years, the Consejo would continue to exert its influence as the premiere authority on matters of public health in Buenos Aires. Elevated to the status of a federal agency in 1880, the Consejo became the National Department of Hygiene and succeeded in cultivating the hygienist discourse both within the federal capital and beyond to the rest of the nation.

As the discourse of disease and public health extended throughout the republic, the hygienist agenda prompted a physical transformation in the public spaces of Buenos Aires. Confronted with unprecedented demographic growth as a result of pro-immigration policies in the late-nineteenth century, the governing elite called for the reconfiguration of the urban landscape through the construction of parks and paseos intended to serve as "lungs" of the city. Commenting on the metaphor, one observer noted that, "there never has been an expression more

10. "La peste” cited in Ruiz Moreno, La peste histórica, 343.

11. La Nación, March 16, 1871. 
applicable. In the interior neighborhoods of the city, where the accumulated population is a source of continual infection, the presence of numerous plants is necessary to purify the air." 12 Acutely aware of the unsanitary conditions of the "modern dwellings" with their "narrow quarters," municipal authorities maintained that the "principles of public hygiene" demanded new parks as being "indispensable" spaces for the relief [desahogo] of the inhabitants of the crowded conventillos. ${ }^{13}$

Beyond the physiological metaphor of the lung, the European-inspired parks and other public spaces became analogous with the "accelerated and uniformly progressive pace" of modernization. ${ }^{14}$ Furthermore, the new green spaces were seen as a way to erase the vestiges of colonial rule and - in the case of the Parque 3 de Febrero and the Jardín Zoológico - the tyranny and despotism associated with the dictatorship of Rosas earlier in the century. Adorned with public art that exuded a sense of culture and an architectural approach that evoked material progress, the public spaces of Buenos Aires became instruments of the nation-building project and of the continuous efforts undertaken to achieve the objective of creating the Argentine citizen. In the simplest of terms, the redesigned spaces were meant to "transform cities and people" thereby contributing to the creation of a new nation. ${ }^{15}$

Originally proposed by Sarmiento in 1872, the Parque 3 de Febrero and the Zoo developed in response to - and in tandem with — the notions of hygiene and modernity that defined the belle époque period in Argentina. Referring to the importance of green spaces as part of the urban landscape, the hygienist Guillermo Rawson remarked, "A park is not a luxury, why should we argue about that? A park is a vital necessity that will save this soon-to-be extensive

12. Attributed to Charles Thays, Director de Paseos of Buenos Aires from 1891 to 1913. Cited in Berjman, Plazas y parques de Buenos Aires, 121.

13. MCBA, "Memoria 1896," 56-57.

14. MCBA, "Memoria 1886," 298.

15. La Nación, February 2, 1934. 
population from epidemics and excessive mortality." Febrero and the Jardín Zoologico would provide "rest and recreation" for "women, adolescents, children, and men of all ages and social conditions." ${ }^{17}$ In addition to the public health benefits, publicity and public awareness were effective in identifying Palermo, the area of the city where the park and the zoo were located, as being "of public interest." For Sarmiento, this transformation was necessary in order to absolve the area from the "monuments of savage tyranny" associated with Rosas's old dwelling that were certain to have condemned the neighborhood to an "inevitable destruction." 18

Notwithstanding the lofty ideals espoused by those who supported the park, critics continually questioned whether the new public space had accomplished its intended purposes. Less than a decade after the park's inauguration, Vicente Quesada noted, “The Parque 3 de Febrero is a very pleasant paseo but it is vacant every day." In Quesada's observation, only on Sundays and holidays was there a "notable concurrence" of people, and even then, the visitors were often distinguished by their "impressive carriages and costly teams of horses."19 Chagrined by the appropriation of the space by the elite, Sarmiento lamented that the "artisans" and "mothers with children" instead of frequenting the park are "merely content knowing that it exists." ${ }^{20}$ In this regard, events in Buenos Aires followed a similar pattern to those in Europe. Writing about the improvements he oversaw in France, Baron Haussmann expressed with some degree of melancholy:

16. Guillermo Rawson, "Escritos y discursos del Dr. Guillermo Rawson," comp. and ed. Alberto B. Martínez (Buenos Aires: Compañia Sud-Americana de Billetes de Banco, 1891), 122.

17. Vicente Quesada, Memorias de un viejo, 65.

18. Sarmiento, "Exposición Agricola" quoted in Gorelik, La grilla y el parque, 71.

19. Vicente Quesada, Memorias de un viejo, 65.

20. El Nacional, October 12, 1882 quoted in Gorelik, La grilla y el parque, 161. 
Despite my best efforts to make the splendid paseos of Paris accessible to all classes of the population, as a result of the distance, time, and cost of transportation I could not manage to promote their use except on Sundays and holidays. ... Instead, during the week these [spaces] — especially the Bois de Boulogne—-became usufruct almost exclusively by the more wealthy, particularly by those who felt they were too noble to do anything worthwhile and instead dedicated the majority of their laziness to the daily exhibition of their riches." 21

Defending their own actions, the elite argued that the under-utilization of the Parque 3 de Febrero indicated the immigrant population's lack of civilized culture. As further proof of this characterization, municipal authorities pointed to vandalism and other destructive behaviors that occurred when the porteño masses frequented the park and the zoo.

Just as class consciousness and nationalism played into the discussion of hygiene and modernization in the city's public spaces, the same rhetoric permeated the discourse on public health and the private domain. With the institutional void created by the designation of the Consejo de Higiene as the National Department of Hygiene, porteño hygienists encouraged the Municipality of Buenos Aires to establish an agency that would oversee all aspects of hygiene, disease prevention, and general medical care. Created in 1883 and overwhelmingly backed by public opinion, the Asistencia Pública followed the precedence set by public health agencies in Europe and extended its reach into the private sphere and the personal lives of porteños. In doing so, it proceeded on the understanding that in monitoring the sanitary condition of the city, it was "endowed with authority to create ordinances, power to enforce them, and jurisdiction over the people and their affairs." 22

21. Quoted in Gorelik, La grilla y el parque, 159.

22. "Discurso del Sr. Sarmiento en la Inauguración de las Aguas Corrientes," Revista Médico Quirúrgica año 5, no. 13 (8 October 1868): 199-201 cited in González Leandri, "La higiene antes de los médicos higienistas," 54. 
With this mind set, prominent hygienists urged municipal and state authorities to address the frequency and intensity of smallpox epidemics that plagued the city. In an effort to account for the reason as to why the number of smallpox deaths in Buenos Aires was comparatively higher than in the urban centers of Europe, the respected hygienist Emilio Coni noted, "The disproportionate mortality is explained by the simple fact that in Europe, vaccination is obligatory. In none of the continental nations of Europe is smallpox as destructive as it is for us in Buenos Aires."23 Despite this realization, initial attempts to establish local or national immunization laws in Argentina during the mid-nineteenth century failed to gain the necessary support for approval. However, when a "great and frightening" smallpox epidemic swept through the city's conventillos in 1883 , eventually claiming 1,488 lives, the municipal council acted by adopting measures in 1886 that authorized the Asistencia Pública to carry out mandatory vaccinations and revaccinations among the porteño population. ${ }^{24}$

Under the direction of José María Ramos Mejía, founding director of the Asistencia Pública, vaccination teams infiltrated the city's conventillos intent on rectifying the perceived "forgetfulness and indolence" that the city's poor demonstrated towards the dreaded disease. ${ }^{25}$ Wary of the government's actions, some tenement dwellers responded with hostility thus requiring the presence of the local police to ensure that the "resistance completely disappeared." 26

23. Emilio Coni, Contribución al estudio de la viruela en la Provincia de Buenos Aires. Memoria presentada a la Asociación Médica Bonarense (Buenos Aires: Imprenta Pablo E. Coni, 1878), 16.

24. MCBA, "Memoria 1886," 124.

25. J. A. Ledesma, "Consideraciones sugeridas con motivo a los proyectos de vacunación obligatoria," Revista Médica Quirúrgica 15 (1878): 403 as quoted in Silva Di Liscia, "Marcados en la piel: Vacunación y viruela en Argentina (1870-1910)," Ciência \& Saúde Coletiva 16, no. 2 (February 2011).

26. Emilio R. Coni, Código de higiene y medicina legal de la República Argentina para uso de 
In other instances, the working class provided false addresses to the civil registry following the birth of a child or merely relocated from one tenement to the other in order to elude medical practitioners and public health inspectors. Despite the varied forms of opposition, the municipal law proved successful and subsequently prompted national legislation in 1903 requiring mandatory smallpox vaccinations throughout the republic.

As demonstrated in this study, the rhetoric of disease and public health became a permanent fixture in the debates that shaped the process of modernization in Argentina following the yellow fever epidemic of 1871. Perhaps this was nowhere more evident than in the convergence of the public sphere, public space, and the private domain in Buenos Aires and the subsequent creation of state institutions that relied on the principles of hygiene to transform the urban landscape and its inhabitants. As noted by one scholar:

The discourse and culture of hygiene and of the hygienist was promoted by educators, physicians, and bureaucrats, and by liberals, anarchists, socialists, radicals, Catholics and even conservatives who were active in social reform. Hygiene was, more so than education, a subject that invited consensus. It defined a territory in which the political ideologies mattered little. The hygienist doctrine offered a tool to be incorporated into the modern city. In fact, it was not an Argentine peculiarity; throughout the nineteenth century, in Europe and the United States, the idea of needing to protect collective and individual hygiene became increasingly sophisticated."27

Once refined in Buenos Aires, prominent hygienists disseminated the liberal interpretations of disease and public health throughout the interior provinces of the country. In this manner, the

médicos, abogados, farmecéuticos, etc. (Buenos Aires: Librería de Juan Etchepareborda, 1891), 648 .

27. Diego Armus, "La enfermedad como problema social," 545. 
positivist notions of hygiene gained relevance and found their way into the nation-building discourse that defined Argentina's formative years.

Extending beyond the belle epoque period, the constructs of hygiene and public health directed the political agenda of the governing elite throughout the first half of the twentieth century and eventually helped frame many of the social reforms initiated by President Juan Perón following World War II. For example, the Plan Quinquenal or Five-Year Plan introduced by Perón in 1946 specifically addressed the deficiencies in health care and sanitation that often hindered progress. As a result, the populist political environment was defined by the construction of new clinics and hospitals, the implementation of radical social insurance programs, and widespread infrastructure projects that provided running water and sewer connections to a larger percentage of the population. Thus in many ways, the "New Argentina" conceived by Perón was founded on the discourse articulated by the nation's first hygienists decades earlier. Not surprisingly, that same discourse - established on the dichotomous interaction between disease and hygiene - continues to influence the Argentine public sphere and in so doing shapes the overall debate on modern-day health initiatives. 


\section{LIST OF REFERENCES}

Primary Sources:

Congreso Nacional. "Diaro de Sesiones de 1874.” Cámara de Senadores. Buenos Aires, 1874. La Revista de Buenos Aires-Historia Americana Literatura y Derecho, 1871.

La Revista de Buenos Aires-Historia Americana Literatura y Derecho, 1871.

Municipalidad de la Ciudad de Buenos Aires. Censo General de la Población, Edificación, Comercio é Industrias de la Ciudad de Buenos Aires, Levantado en los Días 17 de Agosto y 15 y 30 de Setiembre de 1887. Buenos Aires, 1889.

-----. Censo General de la Población, Edificación, Comercio é Industrias de la Ciudad de Buenos Aires, Levantado en los Días 11 y 18 de Septiembre de 1904. Buenos Aires, 1906.

-----. "Memoria de la Ciudad de Buenos Aires correspondiente al año 1873." Imprenta Jorge E. Cook, 1874.

------. “Memoria de la Intendencia Municipal 1890-1892.” Buenos Aires, 1894.

------. “Memoria de la Intendencia Municipal; Año 1903.” Buenos Aires, 1904.

------. “Memoria de la Intendencia Municipal; año 1905.” Buenos Aires, 1906.

------. "Memoria de la Intendencia Municipal de Buenos Aires correspondiente a 1908." Buenos Aires: G. Kraft, 1909.

"Memoria de la Intendencia Municipal de Buenos Aires correspondiente al año 1909." Buenos Aires: G. Kraft, 1910.

------. "Memoria de la Intendencia Municipal de la Capital de la República correspondiente a 1886, presentada al Honorable Concejo Deliberante." Buenos Aires: M. Biedma, 1887.

------. "Memoria de la Intendencia Municipal de la Capital de la República correspondiente a 1887, presentada a H. Concejo Deliberante.” Buenos Aires, 1888.

------. "Memoria de la Intendencia Municipal de la Capital de la República correspondiente a 1888, presentada a H. Concejo Deliberante." Buenos Aires: Sud America, 1889.

"Memoria de la Intendencia Municipal de la Ciudad de Buenos Aires correspondiente a 1883, presentada al H. Concejo Deliberante." Buenos Aires, 1884.

------. "Memoria de la Intendencia Municipal de la Ciudad de Buenos Aires correspondiente a 1884, presentada al Honorable Concejo Deliberante." Buenos Aires, 1885.

------. "Memoria de la Intendencia Municipal de la Ciudad de Buenos Aires correspondiente a 1885, presentada al H. Concejo Deliberante.” Buenos Aires, 1886. 
------. "Memoria de la Intendencia Municipal de la Ciudad de Buenos Aires correspondiente a 1889, presentada al H. Concejo Deliberante por el Intendente Seeber.” Buenos Aires, 1891.

"Memoria del Departamento Ejecutivo Municipal de la Capital Federal correspondiente al ejercicio administrativo del año 1910." Buenos Aires, 1911.

------. "Memoria del Presidente de la Comisión Municipal al Concejo correspondiente a 1876." Buenos Aires: Imprenta Nacional, 1877.

------. "Memoria del Presidente de la Comisión Municipal al Concejo correspondiente al ejercicio 1880; febrero de 1881." Buenos Aires, 1881.

------. "Memoria del Presidente de la Comisión Municipal al Concejo correspondiente al ejercicio de 1878." Buenos Aires, 1879.

------. "Memoria del Presidente de la Comisión Municipal al Concejo correspondiente al ejercicio de 1879; febrero de 1880." Buenos Aires, 1880.

------. "Memoria del Presidente de la Comisión Municipal al Concejo correspondiente al ejercicio de 1880.” Buenos Aires: Imprenta Martin Biedma, 1881.

------ "Memoria del Presidente de la Comisión Municipal al Concejo correspondiente al ejercicio de 1881.” Buenos Aires: Imprenta M. Biedma, 1882.

------. "Memoria del Presidente de la Comisión Municipal al Concejo, correspondiente al ejercicio de 1882; marzo de 1883." Buenos Aires, 1883.

-----.. "Memoria del Vice Presidente de la Comisión Municipal al Concejo.” El Nacional, 1876.

------. "Memoria Presentada al Concejo Deliberante por el Intendente Municipal Señor Emilio V. Bunge; Año 1895.” Buenos Aires, 1896.

------. "Memoria presentada al H. Concejo Deliberante por el Intendente Municipal Dr. Francisco Alcobendas; año 1896.” Buenos Aires, 1897.

------. "Memoria presentada al H. Concejo Deliberante por el Intendente Municipal Dr. Francisco Alcobendas; año 1896.” Buenos Aires: Sud-America, 1898.

------. "Memoria presentada por el Intendente Municipal Dr. Federico Pinedo; años 1893 y 1894 (enero a julio)." Buenos Aires, 1895.

Revista Médico Quirúrgica año I, no. 2 (23 April 1864).

Revista Médico Quirúrgica año III, no. 3 (8 May 1866).

Revista Médico Quirúrgica año V, no. 13 (8 October 1868).

Revista Médico Quirúgica 6 (1869). Buenos Aires: Publicación Quincenal, Órgano de los Intereses Médicos Argentinos.

Revista Médico Quirúrgica año VIII, no. 1 (8 April 1871). 
Revista Médico Quirúrgica año VIII, no. 5 (8 June 1871).

Newspapers:

El Diario

El Mosquito.

La Fronda

El Nacional.

La Nación

La Prensa.

La República.

La Tribuna.

La Vanguardia.

Secondary Sources:

Abel, Christopher. Health, Hygiene and Sanitation in Latin America, 1870-1950. London: University of London, 1996.

Adams, Paul C. "Cyberspace and Virtual Places.” Geographical Review 87, no. 2 (April 1997): 155-71.

Agostina, Claudia. Monuments of Progress: Modernization and Public Health in Mexico City, 1876-1910. Calgary: University of Calgary Press, 2003.

Agostoni, Claudia. "Discurso médico, cultura higiene y la mujer en la ciudad de México al cambio del siglo (XIX-XX)." Mexican Studies/Estudios Mexicanos 18, no. 1 (Winter 2002): $1-22$.

-----. "Sanitation and Public Works in Late Nineteenth Century Mexico." Quipu: Revista Latinoamericana de Historia de las Ciencias y la Tecnologia 12, no. 2 (1999): 187-201.

Alberdi, Juan Bautista. Bases y puntos de partida para la organización de la República Argentina. Buenos Aires: Grupo Editor de America Latina, 1979.

Alchon, Suzanne Austin. Native Society and Disease in Colonial Ecuador. Cambridge: Cambridge University Press, 1992.

Aliano, David. "Curing the Ills of Central America: The United Fruit Company's Medical Department and Corporate America." Estudios Interdisciplinarios de America Latina y el Caribe 17, no. 2 (2007): online. 
Almandoz Marte, Arturo, ed. Planning Latin America's Capital Cities, 1850-1950. New York: Routledge, 2002.

Alvarez, Adriana. "Resignificando los conceptos de la higiene: El surgimiento de una autoridad sanitaria en Buenos Aires de los años 80.” Historia, Ciências, Saúde-Manguinhos 6, no. 2 (July/October 1999): 293-314.

Alvarez, Fernando. La viruela y la vacuna en la República Argentina. Buenos Aires: Caras y Caretas, 1916.

Alvaro Barros-Lémez. "Ciudad, prensa y literatura en 900 rioplatense.” Revista de Crítica Literaria Latinoamerica Año 11, no. 21/22 (1985): 137-49.

Anderson, Robin L. "Public Health and Public Healthiness, São Paulo, Brazil, 1879-1893." Journal of the History of Medicine and Allied Sciences 41, no. 3 (1986): 293-307.

Anker, Peder. “The Bauhaus of Nature.” Modernism/modernity 12, no. 2 (April 2005): 229-51.

Annino, Antonio, ed. De los imperios a las naciones: Iberoamérica. Zaragoza: IberCaja, 1994.

------, comp. Historia de las elecciones de Iberoamérica, siglo XIX. Buenos Aires: Fondo Cultural Económico, 1995.

Appelbaum, Nancy, and Anne S. Macpherson, eds. Race and Nation in Modern Latin America. Chapel Hill, NC: University of North Carolina Press, 2003.

Aráoz Alfaro, Gregorio. "Organización de la lucha social contra la tuberculosis.” La Doble Cruz 1, no. 2 (October 1936).

Ariès, Philippe, ed. "Western Attitudes Towards Death from the Middle Ages to the Present." Translated by Patricia M. Ranum. Baltimore: The Johns Hopkins University Press, 1974.

------. Centuries of Childhood: A Social History of Family Life. New York: Knopf, 1962.

------. Passions of the Renaissance. A History of Private Life. Cambridge, Mass.: Belknap Press of Harvard University Press, 1988.

Ariès, Philippe, and Georges Duby. A History of Private Life: Revelations of the Medieval World. A History of Private Life. Cambridge, Mass.: Belknap Press of Harvard University Press, 1988.

Armus, Diego, ed. Disease in the History of Modern Latin America: From Malaria to AIDS. Durham, NC: Duke University Press, 2003.

-----, ed. Entre médicos y curanderos: cultura, historia y enfermedad en la América Latina. Buenos Aires: Grupo Editorial Norma, 2002.

-----. La ciudad impura: Salud, tuberculosis y cultura en Buenos Aires, 1870-1950. Buenos Aires: Edhasa, 2007.

------. "Consenso, conflicto y liderazgo en la lucha contra la tuberculosis: BuenosAires, 18701950." In La cuestión social en la Argentina, 1870-1943, edited by Juan Suriano, 191216. Buenos Aires: La Colmena, 2000. 
------. “El descrubimiento de la enfermedad como problema social.” In El progreso, la modernización y sus límites (1880-1916), vol. 5, edited by Mirta Zaida Lobato. Nueva Historia Argentina, 507-51. Buenos Aires: Editorial Sudamericana, 2000.

"La idea del verde en la ciudad moderna: Buenos Aires, 1870-1940." Entrepasados 5, no. 10 (1996): 9-22.

------. "Salud y anarquía: la tuberculosis en el discurso libertario argentino, 1870-1940.” In Salud, cultura y sociedad en América Latina, edited by Marcos Cueto, 111-33. Lima: Instituto de Estudios Peruanos, 1996.

------. “Tango, Gender, and Tuberculosis in Buenos Aires, 1900-1940.” In Disease in the History of Modern Latin America: From Malaria to AIDS, edited by Diego Armus, 101-29. Durham, NC: Duke University Press, 2003.

Arrieta, Rafael Alberto. Centuria porteña; Buenos Aires según los viajeros extranjeros del siglo XIX. Buenos Aires: Espasa-Calpe, 1944.

Baer, James A. "Tenant Mobilization and the 1907 Rent Strike in Buenos Aires." The Americas 49, no. 3 (January 1993): 343-68.

Baily, Samuel L. "Patterns and Immigrant Assimilation in Buenos Aires, 1882-1923." Hispanic American Historical Review 60, no. 1 (February 1980): 32-48.

Baker, Keith Michael. Inventing the French Revolution: Essays on French Political Culture in the Eighteenth Century. Cambridge: Cambridge University Press, 1990.

Barnes, Trevor. The Logics of Dislocation: Models, Metaphors, and Meanings of Economic Space. New York: Guilford Press, 1996.

Barnes, Trevor, and J.S Duncan, eds. Writing Worlds: Discourse, Text and Metaphor in the Representation of Landscape. London: Routledge, 1992.

Beccar Varela, Adrián. Torcuato de Alvear, Primer Intendente Municipal de Buenos Aires. Buenos Aires: G. Kraft, 1926.

Benchimol, Jaime. Dos micróbios aos mosquitos: Febre amarela e a revolução no Brasil. Rio de Janeiro: Editora Fiocruz, 1999.

Berco, Cristian. "Silencing the Unmentionable: Non-Reproductive Sex and the Creation of a Civilized Argentina." The Americas 58, no. 3 (January 2002): 419-41.

Berger, Tamar. "Sleep, Teddy Bear, Sleep Independence Park, Petach Tikva: An Israeli Realm of Memory." Israel Studies 7, no. 2 (Summer 2002): 1-32.

Berjman, Sonia. "Los espacios verdes de Buenos Aires entre 1880 y 1925.” Ph.D. diss. Buenos Aires: Facultad de Filosofía y Letras, Universidad de Buenos Aires, 1987.

------ Plazas y parques de Buenos Aires: La obra de los paisajistas franceses. Buenos Aires: Fondo de Cultura Económica, 1998. 
Besio Moreno, Nicolás. "Historia de las epidemias de Buenos Aires: Estudio demográfico y estadístico." In Públicaciones de la Cátedra de la Historia de Medicina, vol. III. Buenos Aires: Universidad de Buenos Aires, 1940.

Betran, Juan Ramon. La organización sanitaria de Buenos Aires durante el virreinato del Río de la Plata. Buenos Aires: A. Guidi Barrarini, 1938.

Billington, James H. Fire in the Minds of Men: Origins of the Revolutionary Faith. New York: Basic Books, 1980.

Black, Max. The Importance of Language. Ithaca: Cornell University Press, 1969.

------. Models and Metaphors. Ithaca, New York: Cornell University Press, 1962.

Bliss, Katherine. "The Science of Redemption: Syphilis, Sexual Promiscuity, and Reform in Revolutionary Mexico." Hispanic American Historical Review 79, no. 1 (February 1999): 1-40.

Bloom, Khaled J. The Mississippi Valley's Great Yellow Fever Epidemic of 1878. Baton Rouge: Louisiana State University Press, 1993.

Blum, Edward J. "The Crucible of Disease: Trauma, Memory, and National Reconciliation During the Yellow Fever Epidemic of 1878." The Journal of Southern History 69, no. 4 (November 2003): 791-820.

Bonilla, Elsy. Salud y desarollo: Aspectos socoeconómicos de la malaria en Colombia. Bogotá: Universidad de los Andes, 1991.

Bordi, Olga N. Cólera e inmigración, 1880-1900. Buenos Aires: Editor Leviatán, 1992.

Bourdé, Guy. "La condition ouvière à Buenos Aires à la fin du XIXe et au début du XXe siècle." Le Mouvement Social 84 (July-September 1973): 3-33.

Breunig, Charles. The Age of Revolution and Reaction. New York: Norton, 1970.

Brown, Jonathon C. "Revival of the Rural Economy and Society in Buenos Aires." In Revolution and Restoration: The Rearrangement of Power in Argentina, 1776-1860, edited by Mark Szuchman and Jonathon C. Brown. Lincoln: University of Nebraska Press, 1994.

Bucich Escobar, Ismael. Bajo el horror de la epidemia: Escenas de la fiebre amarilla de 1871 en Buenos Aires. Buenos Aires, 1932.

------. Visiones de la Gran Aldea. Buenos Aires hace sesenta años. Buenos Aires, 1932.

Bunkley, Allison William. Vida de Sarmiento. Buenos Aires: Editorial Universitaria de Buenos Aires, 1966.

Calhoun, Craig. “Civil Society of Public Life.” Contemporary Sociology 19, no. 2 (1990): 31216.

Cambaceres, Eugenio. En la sangre. Buenos Aires: Ediciones Colihue, 1887.

Carr, Stephen. Public Space. Cambridge: Cambridge University Press, 1992. 
Carrigan, Jo Ann. The Saffron Scourge: A History of Yellow Fever in Louisiana, 1796-1905. Lafayette: University of Southwestern Louisiana, 1994.

------. "Yellow Fever in New Orleans, 1853: Abstractions and Realities." The Journal of Southern History 25, no. 3 (August 1959): 339-55.

Casias de Corne, Alicia Elena, Fiz Antonio Fernández, and Julio Lardies González. Panorama Histórico de la Médicina Argentina. Buenos Aires: Todo Es Historia, S.R.L, 1977.

Censer, Jack Richard, and Jeremy Popkin, eds. Press and Politics in Pre-Revolutionary France. Berkeley: University of California Press, 1987.

Chalhoub, Sidney. "The Politics of Disease Control: Yellow Fever and Race in Nineteenth Century Rio de Janeiro.” Journal of Latin American Studies 25, no. 3 (October 1993): 441-63.

Chartier, Roger, ed. A History of Private Life: Passions of the Renaissance. A History of Private Life. Cambridge, Mass.: Belknap Press of Harvard University Press, 1987.

------. The Cultural Origins of the French Revolution. Durham, N.C.: Duke University Press, 1991.

Cirvini, Silivia. "La ciudad en el discurso sarmiento." Ambas Américas 5 (September/October 1992): 78-100.

Coni, Emilio. Contribución al estudio de la viruela en la Provincia de Buenos Aires. Memoria presentada a la Asociación Médica Bonarense. Buenos Aires: Imprenta Pablo E. Coni, 1878.

Coni, Emilio R. Código de higiene y medicina legal de la República Argentina para uso de médicos, abogados, farmecéuticos, etc. Buenos Aires: Librería de Juan Etchepareborda, 1891.

-----. Memorias de un médico higienista: Contribución a la historia de la higiene pública y social Argentina. Buenos Aires: Talleres Graficos A. Flaiban, 1918.

Connor, Michael E. "El dominio de la fiebre amarilla en el Ecuador." In La fiebre amarilla y los médicos de Guayaquil. Guayaquil: Archivo Historico de Guayas, 1987.

Contrera Cruz, Carlos. "Ciudad y salud en el Porfiriato: La política urbana y de saneamiento de Puebla, 1880-1906.” Siglo XIX 1, no. 3 (1992): 55-76.

Cook, Noble David. Born to Die: Disease and New World Conquest, 1492-1650. Cambridge: Cambridge University Press, 1998.

Cook, Noble David, and W. George Lovell. "Unraveling the Web of Disease." In The Secret Judgments of God: Native Peoples and Old World Disease, edited by Noble David Cook and W. George Lovell, 215-44. Norman: University of Oklahoma Press, 1992.

Corbière, Emilio J. La masonería: política y sociedades secretas. Buenos Aires: Editorial Sudaméricana, 1998. 
Costeloe, Michael P. The Central Republic in Mexico, 1835-1846: Hombres de bien in the Age of Santa Anna. Cambridge: Cambrdge University Press, 9993.

Cottrol, Robert J. "Beyond Invisibility: Afro-Argentines in Their Nation's Culture and Memory." Latin American Research Review 42, no. 1 (2007): 139-56.

Coutinho, Marilia. “Tropical Medicine in Brazil: The Case of Chagas' Disease." In Disease in the History of Modern Latin America: From Malaria to Aids, edited by Diego Armus, 76100. Durham, NC: Duke University Press, 2003.

Cranz, Gilden. The Politics of Park Design: A History of Urban Parks in America. Cambridge, Ma.: Harvard University Press, 1982.

Cresswell, Tim. "Weeds, Plagues, and Bodily Secretions: A Geographical Interpretation of Metaphors of Displacement." Annals of the Association of American Geographers 87, no. 2 (June 1997): 330-45.

Crider, Ernest Allen. "Modernization and Human Welfare: The Asistencia Pública and Buenos Aires, 1882-1910." Ohio State University, 1975.

------. "Modernization and Human Welfare: The Asistencia Pública and Buenos Aires, 18831910." Ph.D. diss. Ohio State University, 1976.

Crosby, Alfred W. The Colombian Exchange: Biological and Cultural consequences of 1492. Westport, CT: Greenwood Press, 1972.

------. "Conquistador y Pestilencia: The First New World Pandemic and the Fall of the Great Indian Empires." Hispanic American Historical Review 47 (1967): 321-37.

Crosby, Molly Caldwell. The American Plague: The Untold Story of Yellow Fever, the Epidemic that Shaped Our History. New York: Berkeley Books, 2006.

Cueto, Marcos, ed. Salud, cultura y sociedad en América Latina. Washington, D.C.: Organización Panamericana de la Salud, 1996.

------. "Identidad regional y malaria en el Perú del siglo XX." In El regreso de las epidemias: Salud y sociedad en el Perú del siglo XX, edited by Marcos Cueto, 127-72. Lima: IEP, 1997.

------. El regreso de las epidemias: Salud y sociedad en el Perú del siglo XX. Lima: Instituto de Estudios Peuranos, 1997.

-----. "Sanitation from Above: Yellow Fever and Foreign Intervention in Peru, 1919-1922.” The Hispanic American Historical Review 72, no. 1 (February 1992): 1-22.

------. "Tropical Medicine and Bacteriology in Boston and Peru: Studies of Carrion's Disease in the Early Twentieth Century." Medical History 40 (1996): 344-64.

Darnton, Robert. The Business of Enlightenment: A Publishing History of the "Encyclopédie," 1775-1800. Cambridge, Mass.: Harvard University Press, 1979.

Darnton, Robert, and Daniel Roche, eds. Revolution in Print: The Press in France, 1775-1800. Berkeley: University of California Press, 1989. 
Davidson, Donald. "What Metaphors Mean.” Critical Inquiry 5 (Autumn 1978): 31-47.

Davie, John Constanse. Letters from Paraguay: Describing the settlements of Montevideo an [d] Buenos Ayres; the presidencies of Rioja Minor, Nombre de Dios, St. Mary and St. John, with the manners, customs, religious ceremonies of the inhabitants: written during a residence of seventeen months in that country. London: G. Robinson, 1805.

de Tezanos, Jacob. "Infección y contagio.” Universidad de Buenos Aires, 1872.

Delaporte, François. The History of Yellow Fever: An Essay on the Birth of Tropical Medicine. Cambridge: MIT Press, 1991.

Denevan, William M. "Native American Populations in 1492: Recent Research and a Revised Hemispheric Estimate." In The Native Populations of the Americas in 1492, edited by William M. Denevan, xvii-xxxviii. Madison: University of Wisconsin Press, 1992.

Derrida, Jacques. Margins of Philosophy. Translated by Alan Bass. Chicago: Chicago University Press, 1982.

Domosh, Mona. "Those 'Gorgeous Incongruities': Polite Politics and Public Space on the Streets of Nineteenth-Century New York City." Annals of the Association of Geographers 88, no. 2 (June 1998): 209-26.

Doncel, Salvador. "La fiebre amarilla de 1871 observada en el Lazareto Municipal de San Roque." Biblioteca de la Facultad de Medicina: Universidad de Buenos Aires, 1872.

Dreher, Nan H. "The Virtuous and the Verminous: Turn-of-the-Century Moral Politics in London's Public Parks." Albion: A Quarterly Journal Concerned with British Studies 29, no. 2 (Summer 1997): 246-67.

Duffy, John. Epidemics in Colonial America. Baton Rouge: Louisiana State University Press, 1953.

-----. "Smallpox and the Indians in the American Colonies." Bulletin of the History of Medicine 25 (1951): 324-41.

------. Sword of Pestilence: The New Orleans Yellow Fever Epidemic of 1853. Baton Rouge: Louisiana State University Press, 1966.

Duhau, Emilio, and Angela Giglia. "Conflictos por el espacio y orden urbano." Estudios Demográficos y Urbanos 19, no. 2 (May-August 2004): 257-88.

Dwyer, William J. "Buenos Aires Under Terror: A Case Study of the Yellow Fever Epidemic of 1871.” Medical Library: Yale University, 1992.

Echegaray, Miguel. "Fiebre amarilla del año 1871." Biblioteca de la Facultad de Medicina: Universidad de Buenos Aires, 1872.

Eco, Umberto. “The Scandal of Metaphor.” Poetics Today 4 (1984): 87-129.

Einhalter, Helmut, ed. Jakobiner in Mitteleuropa. Innsbruck: Inn-Verl, 1977. 
Eisenstein, Elizabeth L. Print Culture and Enlightenment Thought. Chapel Hill: University of North Carolina Press, 1986.

Ellis, John. Yellow Fever and Public Health in the New South. Lexington: University of Kentucky Press, 1992.

Eyherabide, Rodolfo. "Repercusión en Barracas al Sur de la 'Peste Histórica de 1871'.” Boletin del Archivo Nacional de Medicina 49, no. 2 (1971).

Estadística de la mortalidad ocasionada por la epidemia de fiebre amarilla durante los meses de enero, febrero, marzo, abril, mayo y junio de 1871. Buenos Aires: Impresa del Siglo y de La Verdad, 1873.

Facciolo, Ana María. "Crecimiento industrial, expansión metropolitana y calidad de vida: El asentamiento obrero en la Región Metropolitana de Buenos Aires desde principios del siglo." Desarrollo Econónico 20, no. 80 (January-March 1981): 549-68.

Farrar, Margaret E. "Health and Beauty in the Body Politic: Subjectivity and Urban Space," 1.23,2000 .

Felstiner, Mary Lowenthal. "Family Metaphors: The Language of Independence Revolution." Comparative Studies in Society and History 25, no. 1 (January 1983): 154-80.

Findlay, Eileen J. Suárez. Imposing Decency: The Politics of Sexuality and Race in Puerto Rico, 1870-1920. Durham, NC: Duke University Press, 1999.

Fonso Gandolfo, Carlos. "La epidemia de fiebre amarilla de 1871.” In Públicaciones de la Cátedra de Historia de la Medicina, vol. III. Buenos Aires: Universidad de Buenos Aires, 1940.

Foucault, Michel. The Birth of the Clinic: An Archaeology of Medical Perception. London: Tavistock, 1973.

-----. Discipline and Punish: The Birth of the Prison. New York: Pantheon, 1977.

François, Etienne. Sociabilité et société bourgeoise en France, en Allemagne et en Suisse, 17501850: Geselligkeit, Vereinswesen und bürgerliche Gesellschaft in Frankreich, Deutschland und der Schweiz, 1750-1850. Paris: Recherche sur les civilisations, 1986.

Fraser, Nancy. "Rethinking the Public Sphere: A Contribution of Actually Existing Democracy." In Habermas and the Public Sphere, edited by Craig Calhoun. Cambridge: MIT University Press, 1991.

Frías Núñez, Marcelo. Enfermedad y sociedad en la crisis colonial del antiguo régimen Nueva Granada en el transito del siglo XVIII al XIX: las epidemias de viruela. Madrid: Consejo Superior de Investigaciones Científicas, 1992.

Fuente, Ariel de la. Children of Facundo: Caudillo and Gaucho Insurgency During the Argentine State-Formation Process. Durham: Duke University Press, 2000.

-----. "Facundo and Chacho in Songs and Stories: Oral Culture and the Representations of Caudillos in the Nineteenth-Century Interior." Hispanic American Historical Review 80, no. 3 (August 2000): 503-35. 
Furet, François. Interpreting the French Revolution. Elborg Forster. Cambridge: Cambridge University Press, 1981.

Furley, David J., and Alexander Nehamas. Aristotle's Rhetoric: Philosophical Essays. Princeton: Princeton University Press, 1994.

Gandía, Enrique de. La independencia de América y las sociedades secretas. Santa Fe: Ediciones Sudamérica Santa Fe, 1994.

Garavaglia, Juan Carlos. "Elecciones y luchas políticas en los pueblos de la campaña de Buenos Aires: San Antonio de Acero (1813-1844)." Boletín del Instituto de Historia Argentina y Americana "Dr. Emilio Ravignani" Tercera seria, no. Num. 27 (1er semestre 2005): 4974.

García, Juan César. "La medicina estatal en América Latina (1880-1930)." Revista Latinoamericana de Salud I (1981): 70-110.

Gentner, Dedre. "Metaphor as Structure Mapping: The Relational Shift." Child Development 59, no. 1 (February 1988): 47-59.

Gibbs, Raymond W. The Poetics of Mind: Figurative Thought, Language, and Understanding. Cambridge: Cambridge University Press, 1994.

González, Andrea Susana. "El impacto de la enfermedad en la organización social y el espacio urbano: El caso de la epidemia de fiebre amarilla en la ciudad de Buenos Aires en 1871." Medicina y Sociedad 24, no. 2: 93-102.

González Bernaldo de Quiros, Pilar. Civilité et politique: Aux origenes de la nation argentine. Paris: Sorbonne, 1999.

------. Civilidad y política en los orgines de la Nación Argentina. Las sociabilidades en Buenos Aires, 1829-1862. Buenos Aires: FCE, 2000.

------. "La Revolución Francesa y la emergencia de nuevas prácticas de la política: La irrupción de la sociabilidad política en el Río de la Plata revolucionario, 1810-1815." In $L a$ Revolución Francesa y Chile, edited by Ricardo Krebs and Christián Gazmuri, 111-35. Santiago de Chile: Editorial Universitaria, 1990.

González Leandri, Ricardo. Curar, persuadir, gobernar: La construcción histórica de la profesión médica en Buenos Aires, 1852-1886. Madrid: Consejo Superior de Investigaciones Científicas, 1999.

-----. Curar, persuadir, gobernar: La construcción histórica de la profesión médica en Buenos Aires: 1852-1886. Madrid: Consejo Superior de Investigaciones Científicas, 1999.

------. "La higiene antes de los médicos higienistas Buenos Aires: 1850-1870.” Desmemoria 5, no. 18 (May/August 1998): 41-56.

Goodman, Deena. "Public Sphere and Private Life: Toward a Synthesis of Current Historiographical Approaches to the Old Regime." History and Theory 31, no. 1 (February 1992): 1-20. 
Gomez de Cruz, Magda. "Smallpox Vaccination, the Establishment of Vaccination Boards, and State Formation in Venezuela and Cuba in the Nineteenth Century." Ph.D. diss. Miami: Florida International University, 2008.

Gorelik, Adrián. La grilla y el parque: espacio público y cultura urbana en Buenos Aires, 1887 1936. Buenos Aires: Universidad Nacional de Quilmes, 1998.

Gravaglia, Juan Carlos. "Elecciones y luchas póliticas en los pueblos de la campaña de Buenos Aires: San Antonio de Areco." Boletín del Instituto de Historia Argentina y Americana "Dr. Emilio Ravagnani, no. 27 (1er semestre 2005): 49-74.

Guerra, François-Xavier. Le Mexique. De l'Ancien Régime à la Révolution. Paris: Harmattan, 1985.

------. Modernidad e independencias: Ensayos sobre las revoluciones hispánicas. Madrid: MAPFRE, 1993.

Guerra, François-Xavier, and Annick Lempériére, eds. Los espacios públicos. Ambigüedades y problemas, Siglos XVII-XIX. Mexico: Fondo Cultural Económico, 1999.

Gumpel, Liselotte. Metaphor Reexamined: A Non-Aristotelian Perspective. Bloomington: Indiana University Press, 1984.

Gutierrez, Ramon, and Sonia Berjman. La Plaza de Mayo: Escenario de la vida argentina. Buenos Aires: Fundación Banco de Boston, 1995.

Gutiérrez, Leandro. "Condiciones de la vida material de los sectores populares en Buenos Aires: 1880-1914.” Revista de Indias 163-164 (Enero-Junio 1981): 167-202.

Guy, Donna J. Sex and Danger in Buenos Aires: Prostitution, Family, and Nation in Argentina. Lincoln: University of Nebraska Press, 1991.

Habermas, Jürgen. The Structural Formation of the Public Sphere: An Inquiry into a Category of Bourgeois Society. Thomas Burger. Cambridge: MIT Press, 1989.

Hadfield, William. Brazil, the River Plate and the Falkland Islands. London: Longman, Brown, Green and Longmans, 1854.

Haussmann, Georges Eugène. Premier mémoire sur les eaux de Paris. Seine, France, 1861.

Hilda Sabato. "Citizenship, Political Participation, and the Formation of the Public Sphere in Buenos Aires 1850s-1880s." Past and Present 136 (August 1992): 139-63.

Hobsbawm, Eric J. The Age of Revolution [Europe], 1789-1848. London: Weidenfeld and Nicholson, 1962.

Hohendahl, Peter Uwe. The Institution of Criticism. Ithaca, N.Y.: Cornell University Press, 1982.

------. "Recasting the Public Sphere." October 73 (Summer 1995): 27-54.

Horn, Margaret. Health, Society and Culture in Latin America. Durham, N.C.: Duke University Press, 1994. 
Huerkamp, Claudia. "The History of Smallpox Vaccination in Germany: A First Step in the Medicalization of the General Public." Journal of Contemporary History 20, no. 4 (October 1985): 617-35.

Hunt, Lynn. Politics, Culture, and Class in the French Revolution. Berkeley: University of California Press, 1984.

Hutton, Patrick H. "The History of Mentalities: The New Map of Cultural History." History and Theory 20, no. 3 (October 1981): 237-59.

Instrucciones para la inoculación vacuna. Pamphlet. Buenos Aires: Imprenta Niños Expositos, 1813.

Im Hof, Ulrich. Das gesellige Jarhundert: Gesellschaft und Gesellschaften im Zeitalter der Aufklärung. München: Beck, 1982.

Jackson, Robert H. Indian Population Decline. The Missions of Northwestern New Spain, 16871840. Albuquerque: University of New Mexico Press, 1994.

Jacob, Margaret C. Living the Enlightenment: Freemasonry in 18th-Century Europe. New York: Oxford University Press, 1992.

------. The Radical Enlightenment: Pantheists, Freemasons, and Republicans. London: Allen and Unwin, 1981.

Jaksić, Iván. The Political Power of the Word: Press and Oratory in Nineteenth-Century Latin America. London: University of London, 2002.

Jardín Zoológico de la Ciudad de Buenos Aires. Buenos Aires Zoo 1888-1998: 110 Aniversario del Jardín Zoológico de la Ciudad de Buenos Aires. Buenos Aires: Juan Milán y Asociados, 1998.

Jarosz, Lucy. "Constructing the Dark Continent: Metaphor as a Geographical Representation of Africa," 1992.

------. "Constructing the Dark Continent: Metaphor as Geographi Representation in Africa." Gografiska Annaler 74, no. 2 (1992): 105-15.

Johnson, Mark. The Body in the Mind: The Bodily Basis of Meaning, Imagination, and Reason. Chicago: University of Chicago Press, 1992.

------. Philosophical Perspectives on Metaphor. Minneapolis: University of Minnesota Press, 1981.

Jones, Gareth. "The Latin American City as Contested Space: A Manifesto." Bulletin of Latin American Research 13 (1994): 1-12.

Kinsburner, Jay. "The Pulperos of Caracas and San Juan during the First Half of the Nineteenth Century." Latin American Research Review 13, no. 1 (1978): 65-85.

Kirby, John. “Aristotle on Metaphor.” The American Journal of Philology 118, no. 4 (Winter 1997): 517-53. 
Kirmayer, Laurence J. “The Body's Insistence on Meaning: Metaphor as Presentation and Representation in Illness Experience." Medical Anthropology Quarterly 6, no. 4 (December 1992): 323-46.

Knaut, Andrew. "Yellow Fever and the Late Colonial Public Health Response in the Port of Veracruz." The Hispanic American Historical Review 77, no. 4 (November 1997): 61944.

Korn, Francis, and Lidia de la Torre. "La vivienda en Buenos Aires 1887-1914." Desarollo Económico 25, no. 98 (Julio-Septiembre 1985): 245-58.

Koselleck, Reinhart. Critique and Crisis: Enlightenment and the Pathogenisis of Modern Society. Cambridge: MIT Press, 1988.

La Vopa, Anthony J. "Conceiving a Public: Ideas and Society in Eighteenth-Century Europe." The Journal of Modern History 64, no. 1 (March 1992): 79-116.

Lakoff, Andrew. "The Simulation of Madness in Buenos Aires, 1903." Critical Inquiry 31, no. 4 (Summer 2005): 848-73.

Lakoff, George, and Mark Johnson. Metaphors We Live By. Chicago: University Chicago Press, 1980.

------. Philosophy in the Flesh: The Embodied Mind and it Challenge to Western Thought. New York: Basic Books, 1999.

Leary, David E. Metaphors in the History of Psychology. New York: Cambridge University Pres, 1990.

Ledesma, J. A. "Consideraciones sugeridas con motivo a los proyectos de vacunación obligatoria.” Revista Médica Quirúrgica 15 (1878).

Liernur, Jorge F., and Graciela Silvestri. El umbral de la metrópolis. Transformaciones técnicas y cultura en la modernización de Buenos Aires (1870-1930). Buenos Aires: Sudamericana, 1993.

Llames Massini, J.C. La partera de Buenos Aires y la Escuela de Parteras. Buenos Aires: Flaiban and Camilloni, 1915.

Llanes, Ricardo M. "Antiguas plazas de la ciudad de Buenos Aires.” Cuaderno de Buenos Aires. Buenos Aires: Municipalidad de la Ciudad de Buenos Aires, 1977.

Loudet, Osvaldo. Ensayos de crítica e historia. Buenos Aires: Academia Argentina de Letras, 1975.

Lovell, W. George. Conquest and Survival in Colonial Guatemala: A Historical Geography of the Cuchumatán Highlands, 1500-1821. Montreal and Kingston: McGill-Queen's University Press, 1992.

Low, Setha. On the Politics of Public Space. Austin: University of Texas Press, 2000.

Lugones, Leopoldo. Historia de Sarmiento. Buenos Aires: Editroial Bajel, 1945. 
Luque, Pedro L. "Apuntes históricos sobre epidemilogía americana, con especial referencia al Rio de la Plata." Revista de la Universidad Nacional de Córdoba (1941). Córdoba.

Lynch, John. Argentine Dictator Juan Manuel de Rosas, 1829-1852. Oxford: Clarendon Press, 1981.

Mabragaña, H. Los Mensajes. Historia del desenvolviemiento de la Nación Argentina redactada cronológicamente por sus gobernantes. 1810-1910. Los Mensajes. Buenos Aires, 1910.

Mac Cormac, E. R. A Cognitive Theory of Metaphor. Cambridge: MIT Press, 1985.

McCall, Marsh H., Jr. Ancient Rhetorical Theories of Simile and Comparison. Cambridge: Harvard University Press, 1969.

Mallo, Pedro, and José Antonio Pillado. Páginas de la historia de la medicina en el Río de la Plata. Buenos Aires: Imprenta Industrial, 1897.

Mansfield, Charles B., and Charles Kingsley. Paraguay, Brazil and the Plate: Letters written in 1852-1853. Cambridge: Macmillan, 1856.

Mansilla, Lucio V. "Entre nos causeries de jueves.” Buenos Airs, 1889.

------. Entre nos causeries del jueves. Buenos Aires, 1889.

Mark, Catherine, and José G. Rigau-Pérez. "The World's First Immunization Campaign: The Spanish Smallpox Vaccine Expedition, 1803-1813." Bulletin of the History of Medicine 83, no. 1 (Spring 2009): 63-94.

Martinez, María Elena. "Space, Order and Group Identities in a Spanish Colonial Town: Puebla de los Angeles." In The Collective and the Public in Latin America: Cultural Identities and Political Order, Luis Roniger and Tamar Herzog, 13-66. Brighton: Sussex Academic Press, 2000.

Martínez Estrada, Ezequiel. La cabeza de Goliat. Buenos Aires, 1946.

Maza, Sara. "Domestic Melodrama as Political Ideology: The Case of the Comte de Sanois." American Historical Review 94, no. 5 (December 1989): 1249-64.

Mead, Karen. "Beneficent Maternalism: Argentine Motherhood in Comparative Perspective, 1880-1920.” Journal of Women's History 12, no. 3 (Autumn 2000): 120-45.

------. "Gendering the Obstacles to Progress in Positivist Argentina, 1880-1920." Hispanic American Historical Review 77, no. 4 (1997): 645-75.

Meade, Teresa. "“Civilizing Rio de Janeiro': The Public Health Campaign and the Riot of 1904." Journal of Social History 20, no. 2 (Winter 1986): 301-22.

-----. “Civilizing” Rio: Reform and Resistance in a Brazilian City, 1889-1930. University Park: Pennsylvania State University Press, 1997.

Melendez, Lucio. La viruela en la campaña: Cuasas de su propagación y de la excesiva mortalidad. Pamphlet. Buenos Aires: Poder Ejecutivo del Consejo Municipal, 1878. 
Miall, David, ed. Metaphor: Problems and Perspectives. Brighton: Harvester Press, 1982.

Molinari, José Luis. "Historia de la medicina desde la presidencia de Mitre hasta la revolución de 1930." In Historia argentina contemporánea, vol. II, Academia Nacional de la Historia, Capítulo VIII. Buenos Aires: Editorial El Ateneo, 1930.

Montero, Belisario J. "La regeneración de los mendigos y vagabundos." Archivos de Psiquiatría, Criminología, y Ciencias Afines 1 (1902): 648.

Montoya, Alfredo J. Historia de los saladeros argentinos. Buenos Aires: Editorial Raigal, 1956.

Moyano Gacitúa, Cornelio. Curso de ciencia criminal y derecho penal argentino. Buenos Aires: Lajouane, 1899.

Murdock, Carl T. "Physicians, the State and Public Health in Chile, 1881-1891." Journal of Latin American Studies 27, no. 3 (October 1995): 551-67.

Muzzio, Julio A. Diccionario histórico biográfico de la República Argentina.

Myers, Jorge. Orden y virtud: el discurso republicano en el régimen rosista. Buenos Aires: Universidad Nacional de Quilmes, 1995.

Myers, Scott. "A Survey of British Literature on Buenos Aires during the First Half of teh 19th Century." The Americas 44, no. 1 (July 1987): 67-79.

Nathans, Benjamin. "Habermas's 'Public Sphere' in the Era of the French Revolution." French Historical Studies 16, no. 3 (Spring 1990): 620-44.

Navarro, Mardoqueo. "La fiebre amarilla de 1870-1871." Anales del Departamento Nacional de Higiene (1894), 447-55.

Needell, Jeffrey D. "Optimism and Melancholy: Elite Response to the Fin de Siècle Bonarense." Journal of Latin American Studies 31, no. 3 (October 1999): 551-88.

------ “The Revolta Contra Vacina of 1904: The Revolt against 'Modernization' in Belle-Époque Rio de Janeiro." The Hispanic American Historical Review 67, no. 2 (May 1987): 23369.

------. "Rio de Janeiro and Buenos Aires: Public Space and Public Consciousness in Fin-DeSiècle Latin America." Comparative Studies in Society and History 37, no. 3 (July 1995): 519-40.

Needler, Martin C. "Metaphors, Models, and Myths in the Interpretation of Mexican Politics." Mexican Studies 7, no. 2 (Summer 1991): 347-57.

Noguera, Carlos E. Medicina y política: discurso médico y prácticas higiénicas durante la primera mitad del siglo XX en Colombia. Medellín, Colombia: Fondo Editorial Universidad EAFIT, 2003.

Nouzeilles, Gabriela. "An Imaginary Plague in Tun-of-the-Century Buenos Aires: Hysteria, Discipline, and Languages of the Body." In Disease in the History of Modern Latin America: From Malaria to AIDS, edited by Diego Armus, 51-75. Durham, NC: Duke University Press, 2003. 
Obregón, Diana. “De 'arbol maldito' a 'enfermedad curable': Los médicos y la construcción de la lepra en Colombia, 1884-1939." In Salud, cultura y sociedad en América Latina, edited by Marcos Cueto, 159-78. Lima: IEP, 1996.

Oliver, Lilia V. "El cólera y los barrios de Guadalajara." In Salud, cultura y sociedad en América Latina, edited by Marcos Cueto, 87-110. Lima: IEP, 1996.

Onelli, Clemente. Idiosincrasias de los pensionistas del Jardín Zoológico: 1908, 1909, 1910. Buenos Aires: Elefante Blanco, 1999.

Ortony, Andrew. Metaphor and Thought. New York: Cambridge University Press, 1993.

Palmer, R. R. The Age of Democratic Revolution: Political History of Europe and America, 1760-1800. Princeton: Princeton University Press, 1959-64.

Parish, Woodbine. Buenos Ayres, and Provinces of the Rio de la Plata. London: J. Murray, 1852.

Parks, Lois F., and Gustave Nuermberger. "The Sanitation of Guayaquil.” Hispanic American Historical Review 23 (Febuary 1943): 197-221.

Peard, Julyan G. Race, Place, and Medicine: The Idea of the Tropics in Nineteenth-Century Brazilian Medicine. Durham, NC: Duk University Press, 2000.

-----. "Tropical Disorders and the Forging of a Brazilian Medical Identity." Hispanic American Historical Review 77, no. 1 (February 1997): 1-44.

Penna, José. Consideraciones sobre los casos de fiebre amarilla importados. Buenos Aires: Imprenta de la Universidad de Buenos Aires, 1883.

------. "Estudio sobre las epidemias de fiebre amarilla en el Río de la Plata.” Anales del Departamento Nacional de Higiene 1, no. Año V (Noviembre 1895). Buenos Aires.

Penna, José, and José María Ramos Mejía. La viruela en la América del Sud y principalmente en la Républica Argentina: historia, estadistica, clinica, y profilaxia. Buenos Aires: F. Lajouane, 1885.

Pesenti, Victor. "La inlfuencia de la civilización sobre el movimiento de la criminalidad." Buenos Aires: Universidad de Buenos Aires, 1901.

Pérez Bertruy, Ramona Isabela. "La modernización de paseos y jardines públicos en la Ciudad de Mexico durante el Profiriato." Paper presented at. Latin American Studies Association XXII International Congress. Miami, FL, 2000.

Pillado, José Antonio. Buenos Aires colonial. Buenos Aires: Compañía Sudamericana de Billetes de Banca, 1910.

Pineo, Ronn F. "Misery and Death in the Pearl of the Pacific: Health Care in Guayaquil, Ecuador, 1870-1925." Hispanic American Historical Review 70, no. 4 (November 1990): 609-37.

Popkin, Jeremy D. Revolutionary News: The Press in France, 1789-1799. Lexington: University Press of Kentucky, 1990. 
Porter, Roy, and Mikulás Teich, eds. The Enlightenment in National Context. Cambridge: Cambridge University Press, 1981.

Powell, J.H. Bring Out Your Dead: The Great Plague of Yellow Fever in Philadelphia in 1793. Philadelphia: University of Pennsylvania Press, 1949.

Puiggari, Miguel. Sobre la inocuidad de los saladeros o sea la refutacion de los cargos hechos a estos establecimientos como instrumentos de insalubridad, y prueba de las preocupaciones que dominan sobre las condiciones sanitarias de las industrias analogas. Buenos Aires: Imprenta La Tribuna, 1871.

Quesada, Florencia. La modernización entre cafetales San José, Costa Rica, 1880-1930. Helsinki: Universidad de Helsinki, Instituto Renvall, 2007.

------. "Transformatión urbana y cambio socio-espacial: Ciudad de Guatemala y San José de Costa Rica, 1880-1930.” Paper presented at. Latin American Studies Association XXII International Congress. Miami, FL, 2000.

Quesada, Vicente. "La ciudad de Buenos Aires. Apuntes de una viajera.” Nueva Revista de Buenos Aires (1882). Buenos Aires: Peuser.

------. Memorias de un viejo. Escenas de costumbres de la República Argentina. Buenos Aires: Peuser, 1888.

Quinn, Naomi. "The Cultural Basis of Metaphor." In Beyond Metaphor: The Theory of Tropes in Anthropology, James W. Fernandez. Stanford: Stanford University Press, 1991.

Radovanovic, Elisa. Agua y sanamiento en Buenos Aires, 1580-1930. Buenos Aires: Patrimonio Historico, 1999.

Buenos Aires: Avenida de Mayo. Buenos Aires: Ediciones Turísitcas de Mario Banchik, 2002.

------. Buenos Aires: Ciudad Moderna, 1880-1910. Buenos Aires: Ediciones Turisticas de Mario Banchik, 2002.

Rawson, Guillermo. Conferencias sobre higiene pública dadas en la facultad de medicina de Buenos Aires. Paris: Donnamette and Hattu, 1876.

------ "Escritos y discursos del Dr. Guillermo Rawson.” Compiled and edited by Alberto B. Martínez. Buenos Aires: Compañia Sud-Americana de Billetes de Banco, 1891.

------. "Estudio sobre las casas de inquilinato en Buenos Aires." In Escritos y discursos, compiled and edited by Alberto B. Martínez. Buenos Aires: Sudamericana de Billetes de Banco, 1891.

Reber, Vera Blinn. "Blood, Coughs, and Fever: Tuberculosis and the Working Class of Buenos Aires, Argentina 1885-1915." Social History of Medicine 12, no. 1 (February 1999): 4179.

------. “The Demographics of Paraguay: A Reinterpretation of the Great War, 1864-70.” Hispanic American Historical Review 68, no. 2 (May 1988): 289-319. 
-----. "Misery, Pain, and Death: Tuberculosis in Nineteenth-Century Buenos Aires." The Americas 56, no. 4 (April 2000): 497-528.

Recalde, Héctor. Las epidemias de cólera (1856-1895): Salud y sociedad en la Argentina oligárquica. Buenos Aires: Corregidor, 1993.

------. La salud de los trabajadores en Buenos Aires (1870-1910). Buenos Aires: Grupo Editor Universitario, 1997.

Reff, David T. Disease, Depopulation, and Culture Change in Northwestern New Spain, 15181764. Salt Lake City: University of Utah Press, 1991.

Reill, Peter Hans. The German Enlightenment and the Rise of Historicism. Berkeley: University of California Press, 1975.

Ricoeur, Paul. "The Metaphorical Process as Cognition, Imagination, and Feeling." Critical Inquiry 5 (1978): 143-59.

-----. The Rule of Metaphor: Multi-disciplinary Studies of the Creation of Meaning in Language. Translated by Robert Czerny. Toronto: University of Toronto Press, 1977.

Rigau-Pérez, José G. "The Introduction of Smallpox Vaccine in 1803 and the Adoption of Immunization of Government Function in Puerto Rico." Hispanic American Historical Review 69, no. 3 (August 1989): 393-423.

Roca, Lourdes, and Fernando Aguayo. "Usos y apropricaiones de un espacio urbano: el paseo del Zócalo, 1880-1885.” Secuencia 59 (May-August 2004): 103-28.

Rock, David. Argentina, 1516-1987: From Spanish Colinization to Alfonsin. Berkeley: University of California Press, 1985.

Rodriguez, Julia. Civilizing Argentina: Science, Medicine, and the Modern State. Chapel Hill: University of North Carolina Press, 2006.

Rojas, Ricardo. La restauración nacionalista. Buenos Aires: Peña Lillo, 1909.

Romero, José Luis. A History of Argentine Political Thought. Translated by Thomas F. McGann. Stanford, California: Stanford University Press, 1963.

Roncador, Sonia. "O demônio familiar: Lavadeiras, amas-de-leite e criadas na narrativa de Júlia Lopes de Almeida." Luso-Brazilian Review 44, no. 1 (2007): 91-119.

Roniger, Luis and Tamar Herzog, eds. The Collective and the Public in Latin America: Cultural Identities and Political Order. Brighton: Sussex Academic Press, 1988.

Rosenthal, Anthon. "Spectacle, Fear, and Protest: A Guide to the History of Urban Public Space in Latin America." Social Science History 24, no. 1 (2000): 33-73.

Rosenzweig, Roy, and Elizabeth Blackmar. The Park and the People: A History of Central Park. Ithaca, NY: Cornell Universtiy Press, 1992.

Rosetti, Carlos. "El Buenos Aires neuevo. La ciudead de piedra y la ciudad de flores." Arquitectura 23 (May 1905). 
Rothfels, Nigel. "Savages and Beasts: The Birth of the Modern Zoo." In Animals, History, Culture, edited by Harriet Ritvo. Baltimore: Johns Hopkins University Press, 2002.

Ruggiero, Kristin. "Honor, Maternity, and the Disciplining of Women: Infanticide in Late Nineteenth-Century Buenos Aires." Hispanic American Historical Review 72, no. 3 (1992): 353-73.

------. Modernity in the Flesh: Medicine, Law, and Society in Turn-of-the-Century Argentina. Stanford: Stanford University Press, 2004.

Ruiz Moreno, Leandro. La peste histórica de 1871: Fiebre amarilla en Buenos Aires y Corrientes. Paraná, Argentina: Nueva Impresora, 1949.

Russo, Horacio. "Los espacios verdes públicos de la ciudad de Buenos Aires: su evolución histórica 1580-1899." Unpublished master's thesis. Buenos Aires: Facultad de Agronomía de la Universidad de Buenos Aires, 1968.

Sacks, Sheldon, ed. On Metaphor. Chicago: University Chicago Press, 1979.

Salessi, Jorge. Médicos maleantes y maricas. Higiene, criminología, y homosexualidad en la construcción de la nación Argentina (Buenos Aires: 1871-1914). Buenos Aires: Beatríz Viterbo Editora, 1995.

Salvatore, Ricardo D. "The Normalization of Economic Life: Representation of the Economy in Golden-Age Buenos Aires, 1890-1913.” Hispanic American Historical Review 81, no. 1 (February 2001): 1-44.

Sargent, Charles S. The Spatial Evolution of Greater Buenos Aires, 1870-1930. Tempe: Arizona State University, 1974.

Sarmiento, Domingo F. “Arquitectura doméstica.” In Obras completas, edited by A. Belin Sarmiento. Buenos Aires: Imprenta y Litografía Mariano Moreno, 1900.

------. Barbarism and Civilization. Life in the Argentine Republic in the Days of the Tyrants. New York: Hafner Press, 1868.

-----. "Discurso inaugural del Parque 3 de Febrero." In Obras completas. Buenos Aires: Editorial Luz del Dia.

-----.. “Exposición Agricola.” In Obras completas. Buenos Aires: Editorial Luz del Dia.

-----. “El proceso de Rosas.” In Obras Completas. Buenos Aires: Editorial Luz del Dia.

Sábato, Hilda. "Citizenship, Political Representation and the Formation of the Public Sphere in Buenos Aires, 1850s-1880s." Past and Present 136 (1992): 139-63.

------. Entre el voto y la movilización, Buenos Aires 1862-1880. Buenos Aires: Sudamericana, 1998.

Scenna, Míguel Angel. Cuando murió Buenos Aires, 1871. Buenos Aires: Ediciones La Bastilla, 1974. 
Schell, Patience A. "Nationalizing Children Through Schools and Hygiene: Porfirian and Revolutionary Mexico City.” The Americas 60, no. 4 (April 2004): 559-87.

Scherrer, Jacobo. "Estudios sobre la fiebre amarilla del año 1871." Biblioteca de la Facultad de Medicina: Universidad de Buenos Aires, 1872.

Schultz, Kirsten. "Royal Authority, Empire and the Critique of Colonialism: Political Discourse in Rio de Janeiro (1808-1821).” Luso-Brazilian Review 37, no. 2 (Winter 2000): 7-31.

Scobie, James R. "Buenos Aires as a Commercial-Bureaucratic City, 1880-1910: Characteristics of a City's Orientation." American Historical Review 77, no. 4 (October 1972): 1035-73.

-----. Buenos Aires: From Plaza to Suburb, 1870-1910. New York: Oxford University Press, 1974.

Scott, James C. Weapons of the Weak: Everyday Forms of Peasant Resistance. New Haven: Yale University Press, 1985.

Shi, Mingzheng. "From Imperial Gardens to Public Parks: The Transformation of Urban Space in Early Twentieth-Century Beijing." Modern China 24, no. 3 (July 1998): 219-54.

Shimko, Keith L. "Metaphors and Foreign Policy Decision Making." Political Psychology 15, no. 4 (December 1994): 655-71.

Shumway, Jeffrey M. The Case of the Ugly Suitor and Other Histories of Love, Gender, and Nation in Buenos Aires, 1776-1870. Linoln: University of Nebraska Press, 2005.

Silva Di Liscia. "Marcados en la piel: Vacunación y viruela en Argentina (1870-1910)." Ciência \& Saúde Coletiva 16, no. 2 (February 2011).

Slatta, Richard W. "Pulperías and Contraband Capitalism in Nineteenth-Century Buenos Aires." The Americas 38 (January 1982): 347-62.

Sontag, Susan. Illness as Metaphor. New York: Farrar, Straus and Giroux, 1978.

Sparrach, Eduardo. "Eduardo Ladislao Holmberg: Médico y Naturalista." Fundación Cultural Santiago del Estero (2007).

Stepan, Nancy. "The Interplay Between Socio-Economic Factors and Medical Science: Yellow Fever Research, Cuba and the United States." Social Studies of Science 8, no. 4 (November 1978): 397-423.

Stepan, Nancy Leys. "The Hour of Eugenics": Race, Gender, and Nation in Latin America. Ithaca, NY: Cornell University Press, 1991.

-----. "The Only Serious Terror in These Regions': Malaria Control in the Brazilian Amazon." In Disease in the History of Modern Latin America: From Malaria to AIDS, edited by Diego Armus, 25-50. Durham, NC: Duke University Press, 2003.

Stern, Alexandra Minna. "Buildings, Boundaries, and Blood: Medicalization and Nation-Building on the U.S.-Mexico Border, 1910-1930." Hispanic American Historical Review 79, no. 1 (February 1999): 41-81. 
Sternberg, R. Intelligence, infomation processing, and analogical reasoning. Hillsdale: Lawrence Erlbaum Associates, 1977.

Suriano, Juan. La huelga de inquilinos de 1907. Buenos Aires: Centro Editorial de América Latina, 1983.

Swiggers, Pierre. "Cognitive Aspects of Aristotle's Theory of Metaphor." Glotta 62 (1984): 4045.

Szuchman, Mark D. "Childhood Education and Politics in Nineteenth-Century Argentina: The Case of Buenos Aires." Hispanic American Historical Review 70, no. 1 (February 1990): 109-38.

------. "Constructing the City, Constructing the State: Architecture and Political Transition in Urban Argentina, 1810-1860." In State and Society in Spanish America During the Age of Revolution, edited by Victor M. Uribe-Uran, 193-218. Wilmington, Delaware: Scholarly Resources Inc., 2001.

-----. Order, Family, and Community in Buenos Aires: 1810-1860. Stanford: Stanford University Press, 1988.

Talmon, J. L. The Origins of Totalitarian Democracy. New York: Praeger, 1960.

Tenorio Trillo, Mauricio. "1910 Mexico City: Space and Nation in the City of the Centenario." Journal of Latin American Studies 28, no. 1 (February 1996): 75-104.

Trifilo, S. Samuel. "Buenos Aires as Seen by British Travelers, 1810-1860.” The Americas 15, no. 1 (July 1958): 37-59.

Trigo, Benigno. "Crossing the Boundaries of Madness: Criminology and Figurative Language in Argentina (1878-1920).” Journal of Latin American Cultural Studies 6, no. 1 (1997): 720 .

------. Subjects of Crisis: Race and Gender as Disease in Latin America. Middletown, Conn.: Wesleyan University Press, 2000.

------. Subjects of Crisis: Race and Gender as Disease in Latin America. Hanover, NH: University Press of New England, 2000.

Trueba Lara, José Luis. Masones en México: Historia del poder oculto. Mexico, D.F.: Grijalbo, 2007.

Tuan, Yi-Fu. "Sign and Metaphor." Annals of the Association of American Geographers 68 (1978): 363-72.

Tulio Halperín Donghi. José Hernandez y sus mundos. Buenos Aires: Editorial Sudamericana: Instituto Torcuato di Tella, 1985.

Uribe-Uran, Victor M. "The Birth of a Public Sphere in Latin America During the Age of Revolution." Comparative Studies in Society and History 42, no. 2 (April 2000): 425-57.

------. "The Enigma of Latin American Independence: Analyses of the Last Ten Years." Latin American Research Review 32, no. 1 (1997): 236-55. 
V, E. de, L. B., and M. R. Los saladeros y la fiebre amarilla. Pamphlet. Buenos Aires: Imprenta del Porvenir, 1871.

Vacarezza, Oscar. "recordación de los médicos y practicantes caídos durante la epidemia de fiebre amarilla de 1871." Boletín Archivo Nacional de Medicina 49, no. 2 (1971).

van Dülmen, Richard. "Die Aufklärungsgesellschaften in deutschland als Forschungsproblem." Francia 5 (1977): 251-75.

------. The Society of the Enlightenment: The Rise of the Middle Class and Enlightenment Culture in Germany. Cambridge: Polity, 1992.

Veltre, Thomas. "Manageries, Metaphors, and Meanings." In New Worlds, New Animals, From Menagerie to Zoological Park in the Ninteenth Centrury, edited by R.J. Hoage and William A. Davies. Baltimore, 1996.

Vitali, Olga. "El primer zoológico de Buenos Aires.” Todo es Historia 19 (September 1986): 3841.

Vosniadou, Stella, and Andrew Ortony. Similarity and Analogical Reasoning. New York: Cambridge University Press, 1989.

Wakild, Emily. "Naturalizing Modernity: Urban Parks, Public Gardens and Drainage Projects in Porfirian Mexico City." Estudios Mexicanos 23, no. 1 (Winter 2007): 101-23.

Whtimore, Thomas M. Disease and Death in Early Colonial Mexico: Simulating Amerindian Depopulation. Boulder, CO: Westview Press, 1992.

Wilde, Eduardo. El hipo. Buenos Aires: La Cultura Argentina, 1924.

-----. Obras completas. Buenos Aires: Peuser, 1917.

Wilde, Eduardo, and Pedro Mallo. "La Memoria de la Junta de Sanidad del Puerto Central Correspondiente a 1871."

Yujnovsky, Oscar. "Del conventillo a la villa miseria.” In Buenos Aires de historia de cuatro siglos, edited by José Luis Romero and Luis Albert Romero. Buenos Aires: Editorial Abirl, 1898.

------. "Políticas de vivienda en la ciudad de Buenos Aires (1880-1914)." Desarollo Económico 14, no. 5 (Julio-Septiembre 1974): 321-71.

Zaida Lobato, Mirta. Política, médicos y enfermedades: Lecturas de historia de la salud Argentina. Buenos Aires: Editorial Biblos, 1996.

Zinny, Antonio. "El cólera morbo no es nuevo en el Río de la Plata." Revista de Buenos Aires 47 (March 1867): 468-80.

Zulawski, Ann. "Hygiene and 'The Indian Problem': Ethnicity and Medicine in Bolivia, 19101920." Latin American Research Review 35, no. 2 (2000): 107-29. 
VITA

Kindon Meik

\section{EDUCATION}

M.A. in International and Area Studies, Brigham Young University, 1999

B.A. in International Relations, Brigham Young University, 1996

\section{PROFESSIONAL EXPERIENCE}

Interim City Manager/Community Development Director, City of Corcoran, CA, 2011present

Assistant City Manager, City of Lindsay, CA, 2007-2011

Director of Personnel, City of Lindsay, CA, 2006-2011

Community Development Analyst, City of Lindsay, CA, 2003-2006

Lecturer, Department of History, California State University Bakersfield, 2003-2004

Adjunct Faculty, Division of Social Science, Porterville College, 2003-2004

Teaching Assistant, Department of History, Florida International University, 1999-2002

Assistant to the Director, GEAR UP and Enlace Programs, Florida International

University, 2000-2002

Teacher, Lindsay High School, Lindsay, CA, 1997-1999

Student Adviser, David M. Kennedy Center, Brigham Young University, 1996-1997

\section{FELLOWSHIPS AND GRANTS}

Fulbright Fellow, Department of State, 2002-2003

Graduate Assistantship, Department of History, Florida International University, 19992002 
Graduate Assistantship, David M. Kennedy Center, Brigham Young University, 19961997

BOARDS AND PROFESSIONAL ASSOCIATIONS

Community Development Block Grant, Advisory Board, 2010-2011

Vice President of the Board, Lindsay Chamber of Commerce, 2006-2011

Member, Lindsay Health Care Advisory Committee, 2009-2011

Volunteer Leader, Boy Scouts of America

HONORS AND AWARDS

Rotary Exchange Student, 1989-1990

Eagle Scout, 1987

\section{CONFERENCE PRESENTATIONS AND LECTURES}

"Case Studies on Community Development," National Association of Latino Elected and Appointed Officials, Washington, D.C., 2010

"Contested Space and Contested Voices: The Hygienist Movement in Buenos Aires, 1871-1910,” History Forum, California State University Bakersfield, 2003

"Buenos Aires y la higiene. El discurso reformista del periodismo a fines del siglo XIX," Simpósio Ciencia, Salud y Poder en América Latina y el Caribe, XXI International Congress of History and Science, Mexico City, 2001 